Universidade de Brasília

Faculdade de Educação Física

Programa de Pós-Graduação em Educação Física

Mestrado em Educação Física

EDUCAÇÃO FÍSICA E FORMAÇÃO HUMANA: CONTRIBUIÇÕES PARA O DEBATE A PARTIR DA INTERLOCUÇÃO COM A ONTOLOGIA DO SER SOCIAL DE GYORGY LUKÁCS

Carolina Leocádio Alves

BRASÍLIA 
CAROLINA LEOCÁDIO ALVES

EDUCAÇÃO FÍSICA E FORMAÇÃO HUMANA: CONTRIBUIÇÕES PARA O DEBATE A PARTIR DA INTERLOCUÇÃO COM A ONTOLOGIA DO SER SOCIAL DE GYORGY LUKÁCS

Dissertação apresentada ao Programa de Pós-Graduação em Educação Física da Universidade de Brasília (UnB), na área de Estudos Sociais e Pedagógicos da Educação Física, Esporte e Lazer, vinculada à área de Atividade Física e Esporte, como requisito parcial à obtenção do título de mestre em Educação Física.

Orientador: Prof. Dr. Édson Marcelo Húngaro.

BRASÍLIA 


\title{
EDUCAÇÃO FÍSICA E FORMAÇÃO HUMANA: CONTRIBUIÇÕES PARA O DEBATE A PARTIR DA INTERLOCUÇÃO COM A ONTOLOGIA DO SER SOCIAL DE GYORGY LUKÁCS
}

\author{
Dissertação apresentada ao Programa de Pós-Graduação \\ em Educação Física da Universidade de Brasília (UnB), \\ na área de Estudos Sociais e Pedagógicos da Educação \\ Física, Esporte e Lazer, vinculada à área de Atividade \\ Física e Esporte, como requisito parcial à obtenção do \\ título de mestre em Educação Física. \\ Orientador: Prof. Dr. Édson Marcelo Húngaro.
}

Defendida e aprovada em: 09/12/2015.

\section{COMISSÃO EXAMINADORA}

Prof. Dr. Edson Marcelo Húngaro - Presidente

Universidade de Brasília (UnB)

Prof. Dr. Pedro Fernando Avalone Athayde - Titular

Universidade de Brasília (UnB)

Prof. Dr. Tadeu João Ribeiro Baptista - Titular

Universidade Federal de Goiás (UFG)

Prof. Dr. Fernando Mascarenhas Alves - Suplente

Universidade de Brasília (UnB) 
Ficha catalográfica elaborada automaticamente, com os dados fornecidos pelo(a) autor(a)

AAL474e

Alves, Carolina Leocádio
Educação Física e formaço humana: contribuições para
o debate a partir da interlocução com a ontologia do
ser social de Gyorgy Lukács / Carolina Leocádio
Alves; orientador Edson Marcelo Húngaro. -- Brasilia,
2015.
146 p.
Dissertação (Mestrado - Mestrado em Educação Física)
-- Universidade de Brasiliia, 2015 .
1. Ontologia do ser social. 2. Formação humana. 3. Educação
Física. I. Húngaro, Édson Marcelo, orient. II. Título.


Dedico aos meus pais, João e Divina, e ao meu irmão, João Paulo. São essenciais na minha vida e, nesse período de formação, foram a pedra angular da minha força, persistência e fé em mim mesma. Eu amo vocês! 
Crendo na presença de um Deus maior em sua infinita bondade, agradeço exaustivamente a todos aqueles que, direta e indiretamente, contribuíram para a realização deste sonho. Pessoas que me fazem acreditar que posso fazer a diferença a partir de minha intervenção pedagógica na escola, espaço onde quero concentrar minhas forças e energia na luta por um mundo melhor. Mais do que um aprimoramento acadêmico e profissional, termino este mestrado convicta de que, embora repleta de contradições, estou mais humana.

Muito obrigada! 
O homem, no entanto, não é apenas um ser natural, mas ser natural humano, isto é, um ser que é para si próprio e, por isso, ser genérico, que enquanto tal deve atuar e confirmar-se tanto em seu ser como em seu saber. Por conseguinte, nem os objetos humanos são os objetos naturais tais como se oferecem imediatamente, nem o sentido humano, tal como é imediata e objetivamente, é sensibilidade humana, objetividade humana. Nem objetiva nem subjetivamente está a natureza imediatamente presente ao ser humano de modo adequado. E como tudo que é natural deve nascer, assim também o homem possui seu ato de nascimento: a história, que, no entanto, é para ele uma história consciente, e que, portanto, como ato de nascimento acompanhado de consciência é ato de nascimento que se supera. A história é a verdadeira história natural do homem. (MARX, 1974, p. 41; Grifos do autor) 


\section{SUMÁRIO}

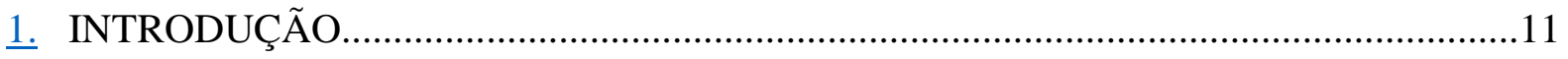

2. CAPÍTULO I - A CONCEPÇÃO MARXISTA DE HOMEM …..................................... 34

2.1. Traços fundamentais da concepção marxista de homem................................................ 45

2.1.1. A base materialista: as origens ontológicas e as condições reais de existência..........48

2.1.2. A concepção de história: a consubstanciação dos atos humanos................................56

2.1.3. O trabalho: a maneira como o homem transforma e regula a natureza .....................6 60

2.1.4. A alienação: a expropriação do homem de si mesmo e a incompatibilidade ao gênero humano. .70

3. CAPÍTULO II - LUKÁCS E OS PRINCÍPIOS ONTOLÓGICOS FUNDAMENTAIS DE MARX .78

4. CAPÍTULO III - ONTOLOGIA E EDUCAÇÃO: ACERCA DA PEDAGOGIA

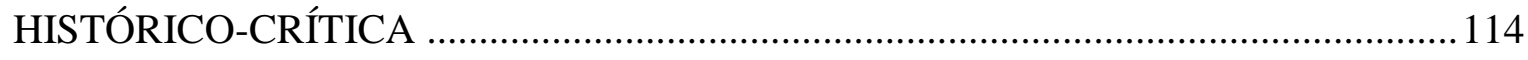

4.1. Contextualização histórica da Pedagogia Histórico-Crítica ...................................... 118

4.2. Contextualização teórica da Pedagogia Histórico-Crítica ......................................... 127

4.3. A Pedagogia Histórico-Crítica e a formação humana .............................................. 131

5. CAPÍTULO IV - CONSIDERAÇÕES FINAIS ....................................................... 139

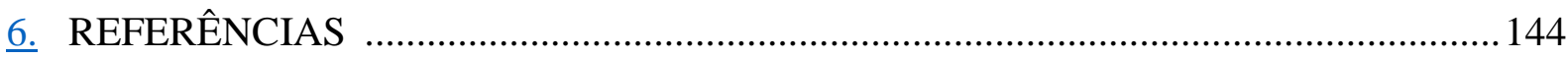




\section{RESUMO}

Esta pesquisa procurou estudar as contribuições de Marx e Lukács - com ênfase neste último - para as formações humana e acadêmico-científica em Educação Física. A ênfase recaiu, especialmente, na ontologia do ser social de Lukács. Objetivou-se conjecturar sobre as possibilidades entre Lukács e sua ontologia para a análise da formação humana, bem como suas mediações com a Educação Física. Os procedimentos metodológicos estruturados para realizar essa investigação científica foram baseados na revisão de literatura das obras de Marx e Lukács. Conclui-se, a partir do que foi intentado inicialmente, que o trabalho educativo realizado pela Educação Física é parte constituinte da formação humana indo além de uma simples significação de educação do corpo quando, na verdade, trata-se da educação de homens.

Palavras-chave: Ontologia do ser social; Formação humana; Educação Física. 


\begin{abstract}
This research sought to study the contributions of Marx and Lukács - with emphasis in the latter - to the formations of human and academic-scientific Physical Education. The emphasis fell particularly on the ontology of the social being of Lukács. The objective was to conjecture about the possibilities between Lukács and its ontology to the analysis of human formation, as well as their mediations with the Physical Education. The methodological procedures are structured to accomplish this scientific research were based on a literature review of the works of Marx and Lukács. It can be concluded, from what was intended initially, that the educational work conducted by the Physical Education is a constituent part of the human formation going beyond a simple signification of the education of the body when, in fact, it is the education of men.
\end{abstract}

Key-words: The ontology of the social being; Human formation; Physical Education. 


\section{INTRODUÇÃO}

Desde o ingresso no mestrado, inicialmente a intenção era a de apreender as implicações das relações de trabalho do modo de produção capitalista no corpo, sob a inspiração da ontologia social de Lukács.

Tal intencionalidade se justificava pela importância de sistematizar o conhecimento sobre a problemática levantada, para adensar o esforço colaborativo de proposição de mudanças, ou seja, numa inspiração emancipatória (revolucionária). Um trabalho comprometido com um projeto emancipador, necessariamente, deve, enquanto houver capitalismo, fundar-se nas elaborações de Marx. Em nosso caso, dentro de nossas limitações, intentamos uma apropriação desse importante autor, porém, sob a perspectiva de um de seus intérpretes: Lukács.

Supondo Karl Marx e Gyorgy Lukács como supostos necessários para a análise do ponto de vista formal, houve a necessidade de utilizarmos procedimentos investigativos de uma pesquisa exploratória de caráter bibliográfico, revisando as obras desses autores, para se alcançar os objetivos esperados.

No decorrer do mestrado, essa intenção inicial foi se modificando em razão da trajetória e das disciplinas cursadas (abaixo listadas). Em cada uma delas, pontuamos o que foi ensinado e incorporado como enriquecimento teórico, sendo válido aquilo que era interessante como formação humana e acadêmica, e para o desenvolvimento do trabalho de dissertação.

Teoria Social, Pós-Modernidade e Educação Física (prof. Dr. Edson Marcelo Húngaro): o processo de constituição da teoria social de Marx; o quadro de transformações sociais recentes do qual emerge a agenda pós-moderna; os supostos teóricos que sustentam a agenda pós-moderna e as temáticas trazidas por ela; os impactos da agenda pós-moderna sobre as produções da Educação e da Educação Física; as respostas iniciais ao avanço da agenda pós-moderna nos âmbitos da Educação e da Educação Física.

Métodos e Técnicas de Pesquisa em Educação Física Aplicados às Ciências Sociais (profa. Dra. Dulce Maria Filgueira de Almeida): o campo acadêmico-científico da Educação Física; reflexões teóricas sobre o conhecimento científico; métodos e técnicas 
de investigação científica; uso e aplicabilidade do instrumental na pesquisa em Educação Física.

Sociologia do Trabalho (profa. Dra. Lucinéia Scremin Martins): a centralidade do trabalho como categoria de análise; crítica marxista ao processo de trabalho no capitalismo; Braverman e Burawoy; setor informal; trabalho e não-trabalho; efeitos da globalização; terceirização; fordismo e pós-fordismo.

Políticas de Esporte e Lazer (prof. Dr. Fernando Mascarenhas Alves): relações entre Estado e sociedade civil; discussões conceituais em políticas públicas e política social; discussões conceituais em esporte, lazer, política e direitos sociais; fundamentos sóciohistóricos da política social no Brasil; estrutura e funcionamento das políticas de esporte e lazer no Brasil; avaliação de ações e programas de esporte e lazer; a pesquisa e a produção acadêmica em políticas de esporte e lazer; temas emergentes em políticas de esporte e lazer.

Seminários de Estudos Sociais e Pedagógicos da Educação Física, Esporte e Lazer (prof. Dr. Ari Lazzarotti Filho): aspectos históricos da constituição do campo acadêmicocientífico da Educação Física; os conceitos de habitus, campo e capital em Bourdieu; identificação dos principais agentes, instituições e capitais do campo da Educação Física; o modus operandi da produção do conhecimento na Educação Física brasileira.

Como resultado desta trajetória, chegamos a esta pesquisa, que procurou estudar as contribuições de Marx e Lukács - com ênfase neste último - para as formações humana e acadêmico-científica em Educação Física. A ênfase recaiu, especialmente, na ontologia do ser social, de Lukács, e nas explicações a respeito do que são os homens e o mundo e da centralidade ontológica do trabalho para essa compreensão. Buscamos, então, nessa tarefa interpretativa, conjecturar sobre as possibilidades entre Lukács e sua ontologia para a análise da formação humana, bem como suas mediações com a Educação Física.

O interesse por esse objeto origina-se de conquistas e pequenos avanços obtidos pelo acesso e aprendizado de parte do arcabouço teórico-metodológico do referencial marxista, ao longo do desenvolvimento de estudos acadêmicos. Nessa ocasião, as aflições geradas e as 
sínteses construídas foram direcionadas para a reflexão acerca da condição humana em seus princípios ontológicos, e da realização da humanização e da adequação ao gênero.

O adensamento teórico em Marx e Lukács, durante o processo investigativo, trouxe subsídios expressivos e indispensáveis para se refletir sobre os processos formativos na Educação Física e os fundamentos ontológicos que os respaldam. Mas não foi fácil, pois, em uma dimensão social, essas temáticas podem ser desafiadoras ao menos por duas razões.

A primeira pelo fato de que é inconcebível, nos dias atuais, a concretização de uma formação acadêmico-científica (inicial e/ou continuada) que desconheça a formação humana em sua totalidade e que não esteja voltada para contornos exclusivos de uma formação emancipadora. Isso tudo em circunstâncias nas quais o ser social "formado" atuará em determinada área do mundo do trabalho, o da Educação Física. Rechaça-se a "pseudo formação", que tende a ofertar apenas o conhecimento pragmático do específico da atuação do professor de Educação Física com prioridade para as requisições do mercado de trabalho.

Ignorar e negar a importância dos fundamentos ontológicos nos processos formativos é inviabilizar a assimilação do suporte teórico necessário para que o indivíduo assuma uma postura revolucionária em suas práticas sociais perante a sociabilidade capitalista. Ao mesmo tempo, é também danificar a instrumentalização da práxis educativa do professor para a promoção de uma intervenção mais consciente e transformadora na sua realidade, ampliando as mediações que ele possa arranjar em seu papel de formador de outras consciências.

A segunda razão se dá na medida em que as contribuições enriquecem as mediações que perpassam as fronteiras da produção científica. A ciência possui importantes interferências a serem feitas, tanto no sentido de distinguir os delineamentos da formação em sua (s) concepção (ões) e limite (s) como também de operar mudanças estruturais e de conteúdo no processo formativo, focando os fundamentos ontológicos do ser social. É, pois, um fazer científico compromissado com o social e o político.

Para tanto, muito mais do que produzir conhecimentos científicos sobre determinados setores da realidade, é fundamental que a ciência se questione sobre o que tem produzido e que se proponha a colocar em xeque suas próprias objetivações, principalmente em função do impacto ideológico que elas ostentam no desenvolvimento social. Tem-se, portanto, a oportunidade de se sanar, numa perspectiva analítica que é ontológica, histórica e materialista, possíveis ausências, incipiências e erroneidades nas discussões epistemológicas e nas produções científicas que elegem a formação como tema de pesquisa.

Afirmar que essas razões tornam essa empreitada desafiadora supõe, entre outras coisas, o juízo de que elas podem ser organizadas como estratégias políticas. Não são ações 
isoladas que têm a finalidade de dar respostas às demandas sociais e históricas atuais de maneira altruísta ou reformas parciais no horizonte do capitalismo. São, por outro lado, peças de um "quebra-cabeça" maior de lutas sociais anticapitalistas e da construção de uma sociabilidade radicalmente livre e verdadeiramente emancipada. A formação do ser social e a ciência são mediações essenciais para a materialização do processo de emancipação e devem estar empenhadas com a liberdade e a busca da felicidade dos seres humanos. Qualificar a formação dos indivíduos sociais e valorizar a aplicabilidade da ciência para com as necessidades estritamente humanas é resistir e abdicar do fato de que a lógica do capital e da propriedade privada seja a responsável pela história da humanidade, reafirmando o papel histórico que caberia ao proletariado e munindo-o com a "arma da crítica".

É uma intensa e multifacetada luta de ideias, porque este movimento no campo das ideias deve se desenvolver dando suporte para mudanças qualitativas na história concreta da sociedade. Assim, ele pode se transformar em força material. O tempo histórico, que por enquanto acomete o ser social, dá sinais do quanto é imprescindível a formação de indivíduos humano-sensíveis que se sensibilizem com as condições de existência de seus iguais. E, claro, esses indivíduos passariam a lutar em desfavor das contradições e da reprodução das tragédias e desgraças dos homens. Não deve ser entendida como da "natureza humana" a perseguição da felicidade através da miséria alheia.

Diante disso, tendo arrolado essas considerações de cunho social, torna-se evidente que são indissociáveis da análise daquilo que permeia esse objeto de estudo. Marx e Lukács fornecem elementos que condicionam progressos no exercício da ciência. Eles prestam grandes esclarecimentos do movimento do real no plano ontológico da compreensão da essência humana, da constituição do ser social e do processo de trabalho. A priori, é inexorável que se determine o que os homens são e como eles se constituem para, então, definir os modos de como e, sobretudo, para que formá-los.

Numa abordagem ontológica da ciência, admite-se que ela seja uma mediação para a efetivação da práxis humana, quando do impulso para o conhecimento do real. Daí procede a problematização das objetivações científicas desenvolvidas em relação, principalmente, às suas determinações e materialidade. E, ao defender uma maneira de se posicionar crítica e conscientemente, rebatendo, pois, a falsa ideia de neutralidade e de que a ciência não pode agregar um caráter político no acirramento da luta de classes, as inquietações destacadas são em prol de uma ingerência que recuse a dinâmica cega e totalizante que o capital, em sua lógica, empresta à ideologia predominante. Essa ingerência ainda favorece a redução da 
ciência a mero instrumento para intensificação da exploração da força de trabalho e da deformação de consciências.

Nesse sentido da prática da ciência, Marx também ganha grande visibilidade ao construir uma teoria da história viabilizando o desenvolvimento da epistemologia moderna com a estruturação de um método mais avançado e legítimo de conhecimento. Para além da descoberta das intenções ideológicas das ideias hegemônicas, o processo de produção do conhecimento deve incidir no entendimento dos novos fenômenos complexos de múltiplas determinações produzidas na realidade objetiva. E isso só é possível por uma teoria crítica da história e da sociedade que seja capaz de explicar as leis gerais e as particularidades do tempo atual. Com sua concepção metodológica, Marx oferece recursos instrumentais para a revelação das contradições postas pela formação social burguesa.

Portanto, o entendimento é de que todo e qualquer tipo de formação é uma questão ontológica decisiva. Pensar o sentido e o significado da formação do ser social, seja numa dimensão mais geral, como no caso da humanização e da adequação ao gênero humano, ou em uma mais restrita tal qual a atmosfera da Educação Física para o mundo do trabalho, parte do pressuposto da análise de quais são os fundamentos que estão sendo estruturados para a formação desse sujeito e quais os resultados que se anseia ter como fim.

Como o sujeito em questão é o ser social, cabe a importância de se considerar a afirmação do que ele é e de como se constitui em seu permanente movimento de objetivação. É preciso ter em vista o determinado modelo de sociabilidade no qual ele interferirá por meio da consubstanciação de seus atos singulares. Trata-se do pôr teleológico transformador da realidade na condição de humanos: produtos sociais no desenvolvimento histórico que está condicionado pela maneira como a vida material é produzida socialmente na complexa rede de conexões que os homens estabelecem entre si.

Dadas as legendas sociais mais prioritárias sob o olhar de uma sociedade baseada na divisão de classes, essa condição deve estar articulada à tarefa histórica de se superar o modo de produção vigente junto ao modelo societário que ele requer para sua reprodução. Isso junto à exigência, por parte de quem se alinha a essa tarefa, de um posicionamento explícito perante a luta de classes.

Em função do anseio em criar mecanismos alternativos que convirjam para essa tarefa, a preocupação volta-se, então, para os fundamentos ontológicos dentre aqueles que precisam ser abarcados num processo formativo como meios fecundos de demonstração da possibilidade de emancipação humana. Minimamente, para se atingir as especificidades do ser 
social, é necessário perpassar os traços que se definem no status ontológico e que manifestam suas determinações contextualizando suas raízes objetivas.

Falar da relação entre Marx e Lukács é evidenciar como este último desvenda e desenvolve o estatuto ontológico sublinhado nas obras marxianas. Nesse estatuto, identificase a essência do indivíduo social, as mediações nas quais se pautam a constituição da generalidade humana e a potencialidade existente na realização desta essência de edificar a história usando as mãos dos homens mediadas pela ação intencional sobre a natureza no ato do trabalho. Através da interrogação de Marx sobre a essência e a constituição do ser social, é possível concretizar a cognoscibilidade de uma teoria geral do ser. Há a superação das singularidades advindas de modo puramente gnosiológico ou puramente metodológico/epistemológico. E, assim, se destaca uma série de determinações e categorias do ser social, operando uma radical heterogeneização de todos os seres no plano ontológico.

Ao colaborar para o esclarecimento das bases filosóficas sólidas do ser social, a ontologia de Lukács expõe uma clara intenção revolucionária e vem ao encontro do projeto de emancipação humana, inicialmente proposto por Marx (LESSA, 1996; 2012). Ela exibe avanços em dois âmbitos: 1) são demonstradas possibilidades outras no plano ontológico de superação da sociabilidade burguesa; 2) e são trazidas concepções e mediações que podem auxiliar na ruptura com os ranços e as contradições operantes na (de) formação em Educação Física. Visualizam-se contornos para ela por uma visão mais ampliada e crítica com a perspectiva do que o mundo dos homens realmente é, perspectivando-os em sua totalidade.

Lukács exerce grande influência, visto que seus textos póstumos são bastante atuais, colocando-o como um dos mais célebres críticos marxistas, assim como um dos filósofos mais proeminentes do século XX. Ele possui um arcabouço de escritos quantitativamente significativo e qualitativamente diferenciado “(...) entre as problemáticas que foram objeto da reflexão de Lukács nos diversos momentos por que evoluiu a sua obra" (PAULO NETTO, 1981, p. 29).

De acordo com Paulo Netto (1981), a importância de um complexo filosófico está no seu potencial de estabelecer pontes conectivas entre as respostas colocadas às determinadas circunstâncias sócio-históricas e também na ampliação por meio de novos nexos e mediações dos problemas levantados e suas soluções plausíveis. Estas serão congregadas ao complexo ideológico-cultural mais abrangente acumulado em que se situam e do qual são sucessoras. Desse modo, 
(...) a relevância de uma configuração filosófica implica diretamente a sua capacidade em recolher os problemas específicos de uma época dada e submetê-los a um tratamento crítico apto a deles extrair uma significação que supera o quadro factual imediato em que emergem. Isto é: um conjunto de ideias é tanto mais dotado de transcendência histórica quanto mais profundamente penetra a essência do hic et nunc. Eis porque a modalidade pela qual uma reflexão aborda sua temporalidade só se legitima enquanto, sem dissolver as especificidades com que se defronta, assimila-as ao eixo cultural pertinente à evolução sócio-humana como evolução genérica-universal. (PAULO NETTO, 1981, p. 25)

Assim como ocorre com Marx, essas condições compatibilizam as elaborações analíticas lukacsianas com as necessidades teóricas postas e identificadas por esse autor nas situações reais do seu tempo. Portanto, “(...) a obra de Lukács se converteu num diálogo crítico incessante com o que de mais significativo ocorreu no debate teórico deste século, sendo, também por isso, portadora de uma universalidade que o torna um pensador atípico em nossa época" (LESSA, 2012, p. 187).

Lukács colabora, sobretudo, para estrutura categorial do plano ontológico do ser social. Sua relevância se dá em função da forma peculiar de abordagem com a qual ele examina criticamente a ontologia humana. Traz o que é nuclear para o ser social com a tendência para a saturação de algumas de suas determinações e de questões decisivas das principais categorias.

Ao falar de determinada teoria ontológica, Lukács avança nas discussões feitas, tanto no interior da linha marxista, pois esse assunto se encontrava atrofiado no marxismo, como também no que se refere ao pensamento filosófico, no qual se articulavam os mais diversos eixos ontológicos da metafísica tradicional. A originalidade da ontologia apresentada por Lukács está em duas medidas: é, simultaneamente, uma ruptura e uma continuidade da tradição filosófica porque ele não ignora o que foi feito por esta última e introduz uma fase da produção lukacsiana posterior a 1930.

A preocupação inovadora com a qual ele se ocupa do ser social se torna primordial na proporção em que intensifica a reflexão filosófica acerca da problemática da apreensão da forma concreta de ser humano. Ou seja, se aproxima do que os homens são e de como eles se constituem, e da relação do homem (em âmbitos de sua individualidade e de ser genérico) com sua própria história (novamente individual e coletiva) quanto com a história do gênero.

Essa investida das pesquisas de Lukács acontece pela elaboração de uma proposta de recuperação de Marx que pudesse dar um radical caráter revolucionário aos seus textos, sendo este o principal reforço dele ao referencial marxista (SILVA, 2014).

Lukács reconstrói contornos bastante específicos de uma perspectiva ontológica histórica materialista desenvolvida por ele, quando da sua assimilação de categorias analíticas 
postuladas na teoria social de Marx e na busca das possibilidades emancipatórias implicadas por ela na superação da barbárie da exploração do homem pelo homem. Conforme Lukács (2010, p. 13), “A relação com Marx é a verdadeira pedra de toque para todo intelectual que leva a sério a elucidação da sua própria concepção de mundo, o desenvolvimento social, em particular a situação atual, o seu próprio lugar nela e o seu próprio posicionamento em relação a ela". Ele elucida também o significado intelectual, social e político do envolvimento comprometido com a doutrina marxista.

\begin{abstract}
Parece-me que, no período posterior a Marx, a tomada de posição em relação ao seu pensamento deve constituir o problema central de todo pensador que leve a sério a si próprio, e que o modo e o grau com que ele se apropria do método e dos resultados de Marx determinam o seu lugar no desenvolvimento da humanidade. Esse desenvolvimento está determinado pela situação de classe, se bem que essa determinação não é rígida, mas dialética. A nossa posição na luta de classes determina amplamente o modo e o grau que assumimos o marxismo, mas, por outro lado, todo novo progresso nessa adoção nos faz aderir cada vez mais à vida e à práxis do proletariado e redunda beneficamente no aprofundamento da nossa relação com a doutrina marxista (1933). (LUKÁCS, 2010, p. 15; Grifos do autor).
\end{abstract}

Essa iniciativa levou Lukács a debater com todas as teorizações de vieses ontológicos que têm, por exemplo, o impulso de encarar as tragédias e misérias humanas como produtos resultantes de uma sina imposta por Deus, ou numa tradução laicizada dessa concepção mística. Esses produtos são encarados como resultados de uma natureza humana misteriosamente dada aos indivíduos de modo irrevogável, corroborando para a demonstração daquela como motor e agente limitador do desenvolvimento social enquanto uma constante (LESSA, 1996).

Lukács põe-se a problematizar a essência humana, porque possui suas investigações pautadas nas incursões dos gregos, passando pelos homens medievais até chegar aos pensadores modernos que abrangem Hegel como seu expoente e, posteriormente, Marx até a contemporaneidade ${ }^{1}$. Destaca-se que

Se, até Hegel, o problema era descobrir qual o limite das possibilidades de evolução da sociedade a partir da determinação de uma essência a-histórica, com Marx o problema se converte em como transformar a história humana, suas relações sociais predominantes, de modo a transformar a essência humana no sentido de possibilitar o seu pleno desenvolvimento a partir de uma nova relação, em última análise, com o desenvolvimento das forças produtivas. (LESSA, 2012, p. 206)

\footnotetext{
${ }^{1}$ Cabe ressaltar que cada uma dessas teorias de ambos os momentos é um reflexo ideológico fidedigno ao contexto restritivo que está ligado à sociedade a qual o pensador pertence e as ideologias dominantes justificam e conservam o status quo do meio social no qual foram originadas (LESSA, 2012).
} 
No primeiro momento, encontram-se as laborações que compartilham diferentes estruturas ontológicas dualistas baseadas em elementos constitucionais - a ordem cosmológica, o mundo das ideias, Deus, a "natureza" do proprietário privado burguês ou o espírito hegeliano. Nelas, a realização da historicidade do mundo dos homens é a explicação desses distintos fundamentos tidos como eternos, levando à compreensão fatalista da história. A imutabilidade da essência e a transitoriedade dos fenômenos históricos são determinações do sentido e da caracterização teleológica que a história assume diante da inviabilidade dos homens se desenvolverem mais à frente das limitações colocadas por fatores ontologicamente determinados e dados a priori. A história deixa de ser um construto dos seres sociais que não sofrem intervenções de suas ações.

Em relação ao simples ser abstrato hegeliano, Lukács (1978) registra que os alcances de uma ontologia histórico-materialista de Marx superam, numa dimensão teórico-prática, a filosofia idealista lógico-ontológica de Hegel.

\footnotetext{
Hegel foi um preparador nesse domínio, na medida em que concebeu a seu modo a ontologia como uma história; em contraste com a ontologia religiosa, a de Hegel partia de "baixo", do aspecto mais simples, e traçava uma história evolutiva necessária que chegava ao "alto", às objetivações mais complexas da cultura humana. Naturalmente, o acento caía sobre o ser social e seus produtos, assim como era característico de Hegel o fato de que o homem aparecesse como criador de si mesmo. (LUKÁCS, 1978, p. 2)
}

A ontologia marxiana, apesar de ter um enraizamento nas características da ontologia hegeliana, acaba distanciando todo elemento lógico-dedutivo e todo elemento teleológico no plano da processualidade histórica (LUKÁCS, 1978).

Atendo-se às colocações mais recentes, houve um combate às principais correntes teóricas do século XX intrinsecamente incompatíveis com o marxismo. Estas não apenas condenam o irracionalismo, como ainda as mais relevantes "verdades" burguesas que trazem a perpetuidade da ordem capitalista; traçam argumentos contra o estruturalismo que conduz à "morte do sujeito" e invalida os homens como construtores responsáveis por sua história; criticam o stalinismo, cuja concepção teleológica da história pontua a negativa da concepção marxiana; e lutam com os idealistas de todos os matizes que rejeitam a reprodução material como momento predominante da história e, a depender, o trabalho como categoria fundante do ser social (LESSA, 2012).

Lukács (1978), comentando o cenário crítico do atual estágio do debate dos problemas ontológicos, assinala que, nas últimas décadas, houve uma predominância do neopositivismo de modo a radicalizar velhas tendências gnosiológicas e recusar toda e 
qualquer postulação ontológica que não é vista como científica. Esse domínio se estendeu desde a vida filosófica até o mundo da práxis, dando pistas de como isso pode ser danoso.

\footnotetext{
Se analisássemos bem as constantes teóricas dos grupos dirigentes políticos, militares e econômicos de nosso tempo, descobriríamos que elas - consciente ou inconscientemente - são determinadas por métodos de pensamento neopositivistas. Deriva disso a onipotência quase ilimitada desses métodos; e, quando o confronto com a realidade tiver conduzido à crise aberta, essa situação produzirá grandes abalos a partir da vida político-econômica até a filosofia no sentido mais amplo do termo. (LUKÁCS, 1978, p. 1-2)
}

Daqui ele segue dizendo como as derradeiras tentativas ontológicas são extremamente problemáticas, notando ser suficiente para constatar isso os últimos desenvolvimentos de Satre, conhecido por iniciar a corrente do neopositivismo (LUKÁCS, 1978).

Dentre essas explicações supracitadas, há de se ler, em suas entrelinhas, que a ontologia concebida é a que identifica os homens com os indivíduos burgueses, pondo-os como essencialmente egoístas e proprietários privados, e que, por essa singularidade, não criariam relações outras para além daquelas que são alicerçadas na sociabilidade da propriedade privada e do capital, no seu fazer alienante e no modo como se vale do trabalho. A lógica de reprodução do capital toma para si aquilo que é mais caro ao ser humano: os meios de produção da sua existência envolvendo o domínio das práticas sociais e dos processos próprios da esfera produtiva que estabelecem a vida material.

O fato é que a ideologia burguesa consegue entender a centralidade ontológica do trabalho e, estrategicamente, toma para si sua consolidação: a mediação de primeira ordem, pressuposto da relação entre o ser orgânico e a natureza, e sua particularidade de condicionar todas as demais mediações. Na medida em que a organização social capitalista se constitui sobre a base de uma complexa estrutura sociometabólica de produção e reprodução da vida, na qual a mediação mais importante é feita pelo capital, tal processo passa a determinar as formas de objetivação do ser social.

Isso se desdobra no fato de se danificar o alcance de outro nível de interações que impulsionasse a humanidade a patamares superiores de sociabilidade, superando as relações mercantilizadas de viés capitalista. O que leva, consequentemente, à corrupção e alienação da essência antropológica do ser social e ao processo de inadequação ao gênero humano, colocando em xeque a real potencialidade das forças vitais da natureza humana. Tem-se a impossibilidade de se regular mediações indispensáveis para que possa haver a passagem de uma situação à outra e que novos processos sociais pudessem ser instaurados. Trata-se de uma processualidade histórica inerente às sociedades burguesas, caracterizada por modificações 
experimentadas pelo modo de produção, pelas relações sociais e pela própria subjetividade do ser social, o que gera graves influências às objetivações produzidas e, posteriormente, à generalidade humana.

Diante disso, Lessa (2012, p. 186-187) exibe o mote gerador de Lukács na sua trajetória da maturidade:

(...) explicitar as mediações sociais que fazem do homem o único demiurgo de seu próprio destino, de tal modo a demonstrar a possibilidade ontológica (que não significa a viabilidade prática imediata, nem implica num programa) da revolução comunista (na acepção marxiana do termo).

Para tanto, houve o esforço lukacsiano de desvelar e conhecer corretamente Marx. Nas circunstâncias momentâneas, a teoria de Lukács é a fundamentação mais bem feita, no âmbito da filosofia, da possibilidade ontológica de subversão revolucionária da sociedade burguesa.

\begin{abstract}
A consequência decisiva desse resgate é a recusa de toda a teorização que tenda a negar a possibilidade da emancipação humana do jugo do capital a partir de uma pretensa natureza humana, de uma pretensa essência humana, dada de uma vez para sempre, e que limite o desenvolvimento da sociabilidade aos padrões individualistas e mesquinhos tipicamente burgueses. (LESSA, 1996, p. 21)
\end{abstract}

Lessa (2012) pontua que Lukács vai ratificar, com sua Ontologia, que este projeto tentado por Marx realiza a sobrepujança de todas as concepções a-históricas da essência do homem, bem como das concepções teleológicas da história que fundamentalmente estão associadas a elas. Essa obra realça um novo modo de o homem olhar para sua história em que a sua essência seja uma implicação humana. Não há, então, determinantes que transcendam aos processos sociais e são explícitas as divergências sobre o estatuto ontológico das ontologias prévias a Marx, que consideram a autenticidade da essência em detrimento das manifestações fenomênicas.

Esta concepção permite a Marx postular que a essência humana é construto da História dos homens e que, no interior desta se distingue, enquanto categoria, por concentrar os elementos de continuidade do desenvolvimento humano-genérico e, jamais, por se constituir no limite intransponível da História humana. (LESSA, 2012, p. 198)

Costa (2009) complementa a citação acima afirmando que Marx, ao assegurar que o existente é passível de mutabilidade, critica de modo radical a suposta perpetuidade da ordem burguesa. Ao superar o capitalismo, existe a chance de se iniciar a produção da história. Isso tudo possibilita a ponderação e o tratamento de todas as categorias ontológicas. A obra de 
Marx se configura como uma nítida revolução teórica, instaurando uma ontologia de novo tipo e negando os rumores de uma especulação em termos de uma simples corrente ontológica.

\begin{abstract}
Tudo se integra na processualidade histórica, nada podendo ser anistórico. Categorias como, por exemplo: essência, fenômeno, singular, particular, universal, mediação e continuidade, são redimensionadas tendo como pressuposto que não são pensadas aprioristicamente em relação ao processo histórico que lhe dá efetividade, isto é, elas não têm sentido a não ser em suas existências concretas e nas suas possibilidades. (COSTA, 2009, p. 10)
\end{abstract}

Aponta-se para a eliminação de alienações operantes em determinado meio social questionando o real destino dos homens. É decisiva ainda a forma como os homens reproduzem ou combatem a alienação: se a partir da exploração do homem pelo homem, ou de uma ordem emancipada socialista e comunista, como indica Lukács.

Em seus estudos, Lukács consegue perceber e se apropriar daquilo que é a riqueza da teoria social de Marx e passa a ter um desempenho expressivo no horizonte teórico-filosófico de resgate dos caracteres ontológicos do ser humano na tarefa árdua de subtrair de sua literatura uma ontologia. É nessa direção que ele formula uma rede complexa de sínteses filosóficas desenvolvidas nas categorias centrais da ontologia lukacsiana.

Nessa mesma direção, as pesquisas lukacsianas também levantam a veracidade dos problemas ontológicos como aspecto central na obra marxiana. Lukács comprova que há uma natureza ontológica no pensamento de Marx, o que não é um consenso dentro da própria tradição marxista, haja visto que nela existem questionamentos de que Marx estruturou ou não uma ontologia do ser social (COSTA, 2009).

Costa (2009) deixa transparecer a inclinação à recusa e redução da impostação ontológica existente no cerne ontológico-emancipatório do projeto de Marx, tanto por causas distantes da tradição marxista quanto pelas dificuldades internas, levando à fragilidade teórica das conquistas marxianas. A princípio, ele traz quatro motivos que explicam a razão dessa questão ser um ponto de tensão.

Em primeiro lugar pelo caráter especulativo frequentemente ligado à tradição da reflexão ontológica. Primeiro, por exemplo, pensemos no caráter idealista das ontologias de Aristóteles, Tomás de Aquino e Hegel. Segundo, pela tendência gnosiológica, própria do neopositivismo e do irracionalismo pós-moderno, que hiperdimensiona o sujeito mesmo quando busca negá-lo. Terceiro, pelo sociocentrismo, que dissolve a natureza nas relações sociais, ou seja, os homens pensam e fazem da natureza que existe, não tendo esta, portanto, mais uma existência autônoma. Por último, pela perspectiva de colocar a práxis como o núcleo 
da problemática do marxismo dissociada de sua fundamentação concreta no metabolismo entre o homem e a natureza. (Ibidem, p. 1)

Nesse sentido ainda, Costa (2009) apresenta condutas antiontológicas de alguns estudiosos, que são fruto do processo de divulgação e de desenvolvimento posterior do que culminou na tradição marxista e trouxe um conjunto de desfigurações teóricas provocadas pela intromissão de elementos alheios à essência da obra marxiana. Althusser (2002 apud COSTA, 2009, p. 2) alega que “(...) qualquer impostação ontológica é vista como um obstáculo epistemológico oriundo da ideologia do humanismo teórico". Prado Júnior (1981 apud COSTA, 2009, p. 2) cita que “(...) o núcleo estruturante do pensamento de Marx também é a teoria do conhecimento". E segundo Benoit (2003 apud COSTA, 2009, p. 2), “(...) a tentativa de encontrar uma ontologia na obra de Marx é resultado de um transpassamento ilegítimo da lógica hegeliana à perspectiva marxiana, pois qualquer postura ontológica estaria associada à velha metafisica (...)”.

Lukács, em defesa da organização feita por Marx dos embasamentos de uma nova ontologia, realiza dois movimentos. Primeiro, ao explorar os textos marxianos, ele faz uma interpretação da impostação ontológica que a permeia através do que ele chama de "princípios ontológicos fundamentais de Marx”. Estes são enunciados diretos do ser social em suas afirmações ontológicas. E segundo, quando Lukács se volta para o tratamento sistemático das mediações ontológicas que fundam a historicidade da essência do homem. Investiga, principalmente, quatro complexos: trabalho, reprodução social, ideologia $e$ alienação, que são prerrogativas para a autonomia humana diante da processualidade social e imprescindível para a autogênese do ser social.

Esses dois movimentos irão garantir a radicalidade da crítica de natureza ontológica que há na revolução teórica marxiana. Por meio de encadeamentos concretos, Marx institui um novo perfil ontológico imanente na posição hierárquica fundante do mundo sobre a subjetividade e sobre temas gnósio-epistemológicos.

A perspectiva ontológica mostrada por Lukács é a retomada e o aprofundamento das reais especificidades e categorias determinantes do ser social que ele descobre e/ou estabelece. Elas estão abalizadas e dialogam com os traços ontológicos apurados por Marx. Isto é, a reafirmação do que incide nos processos históricos do ser social e da tese marxiana da prioridade ontológica do trabalho.

O pressuposto da ontologia lukacsiana é tirado diretamente em Marx e, por esta razão, parte da definição de que as condições de existência dos homens se dão por vias exclusivas do metabolismo com a natureza em que sua contínua transformação é 
teologicamente posta e está passível a nexos causais, ou seja, trata-se do ato de trabalho. Este é a atividade ininterrupta e inerente ao processo de produção da vida material humana como práxis social. "É, portanto, a partir desta relação dialética entre corpo orgânico e inorgânico que podemos compreender o estatuto ontológico proposto por Marx e desenvolvido por Lukács" (SILVA, 2014, p. 3). Dentre as categorias primordiais participantes do complexo do ser social estão a sociedade, a linguagem e o trabalho. É este o momento crucial no desenvolvimento dos homens na produção do novo que oferece os recursos necessários à criação de estágios mais complexos de formações sociais particularizando a vida em sociedade em relação à natureza (LESSA, 1996).

Como momento predominante em caráter de distinção das outras esferas ontológicas, o trabalho é lócus da criação do "novo" na intervenção sobre a natureza ante ao atendimento das necessidades mais imediatas de produção dos materiais imprescindíveis à reprodução social e daquelas necessidades estabelecidas na dinâmica do movimento histórico. "Ou seja, o ser social intervém na natureza através de construções mediativas que a transformam" (SILVA, 2014, p. 3). A cada objetivação, os atos dos homens são incorporados à história humana, refletindo, no processo de acumulação, o desenvolvimento social e um mundo dos homens cada vez mais complexo e mediado. E este desenvolvimento passa por dois pontos rigorosamente relacionados: o desenvolvimento das forças produtivas e o desenvolvimento das individualidades.

\footnotetext{
A rigor, sem o desenvolvimento das forças produtivas não poderíamos ter a passagem da sociabilidade aos modos de produção mais complexos e, concomitantemente, sem o desenvolvimento das "capacidades" dos indivíduos estes não poderiam operar as relações sociais cada vez mais complexas envolvidas na passagem da sociedade a modos de produção cada vez mais desenvolvidos. A reprodução social, portanto, desdobra, segundo Lukács, dois "polos" indissociáveis: a reprodução das individualidades e a reprodução da totalidade social. (LESSA, 2001, p. 96)
}

A predominância evocada pelo trabalho na estrutura ontológica do ser social incide na sua centralidade na esfera produtiva da vida social, sendo uma exigência vinda das condições de existência dos homens. Por isso, tornam-se determinantes as assimilações feitas do trabalho pelos diferentes modos de produção, vez que isso implica nas afirmações ontológicas materializadas pelo ser humano. 
Após pontuar minimamente alguns aspectos que envolvem a ontologia lukacsiana, é interessante que se traga um pouco do curso de Lukács $^{2}$ através das suas sucessivas aproximações com a literatura marxiana. A ênfase é dar um realce na evolução intelectual, sobretudo no caminho de apropriação feito pelo pensador húngaro da textualidade de Marx. No entanto, há também descrições da trajetória lukacsiana de produção teórica, dos interlocutores e as ideias com quem ele debate, dando um panorama de toda sua fertilidade.

O objetivo não é esgotar esse curso, mas apenas despontar pequenos detalhes de momentos históricos e contextos filosóficos e ideológicos particularmente politizados que foram determinantes na modificação direcional incisiva do seu pensamento, o que muitos chamam de "virada ontológica". E para a lapidação do conceito sintetizador original nos trabalhos da maturidade permeada de influências da doutrina marxista: a estética e a ontologia do ser social. Por essa ideia, leia-se: "Esta matriz, vocacionalmente sociocêntrica, é a questão da apropriação da dinâmica histórico-social pelo homem enquanto ator social concreto; o que significa, portanto, que se trata da questão da inserção de um sentido humano consciente no desenvolvimento social" (PAULO NETTO, 1981, p. 40; Grifos do autor).

Embora Paulo Netto (1981) faça a advertência sobre o perigo da periodização, ele traz uma abreviação esquemática bem coerente que dá pistas bastante importantes das contradições e do progresso lukacsiano como um todo. Incluem-se os trânsitos teóricoideológicos assegurando dados para a concretização de algumas superações com conservações postas por Lukács e, simultaneamente, sugerir seus efeitos, sem secundarizar a dialética envolvida:

A transição do período neokantiano ao pré-marxista assinala a passagem de um
estágio intelectual pré-dialético a outro, onde a concepção da realidade como um
conjunto dotado de movimento e fluidez conduz ao abandono da preocupação
metodológica formalista - típica da tradição kantiana, com ênfase na elaboração de
hierarquia e tipologias - e à historizaçao de conceitos e categorias; essa tradição,
contudo, não levou à efetiva ultrapassagem do fundo desespero (veio
kierkegaardiano) que animava o pensamento de Lukács. Comparada com ambos, a
primeira fase marxista de Lukács registra um enriquecimento temático
extraordinário, centrado na formulação de uma filosofia da história de caráter

\footnotetext{
${ }^{2}$ Em uma manobra análoga ao que se passou com Marx, Paulo Netto (1981) adverte sobre os cuidados de se periodizar o percurso científico de pensadores relevantes à base de fragmentações e rupturas como blocos autossuficientes, o que, em certa medida, não opera um desprezo ao seu passado, mas ocasiona uma contraposição errônea e vulgar, conduzindo a deformações no perfil ideológico-cultural. Neste caso, de Lukács, deixa-se de questionar nexos inseparáveis e dialéticos que enlaçam as várias fases da linha evolutiva do pensador. Segue dizendo que modificações, transições e até mutações garantem minimamente a autenticidade intelectual, podendo haver uma fidelidade às certas ideias principais que exigem uma análise reformulada e mais adequada do objeto de reflexão, sendo este a orientar as mediações a serem feitas. Coloca também a maneira mais coerente de se olhar para a evolução lukacsiana sob um duplo condicionamento: "a atenção à totalidade da obra de Lukács e a referência ao momento histórico de que emerge. Em suma: a verdade da obra lukacsiana só é passível de ser tomada estabelecendo-se seu tempo e seu modo". (Ibidem, p. 30; Grifos do autor)
} 
totalizador que, na fase seguinte, criticada e expurgada de laivos hegelianos e abstratos, é substituída por uma etapa de discussões metodológicas mais estreitas, com a perda (e isto não é casual, remetendo para a alteração da perspectiva política de Lukács) de categorias que só posteriormente seriam resgatadas (alienação, práxis, etc.). A terceira fase indica a decisão lukacsiana de integrar a contribuição leniana à sua reflexão, o que redunda na emergência de preocupações estético-culturais marginalizadas desde 1923/1924. A quarta fase, distinguindo-se da terceira por um conteúdo de crítica socialista mais evidente à era stalinista, prolonga-a no essencial. $\mathrm{Na}$ quinta e última, porém, novos parâmetros teóricos se apresentam: análise recai sobre complexos de problemas abandonados por quase quarenta anos (especialmente aqueles referidos à práxis) e o interesse pelo marxismo como sistema constituinte da inteligência histórica se organiza duplamente - com a crítica implacável do seu próprio desenvolvimento e com a reavaliação de momentos nucleares do passado cultural da humanidade. (Ibidem, p. 39)

Essas considerações de Paulo Netto (1981) passeiam por um cenário de cunho generalizante. É conveniente que os nortes dessa aproximação sejam também definidos pelo próprio Lukács, a partir do que ele define como etapas de seus encontros com Marx, nas quais expõem-se as características específicas indicativas das situações concretas de cada um deles.

Sobre a vida de Gyorgy Lukács, este nasceu em uma rica família judaica em 1885 e faleceu em 1971, na cidade de Budapeste, Hungria. Produziu numerosos ensaios e livros polêmicos dedicados a temas filosóficos, políticos e literários.

A sua vinda de uma família abonada financeiramente propiciou-lhe uma formação teórica sólida. Diferente de outros marxistas que o precederam, Lukács vem de uma via acadêmica importante diante da maneira como se deu a consolidação de suas teorias analíticas ao não estar em contato direto e intermitente com a militância. Autores como Marx, Lênin, Rosa Luxemburgo, Gramsci, entre outros, sobressaíram-se por sua atuação político-ideológica e pelo fato de suas análises do real serem construtos arquitetados no "olho do furacão" (SILVA, 2014).

É inviável, portanto, a apreensão do desenvolvimento das sínteses lukacsianas sem a devida observância da dialética existente entre aquilo que ele fez de sua prática política em que se tem uma relação de oposição reformista ou de adesão crítica, e suas elaborações teórico-filosóficas, mais complexas, que culminam num avanço desses campos que se estendeu à afinidade com Marx e com o comunismo muito dissimilar.

Segundo Lukács (2010), seu primeiro contato com Marx foi na última fase da escolarização, quando teve acesso ao Manifesto Comunista e, depois, na universidade, ao ler algumas obras de Marx e Engels (O 18 brumário de Luís Bonaparte e A origem da família, da propriedade privada e do Estado), além do estudo mais detalhado do primeiro volume de $O$ capital, em 1908, para "uma fundamentação sociológica" de uma obra que se ocupava do drama moderno. Ficou impressionado com alguns conceitos centrais do marxismo: a teoria da 
mais-valia, a concepção da história como história da luta de classes e a articulação da sociedade de classes. Todavia, sendo um intelectual burguês, percebia que a teoria neokantiana, na sua posição de classe, era mais bem aceita se limitando, então, às influências marxianas nas esferas da economia e da "sociologia". Os elementos derivados de Marx que ele conseguiu absorver desse período, embora estivessem implícitos, puderam ser percebidos em seus modelos para uma "sociologia da literatura" através d'A filosofia de Simmel e os escritos sobre o protestantismo, de Max Weber.

De acordo com Paulo Netto (1981), existem duas comoções intelectuais que foram preponderantes para os próximos encontros - a de 1914-1918 e a de 1929-1933, intimamente vinculadas a uma dúplice crise com histórico-universal - a crise geral do capitalismo, manifestada na I Guerra Mundial, e a crise inicial da revolução socialista, aberta com o seu fracasso no Ocidente.

A primeira marcou o seu trânsito de um neokantismo angustiado a um neohegelianismo desesperado e messiânico, propiciando-lhe o segundo encontro com o marxismo; a outra assinalou o início do seu conhecimento adequado do leninismo, inaugurando a terceira etapa do seu encontro com Marx. (Ibidem, p. 33)

O segundo caso foi em decorrência de sua crise filosófica determinada objetivamente pela manifestação mais intensa das contradições imperialistas e foi precipitada pela eclosão da I Guerra Mundial. Despontou-se com sua passagem do idealismo subjetivo ao idealismo objetivo (Teoria do Romance) em que Hegel adquiriu cada vez mais importância, em particular, com a Fenomenologia do Espírito.

A deflagração da Primeira Guerra Mundial, entretanto, colocou em xeque o elitismo deste posicionamento - a menos que os fatos históricos fossem solenemente ignorados, era insustentável a manutenção de uma postura filosófica para a qual a historicidade concreta era uma dimensão inessencial. Daí o desespero lukacsiano, tipificado na evocação de Fichte: tratava-se de uma era de perfeita culpabilidade. A realidade de um mundo em crise geral não oferecia à tradição kantiana mais que duas alternativas: ou a via de uma epistemologia formalista (na esteira de Cohen) ou o aprofundamento do veio irracionalista (na trilha de Dilthey) Lukács recusou-se a ambas: dedicou-se ao estudo de Hegel.

Mas o recuso a Hegel não solucionou, praticamente, aquele desespero. Primariamente porque, com relação a Hegel, Lukács mantinha uma série de preconceitos kieregaardianos; secundariamente, porque as formas de ação concretas que Lukács concebia estavam, em grande escala, deformadas pelas teorias de Sorel, nas quais ele tentava localizar um pathos de que carecia a social-democracia de Kautsky. De qualquer maneira, a leitura de Hegel propiciou-lhe adquirir uma visão dinâmica da realidade histórica; e, sobretudo, o contato com a dialética garantiu-lhe que a própria realidade resolveria seus conflitos.

E então que eclode a Revolução de Outubro. E, com ela, dá-se a repentina superação do desespero lukacsiano (...). (PAULO NETTO, 1981, p. 34-35) 
Nesse movimento, tornava-se mais compreensível, para Lukács, o caráter imperialista da guerra com aprofundamentos em Hegel, em sequência, e na aproximação com Feuerbach, privilegiando nele apenas o aspecto antropológico. Os escritos da juventude de Marx passaram a ser ponto de interesse através da perspectiva hegeliana. Ainda sem entender o significado do materialismo para as questões dialéticas, ele somente postulou uma prioridade hegeliana do conteúdo sobre a forma e, sobre bases hegelianas, tentou sistematizar Hegel e Marx numa "fílosofia da história" (LUKÁCS, 2010).

No calor das revoluções de 1917 e 1918, ele ingressa no Partido Comunista Húngaro e, desde então, permanece no movimento operário revolucionário. A dedicação aos escritos econômicos de Marx e, mais intensamente, sobre a história, a história econômica, a história do movimento operário, adveio por força maior de seus trabalhos práticos, debruçando-se numa contínua revisão dos fundamentos filosóficos. A luta em dominar a dialética marxista persistiu por um longo tempo. Seu apego a um subjetivismo ultraesquerdista o impediu de compreender o aspecto materialista num sentido filosófico mais abrangente. Por um lado, em História e Consciência de Classe, ele consegue resolver questões da dialética, mesmo que de maneira idealista, por outro, ele vai a Marx através de Hegel (LUKÁCS, 2010).

Esta revisão, apoiada em nova base teórico-ideológica (a releitura de Lênin,
especialmente os "textos filosóficos", e o conhecimento de materiais inéditos de
Marx, sobretudo os Manuscritos de 1844), desenrola-se entre 1929 e 1933 ,
aproximadamente - o breve período berlinês de Lukács e as primeiras horas do seu
exílio na URSS. Ela assinala a ultrapassagem lukacsiana das postulaçães éticas que
fundavam a sua petição moral do socialismo; o manuseio de categorias político-
econômicas permite-lhe uma recolocação do problema do sentido da evolução
histórica e a utilização de categorias epistemológicas lenianas possibilita-lhe um
equacionamento do processo gnosiológico. A partir daí, Lukács pode inserir a
contribuição leniana na ortodoxia marxista e tornar esta última a base legítima para a
fundaça de um conhecimento histórico-social de tipo novo. (PAULO NETTO,
1981, p. 37)

Sobre o terceiro momento com Marx, Lukács (2010, p. 14) elucida suas ascendências:

Somente a íntima adesão ao movimento operário, devido a uma prática de muitos anos, e a possibilidade que tive de estudar as obras de Lênin e pouco a pouco compreender seu significado fundamental, propiciaram o terceiro período de meu interesse por Marx. (...) O materialismo dialético, a doutrina de Marx, deve ser conquistada a cada dia, assimilada a cada hora, a partir da práxis. (Grifos do autor)

Lukács deixa evidente que apenas com um tempo considerável de trabalho prático e de esforço intelectivo para compreender Marx é que a dialética materialista se revolveu como 
algo palpável em termos concretos para ele em uma caminhada que só estava começando. O exame da unidade e da totalidade do materialismo constituía um instrumento analítico para conduzir a prática, para o domínio das manifestações fenomênicas e da sua legalidade. Diante disso, ele entende que "O progressivo aprofundamento - ainda que contraditório e não linear - das obras de Marx tornou-se a história do meu desenvolvimento intelectual e, portanto, tornou-se também a história de toda a minha vida, na medida em que ela possa ter algum significado para a sociedade" (LUKÁCS, 2010, p. 15; Grifos do autor).

É, pois, na "virada" dos anos 30, que, de acordo com Oldrini (2013), na cidade de Moscou, se forma o Lukács maduro. Assim, ele lança os princípios conceituais que fundamentam a sua obra:

Ela se funda naquelas geniais críticas de Marx (e Lenin) a Hegel, por intermédio das
quais, pela primeira vez, Lukács vê claramente as consequências que derivam dos
contorcionismos idealistas hegelianos. Polemizando com Hegel, colocando-o em pé
- nas pegadas de Feuerbach no sentido materialista, Marx recupera ontologicamente
(conceito de "ente objetivo") aquilo que Hegel havia dissolvido. Mas, ao mesmo
tempo, vai além de Feuerbach, uma vez que sublinha com clareza que a humanidade
do homem tem o seu verdadeiro ato de nascimento na história; que o homem, como
ente que desde o começo reage à sua realidade primeira, ineliminavelmente objetiva,
é um "ente objetivo ativo", produtor de objetivações, um ente que trabalha; que, em
suma, a objetividade forma a propriedade originária não somente de todos os seres e
de suas relações, mas também do resultado do seu trabalho, dos seus atos de
objetivação. (Ibidem, p. 13-14)

Depois, uma após a outra, vão sendo marcadas as categorias que compõem o sistema lukacsiano da maturidade. Assim Lukács caminha por meandros que avançam em direção a uma concreta ontologia diante da alteração radical de sua relação com o marxismo e a transformação de sua perspectiva filosófica. Na interiorização da teoria marxiana materialista da objetividade, da totalidade objetiva e dialética, ele se põe na busca da construção sistemática do edifício filosófico do marxismo num programa de tratamento universalista, de uma fundamentação e constituição como teoria filosófica unitária, compreendendo seus problemas de um ponto de vista ontológico (OLDRINI, 2013).

O fruto dessa caminhada culmina, então, na última fase em que ele genialmente consubstancia todo seu aprimoramento filosófico e político mediante a apropriação do referencial marxiano e da doutrina marxista.

Seus escritos dessa fase derradeira testemunham um esforço metodológico vigorosamente dialético, onde os problemas da historicidade concreta, da alienação, da práxis, da manipulação social, da continuidade, do humanismo, da democracia socialista, do trânsito ao comunismo e da salvaguarda dos valores culturais do passado são tratados na instância de uma antropologia que busca estatuir-se à base 
de uma ontologia materialista e dialética. Aqui, a determinação do sentido que pode ser instaurado pelo homem no processo sócio-histórico não se dilui na abstrata força de uma necessidade histórica transcendente aos atores sociais nem se articula sobre uma noção ética imperativa em si mesma: a possibilidade de introduzir na história uma teleologia humanizadora rompe o âmbito da antropolatria racionalista e, sem perder o seu conteúdo libertário, se fundamenta nas virtualidades alternativas contidas no bojo dos próprios processos sócio-históricos que se problematizam pela intervenção consciente de classes e grupos sociais. (PAULO NETTO, 1981, p. 44)

Conforme Lessa (2012, p. 187), desde os anos 30 até sua morte, este rico itinerário teve como resultado duas grandes obras que balizam o espaço mental do "último" Lukács, a Estética e a Ontologia:

Dentre os momentos mais importantes desta trajetória temos seus estudos estéticos, que lhe possibilitam investigar a fundo os fenômenos ideológicos e sua relação com o desenvolvimento da reprodução social; seu acerto de contas com Hegel, que passa pelo O Jovem Hegel e por um capítulo de sua Ontologia, no qual distingue o "verdadeiro" do "falso" na sua obra e, finalmente, sua investigação das conexões categoriais mais genéricas da reprodução social que o conduzirão, no início dos anos sessenta, à descoberta desta "bela palavra ontologia" e a elaboração do que viria a ser seu último grande texto, a Ontologia.

No que se alude à estética e à ontologia, existem dois caminhos pelos quais se debruçam os estudiosos lukacsianos ${ }^{3}$ gerando sínteses muito proveitosas e significativas a respeito das teorizações desse filósofo.

Oldrini (2013) abrevia que o primeiro gira em torno do forte interesse pela estética e pela crítica da literatura, explorando questões de fundo estético: suas bases fundamentais e seu aporte ontológico. Coloca-se a capacidade do marxismo de resolver internamente os problemas da imanência estética da obra de arte, a tese de uma estética marxista autônoma e unitária, que poderia ser resolvida graças a uma solução dialético-materialista. Portanto, na esfera da estética, a partir dos anos 1930, crucial é isto: que a nova teoria forneça os princípios que regerão a construção de uma estética marxista de caráter objetivista. A determinação da essência e do valor estético das obras de arte no reconhecimento do mundo exterior pelo reflexo artístico da realidade, como uma objetivação de caráter social, revela as verdadeiras forças motrizes do desenvolvimento social e a especificidade do estético como um momento da complexa imbricação do contexto amplo da realidade.

Entre os tantos e tão significativos temas da grande Estética, Lukács trabalha com assuntos como a unidade/distinção entre reflexo artístico e científico, o predomínio não fotográfico, mas dialético da porção da realidade refletida, a "questão da objetividade da

\footnotetext{
${ }^{3}$ Alguns estudiosos lukacsianos: Carlos Nelson Coutinho, Leandro Konder, Marco Aurélio Nogueira, Sérgio Lessa.
} 
forma" e a da "partidariedade da objetividade" (no sentido leniniano), que cada reflexo estético do real, necessariamente, exprime o caráter de imanência, compacticidade e "imediata conclusividade" da obra de arte (OLDRINI, 2013).

O outro, como foi dito anteriormente, são formulações para a compreensão da relação do homem, nas dimensões de sua individualidade e do ser genérico, com sua própria história. Daí decorre, destarte, a elaboração das obras Para a ontologia do ser social (conhecida como "grande" Ontologia), compreendida de uma parte denominada histórica e de outra em que há uma exposição teórico-sistemática das categorias trabalho, reprodução, ideologia e alienação, e os Prolegômenos à ontologia do ser social ("pequena” ontologia), nos quais trabalhou até sua morte.

É importante, pois, situar que a ontologia do ser social é uma resposta a uma necessidade identificada por Lukács, quando ele percebe que esta teoria deveria ser a "introdução" para uma teoria geral de uma "Ética", ou, mais especificamente, para uma ética marxista a partir dos anos 40. A projeção desta adveio após a publicação da Estética, em 1960, retomando, sobre bases materialistas e dialéticas, suas preocupações juvenis. Para subsidiar teórico-filosoficamente a "Ética" projetada, ele se coloca na difícil empreitada de extrair de Marx e elaborar, a partir de seus textos, uma ontologia que se põe como peça fundamental para se pensar o sujeito capaz de assumir um comportamento verdadeiramente ético.

Feitas essas primeiras considerações, na busca do entendimento em torno dos traços ontológicos dos indivíduos sociais, com o intuito de estabelecer as mediações pertinentes e necessárias para a formação na área de Educação Física, é que são utilizadas as teorias construídas por Marx e Lukács, focando os elementos envolvidos nas bases da ontologia do ser social lukacsiano. Os procedimentos metodológicos estruturados para realizar essa investigação científica são baseados na revisão de literatura das obras desses autores que lidam diretamente com essas teorias. É um movimento no qual os fundamentos ontológicos do ser social são determinados e apropriados e, na "viagem de retorno", são identificadas as correlações com o complexo da Educação Física.

O direcionamento dado ao objeto de estudo é o método materialismo históricodialético no qual a dialética é compreendida, então, como uma postura, um método e uma práxis. Frigotto (2004, p. 73) dá esse contorno, ao apresentar a dialética materialista histórica como “(...) uma postura, ou concepção de mundo; enquanto um método que permite uma apreensão radical (que vai à raiz) da realidade e, enquanto práxis, isto é, unidade de teoria e prática na busca da transformação e de novas sínteses no plano do conhecimento e no plano 
da realidade histórica. Tem-se, portanto, uma perspectiva na qual a dialética "Para ser histórica tem que dar conta da totalidade, do específico, do singular e do particular. Isso implica dizer que as categorias totalidade, contradição, mediação, alienação não são apriorísticas, mas construídas historicamente" (FRIGOTTO, 2004, p. 73).

Partindo do princípio de que o conhecimento é produzido pela realidade objetiva, procura-se a compreensão do objeto investigado em sua totalidade, na direção do seu processo histórico, sendo esta realidade processual, e apreender o movimento que se coloca entre sujeito-objeto e objeto-sujeito, bem como parte-todo e todo-parte (FRIGOTTO, 2004).

Sobre a construção textual desta dissertação, ela está estruturada, no capítulo I, em apontamentos introdutórios sobre a concepção marxista de homem - trazidos pelo próprio Marx (1974; 1988; 1999; 2002-2003) e por interpretações de suas obras (FROMM, 1975; LUKÁCS, 2013; SCHAFF, 1967). No decorrer de nossos estudos, notamos a importância de se recuperar como Marx pensa o homem, pois tal compreensão seria necessária a fim de superar o debate sobre corpo - que está no centro da discussão da Educação Física - que, de alguma forma, continua a favorecer uma visão dicotomizada de homem. Tal entendimento da compreensão marxiana de homem - também iluminou nossa concepção sobre o processo de formação humana. Para tanto, foram explorados os seguintes traços da elaboração de Marx: a base materialista; a concepção de história; o trabalho; e a alienação.

No capítulo II, o enfoque é o de apontar que Lukács tem o papel importante de resgatar os princípios ontológicos do homem colocados por Marx ao incorporá-los na teoria da ontologia do ser social (LUKÁCS, 1978; 2012). Ele nos traz as mais importantes determinações da ontologia marxiana. Tais determinações, entre outras coisas, conduzem-nos a perceber tanto a inexistência da autonomização do método de Marx, assim como notar que a crítica da economia política é, na verdade, uma Teoria Social da ordem burguesa, que acaba por nos trazer elementos fundamentais para se compreender o que os homens são nessa determinada sociedade e também os fundamentos daquilo que os homens são em geral.

Para a mediação com a educação e com a educação física, já que nos importa o debate sobre a formação humana, o capítulo III é uma tentativa de apropriação das consignações teóricas que intentaram articular a ontologia de base marxiana e a educação, consubstanciada na proposta da Pedagogia Histórico-Crítica (MARSIGLIA, 2011; SAVIANI, 2011; SAVIANI; DUARTE, 2012). O estudo das correlações entre os pressupostos ontológicos e a prática educativa, com satisfatória produção no âmbito da educação, em nossa concepção, lança luzes a fim de iluminar o debate na/da Educação Física. Embora apontamentos a fim de se pensar a formação humana sistematizada estejam presentes nos dois 
primeiros capítulos, é no III capítulo que iniciamos uma discussão acerca das possibilidades de mediação da Pedagogia Histórico-Crítica com a Educação Física.

E, finalmente, são feitas as considerações finais construindo sínteses a partir das discussões empreendidas no decorrer dos capítulos anteriores. É, pois, uma tentativa de estabelecer mediações com o processo formativo da Educação Física a fim de colaborar para o debate crítico sobre a respectiva temática. 


\title{
CAPÍTULO I - CONCEPÇÃO MARXISTA DE HOMEM
}

O olhar mais atento nas obras de Marx torna visível o fato de que sua concepção de homem subsidia os contornos da formação humana. Portanto, é através da compreensão dos fundamentos dessa concepção que se condiciona o entendimento mais legítimo para se refletir sobre a formação do ser social. Nesse sentido, a finalidade deste capítulo envolve muito mais abarcar esses fundamentos do que se ater a discutir, num viés mais pontual, a formação humana.

O que se sugere, portanto, é uma tentativa de apreender a riqueza das análises ${ }^{4}$ construídas por Marx ante sua contestação por um "mundo de homens com homens mais humanos", com a tomada de consciência "para si" dos indivíduos sociais: a consciência que se emancipa. Homens "verdadeiros" 5 " e conscientes que produzam suas próprias condições de existência a fim de eliminar a autoalienação do homem "real". A filosofia antropológica de Marx problematiza a alienação do homem contra a perda de si mesmo e sua transformação em "mercadoria" inerente à desumanização e à mercantilização induzidas pela ordem social do capital. Para a filosofia marxista, o problema central é a existência do indivíduo real, que é fruto do que ele faz, de como ele age e cuja "natureza" se explicita na história social.

\begin{abstract}
Marx vê o homem em sua plena realidade como membro de uma dada sociedade e de uma dada classe, auxiliado em seu desenvolvimento pela sociedade e, ao mesmo tempo, prisioneiro desta. A realização total da humanidade do homem e de sua emancipação das forças que o aprisionam está vinculada, segundo Marx, ao reconhecimento dessas forças e à mudança social baseada em tal reconhecimento. (FROMM, 1975, p. 7-8)
\end{abstract}

É um impulso ao desmascaramento da alienação em suas formas profanas frente a mecanismos cada vez mais atuantes e complexos de (re) produção da organização capitalista. Nessas situações, a alienação econômica tem uma determinação maior, porque se usurpa da vida efetiva pela mediação da propriedade ${ }^{6}$ privada, que institui a contradição entre trabalho e

\footnotetext{
${ }^{4}$ As pormenorizações das formulações marxistas são traduzidas em suas partes constituintes: concepção filosófica, economia política e socialismo científico. Estas partes são de cunho teórico e político. Há limitações na abrangência dessas formulações quando o olhar se restringe apenas às elaborações teóricas descoladas dos ensejos e experiências políticas de Marx.

${ }^{5}$ É importante trazer as questões levantas por Schaff (1967) na oposição dos conceitos de homem "verdadeiro" e homem "real". O homem "verdadeiro" ou "universal" é aquele tipo ideal que corresponde à imagem das possibilidades de evolução da espécie humana, que cumpre as condições prévias agregadas na natureza e na essência do homem e tem o potencial de realizar tudo aquilo que os seres humanos podem ser. Já o homem "real" ou "alienado" são os indivíduos concretos tal como eles existem no mundo da alienação. São, assim, homens deformados e mutilados pelo trabalho alienado e pelo capitalismo nos quais se realiza a essência capitalista do homem sob as condições da alienação burguesa: o ser social burguês.

${ }^{6}$ Por propriedade, Marx (1999, p. 46) entende que “(...) é o poder de dispor da força de trabalho de outros".
} 
capital se afirmando de modo mais enfático e degradante. "Esta propriedade privada material, imediatamente sensível, é a expressão material e sensível da vida humana alienada" (MARX, 1974, p. 8; Grifos do autor). E é, por isso, que deve ser superada para a reinvindicação da vida humana efetiva como propriedade do mundo objetivo. Mundo engendrado pelos homens na concretização de suas forças essenciais postas em suas subjetividades objetivadas como retorno ao seu modo de existência humana, isto é, social.

O superar, como movimento objetivo que retoma a si a alienação. É esta a concepção que se expressa no interior da alienação, da apropriação da essência objetiva mediante a superação da sua alienação, a concepção alienada na objetivação efetiva do homem, na apropriação efetiva de sua essência objetiva mediante a aniquilação da determinação alienada do mundo objetivo, mediante sua superação, no seu modo de existência alienado. (MARX, 1974, p. 44; Grifos do autor)

Marx (1974) destaca, pois, o sentido da superação que precisa ser realizada. O foco é a reparação da perca do homem de si mesmo em situações próprias da sua vida em estado de alienação. E o inimigo a ser vencido é o fazer alienante dos homens.

Ao enfrentar esse problema, Marx descobre os determinantes ontológicos do ser social, mostrando o que os homens são e suas potencialidades, bem como as reais possibilidades de um projeto emancipatório posto em efetivação pela operacionalidade histórica do homem. "A coincidência da modificação das circunstâncias com a atividade humana ou alteração de si próprio só pode ser apreendida e compreendida racionalmente com práxis revolucionária” (MARX, 1999, p. 12). E, apesar de Marx responsabilizar o proletariado pela articulação dessa práxis revolucionária, as circunstâncias atuais convocam o coletivo social em sua totalidade. Segundo Marx (1999), as forças produtivas existentes e a formação de uma massa revolucionária que se revolte são os fatores materiais de uma subversão total. Revolta esta contra as condições específicas da ordem social existente e o modo próprio de se produzir a vida vigente, a "atividade total" sobre a qual se fundamenta. Propõe-se, assim, um protesto e um convite de caráter subversivo para emancipação humana e social da obstaculização do desenvolvimento do gênero humano no devir histórico pautado no interior da sociabilidade burguesa.

A perspectiva orientadora é a de que a obra marxiana constitui uma teoria social crítica fundada no trato investigativo de Marx em torno de seu objeto de estudo: a sociedade civil burguesa. De acordo com Húngaro (2008), a partir de uma visão ontológica de teoria, a teoria social é "a reprodução ideal do movimento do real" da ordem burguesa e de suas determinações constitutivas intrínsecas ao modo de produção capitalista. Ela possui uma 
nítida raiz politizada: “a teoria é subsídio para a ação revolucionária” (HÚNGARO, 2008, p. 22). O objetivo não é apenas o de interpretar o mundo, mas de entender para transformá-lo. Busca-se a superação em termos de uma revolução total da formação social que tem na burguesia a classe dominante.

\begin{abstract}
Trata-se, como veremos, de um processo "inaugurado" em 1843 e que, numa trajetória "acidentada", estará consolidado em 1857/58. Em 1843, Marx se põe às voltas com o entendimento da relação entre Estado e Sociedade Civil, instigado pela sua leitura da Filosofia do Direito de Hegel e percebe que o desvendamento dessa questão exigiria a compreensão do que é a Sociedade Civil. De 1843 a 1857/58, Marx se enfrentará com esse objeto até "concluir" o processo de aquisição do "arsenal categorial" necessário à sua compreensão. De 1857/58 em diante, teremos a fase de maturidade intelectual de Marx na qual serão consignadas/expostas as suas mais geniais descobertas. Não é à toa que a década de 1860 é a fase mais produtiva de nosso autor. De meados da década de 1870 até o final de sua vida, sua produção decairá e na proximidade de sua morte (em 1883) será praticamente inexistente. (HÚNGARO, 2008, p. 23)
\end{abstract}

A teoria social marxiana decifra as incongruências entre o Estado e essa sociedade em particular. Essa teoria se torna mais fidedigna porque Marx se aproxima da lógica essencial da realidade e dos fenômenos sociais concretos, ao apresentar as determinações do "ser social burguês", visto que descobre sua gênese, anatomia e contradições. Existe nela uma filosofia do homem. É ainda uma impostação ontológica que se expressa e se generaliza na ontologia do ser social em conformidade com o que é afirmado pelas leituras de Lukács dos textos de Marx. É também colocado como central a determinação da especificidade do ser social, distinta das outras formas de ser. $O$ ser social é concebido como um complexo de complexos cujo momento ontológico articulador é a produção material da vida social, tem no trabalho seu elemento fundante e nas objetivações humanas o substrato para a composição da História (HÚNGARO, 2008; Grifos meus).

A inflexão acerca das dimensões ontológicas introduzidas por Marx permite a manifestação da forma concreta de ser humano. Sinaliza-se assim a processualidade pela qual o homem se realiza enquanto tal, cuja condição é um ser social visto como um processo permanente de objetivação. Homens que vivem num constante processo de construção e desconstrução de si mesmos e do seu mundo através de suas subjetivações objetivadas ${ }^{7}$ : os

\footnotetext{
${ }^{7}$ Há de se destacar que, no capitalismo, tanto a objetivação quanto a subjetivação estão fragmentadas, consequentemente também estarão deformadas a subjetivação objetivada e a objetivação subjetivada em condições de alienação. É possível afirmar que os efeitos danosos podem perpassar muito mais a subjetivação objetivada, uma vez que a subjetividade do indivíduo social é determinantemente degradada. Mesmo com a alienação, existe a possibilidade da explicitação de uma objetivação subjetivada ainda que esteja carregada de vestígios ideológicos burgueses.
} 
autênticos criadores da História. E é a partir disso que se delineia, entre outras questões, a filosofia antropológica marxiana.

Ainda nos dias de hoje, o estudo da obra de Marx não é obsoleto ou utópico. Continua a ser um pensador contemporâneo ao momento histórico presente e absolutamente necessário, apesar de insuficiente, embora consiga explicar a materialidade imprescindível à formação histórico-social burguesa. Os pretextos que justificam a atualidade das teorizações marxianas concordam com os mesmos que as validam. Nesse sentido, Húngaro (2008) faz duas observações. A primeira diz respeito à universalidade de suas obras por estarem limitadas pela permanência e reprodução da sociabilidade humana, na qual o capital regula o processo de trabalho. Nesse caso, as categorias de análise descobertas por Marx são referenciais, visto que, sem elas, fica impossibilitada a compreensão do modo de produção capitalista. A segunda observação evidencia que o esgotamento do potencial analítico das categorias marxianas só acontece mediante a deterioração das relações sociais de produção da ordem capitalista. O que não inviabiliza o fato de as obras de Marx contribuírem para o entendimento de outras formações sociais. Ou seja, para entender as particularidades acerca da/na sociedade burguesa, as laborações de Marx devem ser consideradas para as possíveis mediações e diálogos a serem feitos.

Sobre fundamentos do humanismo marxista, é relevante um olhar diferenciado, ou seja, um redescobrimento da “(...) imagem de Marx como investigador do problema do indivíduo humano, como lutador da felicidade" (SCHAFF, 1967, p. 2). O retorno a Marx gera possibilidades outras para se motivar a prática revolucionária. Para Schaff (1967), a alteração das condições objetivas do problema permite que o conteúdo da obra marxiana seja visto de forma distinta e que a interpretação de Marx se dê por outros vieses sob as novas e alteradas circunstâncias. A modificação do ambiente social e histórico pode acarretar novos elementos ao problema do indivíduo humano, que outrora não poderiam ser identificados até porque não existiam ou eram "insignificantes". E, mesmo assim, com sua transcendência histórica, o humanismo marxista pode oferecer recursos teóricos de modo a condicionar soluções plausíveis.

Para tanto, as discussões serão baseadas na observação dos componentes categóricos da antropologia filosófica presentes em dois trabalhos de Marx, a saber: Manuscritos Econômico-Filosóficos, especialmente o terceiro, e A Ideologia Alemã. Ainda são admitidas as influências de Eric Fromm - Concepção Marxista do Homem - e Adam Schaff - $O$ marxismo e o indivíduo. Essas influências são valiosas pela pertinência das considerações 
desses autores no propósito de pesquisar e sistematizar as questões centrais do humanismo marxista e na "simplificação" dos textos originais de Marx.

Antes, porém, é indispensável citar alguns condicionantes sócio-históricos referentes a esses trabalhos marxianos para que suas implicações e seus conteúdos possam ser melhor percebidos.

Os Manuscritos Econômico-Filosóficos (ou Manuscritos de 1844 e Manuscritos de Paris) vêm de uma fase demarcada pela atenção ao estudo da economia política e pelo contato com Engels. É um conjunto de três cadernos dividido em duas partes: uma crítica à economia política e uma investigação da Fenomenologia do Espírito, de Hegel ${ }^{8}$. Nota-se uma transição entre suas preocupações filosóficas e essa crítica (HÚNGARO, 2008).

Húngaro (2008) afirma que, em seu percurso intelectivo, em 1844, Marx chega a uma fase em que os ganhos o conduzem à missão de procurar o apanhado teórico para paramentar a "arma da crítica". Esta é a ferramenta que a classe menos abastada, como sujeito histórico do movimento revolucionário, se valerá para a luta contra os percalços de sua existência, a partir dos interesses antagônicos em relação à burguesia. Esse Marx se identifica com o comunismo. Trata de revolução e do fato da insuficiência de uma emancipação política: é preciso mais, é preciso que ela seja o passo inicial para a emancipação humana. Assim, ele toma ciência de que o grande ponto é a compreensão da sociedade civil burguesa. Daqui em diante, ele encara a economia política.

Os Manuscritos Econômico-Filosóficos (MEF) são dedicados aos conceitos de homem, alienação, emancipação, entre outros, e consubstanciam os conhecimentos prévios adquiridos por Marx da Economia Política (EP), a partir de três categorias: propriedade, dinheiro e trabalho. Marx coloca esta última como eixo central das discussões, havendo, porquanto, um contraponto e uma negação à concepção de trabalho com a qual a EP atuava.

Tendo em vista que na EP o trabalho é a essência da propriedade privada como produtor de valor numa ordem social na qual o ser genérico do homem aparece em oposição ao ser singular, Marx problematiza a generalidade burguesa como a própria negação do homem. Ele afirma que nessas circunstâncias se instala a hipertrofia da singularidade, acarretando o empobrecimento e a incompatibilidade ao gênero. O ser social burguês é, pois, egoísta e individualista. Embora a singularidade imediata não possa ser suprimida, pois constitui os seres humanos, ela pode ser transcendida pela adequação do homem ao desenvolvimento genérico (HÚNGARO, 2008).

\footnotetext{
${ }^{8}$ Marx (1974) aponta que, nessa parte, ele faz algumas indicações acerca da dialética hegeliana em geral, da exposição feita na Fenomenologia e na Lógica, e da relação do moderno movimento crítico com Hegel.
} 
Marx também debate acerca da contradição entre o indivíduo e o gênero na sociedade capitalista que, fundada na propriedade privada, faz a conversão dos homens à unilateralidade assentada na parcialidade burguesa e no trabalho ao status instrumental de subsistência, contraindo os contornos da alienação. Por efeito, a abordagem de Marx ao trabalho acontece no âmbito da objetivação humana (HÚNGARO, 2008).

A discussão feita tem o pressuposto de que a existência do homem precede da sua capacidade de se objetivar. Assim o trabalho, como forma elementar das objetivações humanas, é privilegiado por estabelecer a condição do mundo dos homens e de sua vida material na intervenção intencional sobre a natureza. É a mediação para a antropogênese do indivíduo social: o trabalho humano é a especificidade do ser social (HÚNGARO, 2008).

\footnotetext{
O que Marx aponta, sinteticamente, em 1844, é que o trabalho é a objetivação especificamente humana que funda o conjunto das objetivações humanas e, por isso, é a própria essência humana. Porém, essa essência não deve ser interpretada como uma essência fechada, atemporal, mas como um conjunto de atributos, de qualidades, de possibilidades que este ser vem desenvolvendo no curso de sua trajetória histórica. (Ibidem, p. 50)
}

Entre o que foi pontuado nos MEF, Marx ainda dá pistas do processo de humanização. Em suas sínteses, ele argumenta que tal processo parte do enriquecimento das singularidades efetivado pela adequação ao gênero humano. Isto é, ocorre pela apropriação das objetivações construídas historicamente pelos homens. Esse enriquecimento, por outro lado, pode ser impedido pelas nuances que envolvem a propriedade privada e as relações sociais pautadas em sua estruturação (HÚNGARO, 2008).

Outro ponto importante que Marx comenta é a relação entre cultura e natureza, sendo, pois, uma construção do gênero.

\footnotetext{
Nos Manuscritos de 44, Marx, ainda com um "pé na filosofia”, está reconstruindo, sob uma ótica crítica, as categorias da Economia Política e, principalmente, entre elas, o trabalho. Tendo este como práxis fundante de todas as objetivações humanas, Marx está desenvolvendo a ideia de um homem total, inteiramente realizável e, por isso, a crítica contundente à alienação. (HÚNGARO, 2008, p. 52)
}

Diante dessa visão de ser humano, pela interação com a EP, ao sublinhar o trabalho desenvolvendo uma gama de determinantes sobre o ser social, Marx elabora uma radical concepção antropológica. Esta o faz romper definitivamente os laços com Feuerbach, tendo em vista a atribuição naturalista e positivista do ser passivo e sofredor a qual ele sujeita o 
homem ${ }^{9}$. Ao mesmo tempo, Marx vê a necessidade de retroceder às influências hegelianas para se apropriar, por um viés materialista, do postulado dos homens que se autocriam na atividade produtiva consciente. Com a colaboração de Hegel, Marx se lança no empreendimento de um "acerto de contas" mais amplo que envolve toda a filosofia póshegeliana (HÚNGARO, 2008).

Esse movimento de afastamento e reaproximação se desdobra na segunda parte dos escritos que baliza uma autocrítica de Marx e Engels com suas formações anteriores em 1845/1846: A Ideologia Alemã. Esta obra está direcionada por dois horizontes: o enfrentamento da filosofia alemã contemporânea dessa época e, como dito acima, o balanço de suas formações, embora este último seja muito mais proeminente. Marx e Engels buscavam identificar as origens e as lacunas na ampliação de suas trajetórias (HÚNGARO, 2008).

A publicação de A sagrada família ou a Crítica da crítica crítica é a primeira investida ao "acerto de contas". "Essa obra constitui um balanço duríssimo, corrosivo, à intelectualidade alemã que não deu o passo progressista rumo à política, que circunscreveu sua ação ao domínio puramente especulativo" (HÚNGARO, 2008, p. 56). Entretanto, nessa ocasião, não acontece o embate a Feuerbach.

No conteúdo de A Ideologia Alemã, Marx e Engels especificam suas concepções de história, sociedade e economia no enfrentamento com Feuerbach, dando densidade teórica ao viés antropológico desenvolvido nos MEF e estendendo grande parte de seu acervo categorial (HÚNGARO, 2008).

Ainda segundo Húngaro (2008), a partir da noção de ideologia enquanto idealizações que ignoram seus condicionantes sócio-históricos, representando uma falsa de que se autolegitima e tem uma operacionalidade histórica, Feuerbach é enxergado como um ideólogo que, assim como outros pensadores, não reconhecem seus determinantes históricos. E é por essa razão que Marx e Engels rechaçam a “ideologia alemã”. Todavia, isso é compreensível no contexto que antecede 1848, pois, no período subsequente, a burguesia promove a depreciação dos ideais revolucionários e se coloca como classe conservadora, expressando sua “decadência ideológica” e contribuindo para o processo de mistificação da história.

Abreviando, conforme o que escreve Húngaro (2008), nos resultados teóricos desses autores, tem-se a brilhante explicitação da compreensão de história na qual os homens a concretizam ininterruptamente num desenvolvimento que incide na produção material da

\footnotetext{
${ }^{9}$ As relações de Marx com Hegel e Feuerbach serão melhor tratadas no decorrer deste capítulo, principalmente no que se refere à concepção materialista desenvolvida por Marx.
} 
vida. Dessa produção, emana a garantia do atendimento das necessidades imediatas e da reprodução da vida social. O que os homens são concorda, então, com os processos produtivos referentes ao que é e como é produzido. Nessa equação, o que pesa é o modo de se produzir, cujo marco das relações sociais são aquelas de propriedade que determinam as primeiras, tornando-as próprias de uma determinada sociedade e as submetendo às forças produtivas. Por conseguinte, há momentos em que as relações da estrutura produtiva ocasionam um entrave para a expansão dessas forças. Marx e Engels abordam historicamente como as diferentes formações sociais organizaram a produção, privilegiando a divisão social do trabalho e os modelos de propriedade.

Nas análises de Húngaro (2008), partindo do suposto da história dos seres humanos produtores de sua vida material, Marx e Engels tratam do complexo consciência e atividade material por uma relação de determinação. Reconhece-se que o dado primário é a produção material dando os limites da ontologia do ser social. A totalidade dos homens reais e vivos e suas condições materiais de existência precedem o pensar, o idealizar, a consciência humana. Entretanto, embora haja uma determinação, a consciência não é um reflexo da vida material, não havendo, portanto, uma identidade entre sujeito e objeto.

A Ideologia Alemã é, assim, a consignação da passagem de uma crítica filosófica à composição de uma teoria social, decorrendo daí teses fundamentais sobre a prática e o projeto de procedência revolucionária (HÚNGARO, 2008).

Nesses dois trabalhos, inaugura-se a ontologia do ser social e se encontram as raízes profundas da análise antropológica e do humanismo que vão ser tracejados por Marx ao longo de suas produções (HÚNGARO, 2008).

Apesar das demandas relativas ao problema do indivíduo concreto e de sua relação com a sociedade serem a preocupação de Marx em seus estudos embrionários, ele não abandona tais demandas posteriormente, visto que a visão sobre este indivíduo e sua felicidade é a espinha dorsal de suas teorizações e a chave para a percepção dos domínios constituintes de seu pensamento. Consequentemente, a imagem de "dois Marx", na qual há um hiato e/ou uma oposição entre o "jovem Marx" e o "Marx amadurecido", é uma falácia. Segundo Schaff (1967, p. 26), é preciso exceder esse argumento “(...) e isto porque, sem dúvida, conservou-se a continuidade na evolução de semelhantes concepções, e porque - o que é mais importante - conservou-se a continuidade da tese fundamental do sistema, ainda que se tenha modificado o feitio de sua formulação e conclusão". Nem o jovem e nem o Marx maduro deixaram de ter no indivíduo humano real o seu ponto de partida. 
Schaff (1967) diz que as defesas em torno do isolamento do "jovem Marx" e seu confronto com o maduro deveriam suscitar um estado reacionário. Isso foi “(...) sob a alegação de que a obra de Marx representava uma unidade orgânica, impossível de subdividirse em elementos isolados, e até opostos, no plano ideológico, sem ferir os postulados fundamentais da História (acrescentaria: também os postulados do senso comum)" (SCHAFF, 1967, p. 23).

O ataque à problemática da falta de unificação no processo evolutivo do pensamento de Marx deve ser explicado pelo método histórico. O conhecimento da história das ideias marxistas, conforme seu movimento, evolução e dinamismo, sintetiza a importância dos escritos do jovem Marx para a correta compreensão de suas tendências derradeiras (Ibidem).

Temos, aqui, um pensador. Há mais de quarenta anos ativo no campo da criação
espiritual. Em tal período, sofreu uma evolução, que o levou, da filosofia do
idealismo, ao materialismo, e da política do democratismo e liberalismo burguês, ao
comunismo. Podemos distinguir fases de sua evolução e da formação de suas
concepções, vendo, simultaneamente, a ligação de tais fases, a maneira como cada
fase condiciona a seguinte. Apresenta-se o problema de qual viria ser a relação entre
o primeiro período da evolução e o período das ideias maduras. (SCHAFF, 1967, p.
26-27)

A dimensão histórica em sua compreensão correta e o pressuposto do método de Marx, que alega que aquilo que é mais complexo explica o que é mais simples, realçando assim o aspecto dialético das produções de Marx para efeito de coesão e coerência de sua obra científica. O problema da libertação do homem é seu objetivo central e a explicação do pensamento do Marx maduro precisa ser feita pelas premissas e teses da sua antropologia filosófica da juventude (SCHAFF, 1967).

A crítica das ideias da maturidade é dependente do teor tratado na juventude e o sentido da filosofia do homem do jovem Marx se torna compreensível, pois revela sua riqueza e alcança maturação na medida em que a primeira fase está necessariamente ligada às subsequentes. Surgem, na sua teoria social, os problemas cuja solução dedicar-se-á toda sua inspiração posterior (SCHAFF, 1967).

A desmistificação dessa falácia e o entendimento da estrutura da trajetória intelectual de Marx e de sua teoria social exigem, minimamente, algumas indicações ${ }^{10}$ acerca da sua concepção metodológica. Húngaro (2008, p. 22) traz então aspectos importantes:

(...) em primeiro lugar, que o dado primário é o objeto (a realidade) ao qual o investigador deverá estabelecer a máxima fidelidade; e, em segundo lugar, que o

\footnotetext{
${ }^{10}$ As determinações mais gerais do método de Marx serão trabalhadas no capítulo II de modo mais detalhado.
} 
sujeito investigador deve ser rico de mediações, ou seja, um sujeito rico intelectivamente, pois só dessa maneira poderá ser capaz de fazer a apreensão das determinações constitutivas de seu objeto de investigação.

Em termos práticos, esses dois aspectos sugerem como Marx, por uma razão que é totalizadora, toma o fato de que a realidade é o objeto material elementar, rompendo com sua aparente abstratividade ao torná-la mais determinada. Ele descobre aquilo que é específico do ser social. Depois, a ideia de "um sujeito rico intelectivamente" decorre da apropriação necessária feita pelo pesquisador do suporte teórico, com destaque para o conhecimento de fontes documentais e o exame da realidade, no atendimento da carência de mediações e determinações do objeto.

Há de se considerar que, durante esses 40 anos de trajetória intelectual, muitas foram as modificações sociais e históricas que influenciaram os contextos materiais de análise, investigação e exposição da realidade.

\begin{abstract}
Sintetizando este tópico da suposta diferença entre o jovem Marx e o Marx amadurecido: é verdade que Marx (como Engels), no decurso da vida, alterou algumas de suas ideias e concepções. Tornou-se mais adverso ao emprego de termos demasiado próximos do idealismo hegeliano; sua linguagem ficou menos entusiástica e escatológica; provavelmente, também, ficou mais desencorajado nos últimos anos da vida do que o estava em 1844. Todavia, a despeito de certas mudanças nos conceitos, no estado de ânimo, na linguagem, o cerne da filosofia exposta pelo jovem Marx jamais se modificou, e é impossível compreender seu conceito de socialismo e sua crítica do capitalismo, como formulada ulteriormente, salvo se se tomar como base o conceito de homem por ele apresentado em seus primeiros estudos. (FROMM, 1975, p. 79)
\end{abstract}

Sendo assim, é evidente que suas diferentes produções são díspares, tanto pelo conteúdo como pelo estilo intelectual (SCHAFF, 1967). É uma trajetória instável em meio a rupturas, continuidades, adesões e rompimentos (HÚNGARO, 2008).

Outra distorção relacionada ao humanismo de Marx é o fato de ser colocada em xeque a instigação imediata pelos temas filosóficos. A posição é a de que Marx tenha se distanciado e abandonado as problemáticas antropológicas. Esse afastamento se justifica pela necessidade de ir para outros campos do conhecimento (economia política, sociologia e política), visto que a filosofia oferecia limitações para o descobrimento das determinações do objeto de estudo (SCHAFF, 1967). Destaca-se, sobretudo, o peso das reflexões advindas da economia política ${ }^{11}$ como uma forma rudimentar de teoria social e da representatividade

\footnotetext{
${ }^{11}$ Húngaro (2008) aponta que os economistas políticos, dentre eles, Smith e Ricardo, que ganharam ênfase no estudo de Marx e buscavam investigar a anatomia e o funcionamento da sociedade burguesa. E, como resultado de seus intentos, descobriram que o trabalho é fonte de riqueza e várias categorias estruturantes do funcionamento dessa sociedade: capital, lucro, trabalho, juro, classes, mercado, propriedade privada, entre
} 
assumida por Marx na perspectiva da Crítica da Economia Política, porque ela fornece as categorias operantes na sociedade burguesa (HÚNGARO, 2008). O próprio objeto conduz o pesquisador a definir outros guias teórico-metodológicos no processo de ir além da aparência e da manifestação fenomênica desse objeto no estabelecimento das mediações pertinentes.

Essa mudança nos rumos de suas pesquisas é factível, em especial n'A Ideologia Alemã, panorama no qual Marx e Engels percebem que o conhecimento da sociedade civil e do Estado deve ser procurado, especialmente na crítica da EP ao invés da filosofia, que, mesmo sendo expressiva para que isso ocorra, não pode estar atrelada à "ideologia alemã" (HÚNGARO, 2008).

Além do mais, de acordo com Lukács (2012), não era da pretensão de Marx designar um método filosófico próprio ou um sistema filosófico. Ao longo do processo da fundação de uma concepção materialista que embasa sua visão filosófica, Marx se pôs em combate ao idealismo hegeliano e aquele de caráter mais subjetivista dos discípulos radicais de Hegel. A frustração no episódio da revolução de 1848 fez que com que seus interesses se voltassem para o estabelecimento de uma ciência da economia, induzindo muitos admiradores de seus escritos iniciais a acreditar que ele estivesse se tornando "apenas" um economicista e se afastando de discussões filosóficas, o que é incabível diante da análise de suas produções.

Essa conclusão se funda sobre características puramente exteriores, sobre a
metodologia imperante na segunda metade do século XIX, que estabelecia uma
oposição mecanicamente rígida entre filosofia e ciências singulares positivas,
degradando, com isso, a própria filosofia à condição de ciência particular por estar
fundada exclusivamente sobre a lógica e a teoria do conhecimento. A partir de tais
pontos de vista, a economia do Marx maduro pareceu à ciência burguesa e aos
modos de consideração por ela influenciados, inclusive entre adeptos do marxismo,
uma ciência particular, em contraste com as tendências filosóficas do seu período
juvenil. Mais tarde houve quem, sob a influência do subjetivismo existencialista,
construísse um contraste entre os dois períodos da produção marxiana. (LUKÁCS,
2012, p. 290)

O que se pode observar é que na verdade “(...) Marx não se tornou 'menos filosófico', mas, ao contrário, aprofundou notavelmente, em todos os campos, suas visões filosóficas" (Ibidem, p. 290). Em suas formulações posteriores, ele consegue aliar o desenvolvimento teórico de fenômenos econômicos e se ocupa em teorizar filosoficamente sobre temas emergentes do esclarecimento da totalidade desses fenômenos. Prova disso é que a linha metodológica de pesquisa marxiana leva para uma concepção de economia que rompe com os

outras. O trabalho é idealizado como a essência subjetiva da riqueza no interior da propriedade privada, o que implicou, necessariamente, no passo seguinte de reconhecer a essência geral da riqueza e o trabalho em sua forma mais absoluta, o trabalho em geral (MARX, 1974). 
padrões absolutizados de ciência da época, tratando os fenômenos econômicos isoladamente. Então, é pouco provável que Marx tenha sido um especialista em economia no sentido semântico restrito do termo.

\subsection{Traços fundamentais da concepção marxista do homem}

Os traços fundamentais da concepção marxista do indivíduo humano são manifestos, então, minimamente, em três aspectos diluídos no seguinte trecho, de Schaff (1967, p. 106107):

\footnotetext{
O problema do status ontológico do indivíduo está solucionado, com clareza, dentro da concepção marxista: o indivíduo humano é uma parte da natureza e da sociedade, o que determina o seu status ontológico. Trata-se daquela parte da natureza que transforma o mundo de maneira consciente e, como tal, é parte da sociedade. Como unidade natural-social, não exige fatores complementares além da realidade objetiva para sua compreensão. A solução do problema do status ontológico do indivíduo permite-nos, então, construir uma antropologia filosófica apoiando-se em toda a mundividência marxista, antropocêntrica e, portanto, autônoma, no sentido especial da palavra. (Grifos do autor)
}

De início, é preciso partir do indivíduo concreto como um complexo de complexos em que a análise da ambiência das relações sociais permite uma reconstrução do movimento do real bem mais verossímil. Revelam-se aspectos precisos dessas relações que se ocultam sob os fenômenos que se mostram à percepção aparente. Não se pode apartar a sociedade dos seus membros, pois “(...) não há sociedade sem que estejam em interação os seus membros singulares, assim como não há seres sociais singulares (homens e mulheres) isolados, fora do sistema de relações que é a sociedade" (PAULO NETTO; BRAZ, 2007, p. 37; Grifos do autor). A sociedade é a expressão dos modos de existir do ser social. É em sociedade que os homens constituem o seu caráter social e dele se constitui. Não há existência do ser social que não seja em um meio de sociabilidade.

Depois, a linha tênue entre ser singular e ser genérico: “(...) nenhum homem, tomado singularmente, expressa o conjunto de possibilidades do ser social. (...) o ser social é o conjunto de atributos e das possibilidades da sociedade, e esta é a totalidade das relações nas quais os homens estão em interação" (PAULO NETTO; BRAZ, 2007, p. 45). Soma-se a isso a passagem de que "Quanto mais os homens, em sua singularidade, incorporam as objetivações do ser social, mais se humanizam, mais desenvolvem em si o peso da sociabilidade em detrimento das 'barreiras naturais"' (PAULO NETTO; BRAZ, 2007, p. 46). De tal modo, um ser que existe como um exemplar da espécie e como indivíduo, um produto 
do desenvolvimento histórico e, tão logo, um produto social. O processo de humanização decorre da adequação do indivíduo às riquezas das objetivações produzidas historicamente, ou seja, a cultura humana como forma afirmativa da generalidade do ser social.

Marx (1974) alega que a propriedade posta na sociabilidade é a marca mais geral do movimento de existência do ser genérico determinado "em-si" e "para-si". Tanto o objeto como o sujeito são resultados da exteriorização e da materialização imediatamente na sociedade efetiva com outros homens. Um movimento de produção de reciprocidade: a sociedade produz os homens e estes a produzem e reproduzem-na.

\begin{abstract}
A essência humana da natureza não existe senão para o homem social, pois apenas assim existe para ele como vínculo com o homem, como modo de existência sua para o outro e modo de existência do outro para ele, como elemento vital da efetividade humana; só assim existe como fundamento de seu próprio modo de existência humano. Só então se converte para ele seu modo de existência natural em seu modo de existência humano, e a natureza torna-se para ele o homem. A sociedade é, pois, a plena unidade essencial do homem com a natureza, a verdadeira ressurreição da natureza, o naturalismo acabado do homem e o humanismo acabado da natureza. (MARX, 1974, p. 9; Grifos do autor)
\end{abstract}

A condição do indivíduo como ser social rompe com qualquer possibilidade de tensão entre o indivíduo e a sociedade. A singularidade e a individualidade do homem se exteriorizam e se confirmam na e para a vida social, compondo a totalidade da realidade. As obras humanas resultantes das singularidades formam a generalidade do ser humano.

\begin{abstract}
A vida individual e a vida genérica do homem não são distintas, por mais que, necessariamente, o modo de existência da vida individual seja um modo mais particular ou mais geral da vida genérica, ou quanto mais a vida genérica seja uma vida individual mais particular ou geral. (...) O homem - por mais que seja um indivíduo particular, e justamente é sua particularidade que faz dele um indivíduo e um ser social individual efetivo - é, na mesma medida, a totalidade, a totalidade ideal, o modo de existência subjetivo da sociedade pensada e sentida para si, do mesmo modo que também na efetividade ele existe tanto como intuição e gozo efetivo do modo de existência social, quanto como uma totalidade de exteriorização de vida humana. (MARX, 1974, p. 10; Grifos do autor)
\end{abstract}

Assim, o indivíduo, partícipe da natureza e influenciável pelas funções das circunstâncias de sociabilidade, é dependente da ação simultânea entre indivíduos e a totalidade social, surgindo, então, como uma obra dela, que está acondicionada pela forma de produção.

E o último, reserva a criação e o desenvolvimento do ser social: a autocriação concretizada no trabalho humano útil. Sua intervenção propriamente dita indiscutivelmente implica a materialização de modificações nos planos objetivo e subjetivo. O processo de 
trabalho é pensado, então, como a ação consciente do homem na realidade independentemente de qualquer modelo societário e elemento fundante do marco ontológico articulador que é a produção material da vida social.

O apontamento desses traços é uma tentativa, pois, de sobrepujar teorias abstratas e indeterminadas e de alcançar um esclarecimento efetivo do que são a sociedade e os homens, sua relação com a natureza e a especificidade de ser social. Trata-se, portanto, daquilo que é característico do ser social, o sujeito do trabalho: o indivíduo ativo e produtivo.

A compreensão destes aspectos perpassa e pode ser sistematizada por quatros elementos, a saber:

1) a base materialista: as origens ontológicas e as condições objetivas reais de existência. O "ser" tem prioridade ontológica. A consciência é entendida como um produto tardio do desenvolvimento do ser material, o que não implica dizer que o produto tardio tenha necessariamente um menor valor ontológico. A consciência tem sim um papel real no plano do ser e, por isso, não é carente de força material (LUKÁCS, 1978);

2) a acepção de história: consubstanciação dos atos humanos, suas objetivações, um produto social quando da coincidência de que o desenvolvimento histórico é o desenvolvimento do ser social. Isto em função do permanente movimento de vir-a-ser do homem ao produzir e reproduzir as condições objetivas de sua vida. O ser social é criador da História;

3) o trabalho: a maneira como o homem transforma e regula a natureza. Pressupõe-se o trabalho numa forma que exclusivamente pertence ao ser social;

4) a alienação: a expropriação do homem de si e a incompatibilidade ao gênero humano, especialmente em uma sociedade pautada na divisão social do trabalho e na propriedade privada dos meios de produção. Tem-se a exploração do homem pelo homem em que o trabalhador se apresenta no mercado como vendedor de sua própria força de trabalho. O trabalho é transformado em uma atividade empregada a favor da troca e da propriedade privada sinalizando o estranhamento como manifestação específica de exteriorização humana (MARX, 2002-2003). O foco é a análise da alienação material que traz sua intensificação na alienação econômica. 


\subsubsection{A base materialista: as origens ontológicas e as condições reais de existência}

As proposições de Marx são movidas pelo ser humano-sensível em seu processo de vida. Este é o pano de fundo para toda e qualquer tentativa de interpretação da teoria marxista de homem. Sustenta-se o olhar para os homens concretos e reais, expurgando falsas representações sobre si mesmos, o que são ou deveriam ser através da libertação das quimeras, das ideias, dos conceitos, dos dogmas, dos seres imaginários, do domínio dos produtos da consciência tornados autônomos que são correspondentes à essência humana carente de toda base real. De acordo com Marx (1999), os pressupostos dos quais ele parte são reais, podendo ser abstraídos apenas na imaginação. Trata-se dos indivíduos reais, da sua ação e das suas condições materiais de existência, tanto aquelas já pré-existentes quanto as que são produzidas por sua própria ação.

Portanto, como Marx se apoia numa base materialista, o materialismo histórico criado por ele deve ser ponderado em duas medidas que dialogam entre si: 1) no que se refere ao embate teórico com o idealismo, que considera que o mundo está dominado por ideias e conceitos entendidos como princípios determinantes; e 2) na idealização de sua base materialista de análise em que pesam as influências feuerbachianas postas também nesse embate.

Apesar de divergências em muitos aspectos do materialismo ${ }^{12}$, Marx se junta a Feuerbach no ataque ao idealismo, em especial o de Hegel, predominante na filosofia alemã. Segundo Marx (1999, p. 18-19):

\footnotetext{
Hegel completou o idealismo positivo. Para ele, não apenas todo o mundo material tinha se transformado num mundo dos pensamentos e toda a história numa história dos pensamentos. Ele não se limita a registrar as coisas do pensamento, mas procura também expor o ato de produção. (...) No sistema de Hegel, as ideias, os pensamentos e os conceitos produzem, determinam, dominam a vida real dos homens, seu mundo material, suas relações reais. (Nota de rodapé)
}

Marx inverte a determinação geral proposta por Hegel, na qual parte "dos homens ativos, reais e apresenta-se, tendo por base o seu processo vital real, o desenvolvimento dos reflexos ideológicos e ecos deste processo vital" (SCHAFF, 1967, p. 55). A consciência é

\footnotetext{
${ }^{12}$ Fromm (1975, p. 19) esclarece as distinções conceituais do materialismo e do idealismo no campo da filosofia enquanto correntes contrapostas: "Na terminologia filosófica, 'materialismo' (ou 'naturalismo') refere-se a uma opinião filosófica segundo a qual a matéria em movimento é o elemento constitutivo fundamental do universo. Por idealismo, pelo contrário, entende-se uma filosofia onde não é o mundo dos sentidos em permanente mutação que constitui a realidade, e sim essências incorpóreas, ou ideias".
} 
determinada pela vida, ou seja, considera-se, a priori, os próprios indivíduos reais e a consciência apenas na sua consciência. Ele acena às condições fundamentais da vida humana e como elas atuam definitivamente na constituição do ser humano. O que e como os homens são e suas produções espirituais são resultados da ação do homem sobre a "terra" no seu processo de vida. Segundo Fromm (1975), esse aspecto de "materialismo", o "método materialista" de Marx, é que se contrasta à visão de Hegel. É a exigência do estudo da verdadeira vida socioeconômica do ser social e da implicação do estilo real da vida do homem em sua mentalidade e sentimentalidade. "Quer isso dizer: não partimos daquilo que os homens imaginam, concebem, nem de como são os homens descritos, imaginados, a fim de chegar aos homens de carne e osso" (FROMM, 1975, p. 20). Marx renuncia à premissa de Hegel de que o homem está subjugado às forças extraterrenas, que transcendem a existência humana e alcançam o "céu". Essa premissa submete o indivíduo ao determinismo de suas ideias, conceitos e consciência.

No extremo desse entendimento, o pensamento marxista alega que a composição psíquica, a consciência, forma-se como resultado e expressão de determinadas condições sociais e dos processos de produção da vida material. As percepções, os valores, as ideias são, assim, como produtos históricos formados pela conexão da estrutura social e política com a produção em suas interferências de reciprocidade.

Os homens, no entanto, já nascem com certas possibilidades de evolução,
relacionadas à sua estrutura psicofísica, historicamente formada. Temos, então, o
resultado da filogênese, também historicamente condicionada. Mas o homem é um
produto da ontogênese, um produto social quanto às suas concepções, opiniões,
juízos de valor - num determinado grau de evolução biológica, lentamente
modificada. Aquilo em que o homem se transforma, na ontogênese, está
condicionado pela sociedade, de forma que permanece além de qualquer controle do
indivíduo. (SCHAFF, 1967, p. 72)

Tem-se a delimitação da especificidade da consciência e das produções espirituais e mentais do homem sem qualquer mistificação ou especulação. A produção de ideias, de representações, da consciência está diretamente ligada à atividade material e às trocas materiais dos homens. "O representar, o pensar, o intercâmbio espiritual dos homens, aparecem aqui como emanação direta de seu comportamento material” (MARX, 1999, p. 36). A política, as leis, a moral, a religião, o sistema de valores e a cultura de um povo são combinados com atividade e a conduta material, e as relações inter-humanas.

Marx destaca quão é necessária uma discussão de dimensão ontológica mostrando o lugar de onde a consciência deve ser apreciada, pois "Não é a consciência que determina a 
vida, mas a vida que determina a consciência" (MARX, 1999, p. 37). Sendo assim, seu posicionamento não era contra as ideias propriamente ditas, pelo contrário, ele "atacava" as ideias que não eram na realidade humana e social longe de ser um lócus ontológico do real (FROMM, 1975). Ele contesta, por assim dizer, as ideologias, o falseamento da realidade tal como ela é em sua materialidade, o que contribui para a alienação dos homens.

\footnotetext{
A consciência jamais pode ser outra coisa do que o ser consciente, e o ser dos homens é o seu processo de vida real. E se, em toda ideologia, os homens e suas relações aparecem invertidos como numa câmara escura, tal fenômeno decorre de seu processo histórico de vida, do mesmo modo por que a inversão dos objetos na retina decorre de seu processo de vida diretamente físico. (MARX, 1999, p. 37)
}

Para Marx, o sistema hegeliano poderia e deveria ser confrontado através do problema do indivíduo. Em Hegel, o sujeito real aparece como efeito, como um dado secundário, quando ele parte dos predicados da determinação geral ao invés do ser concreto. Isso porque o dado primário se põe como uma especulação metafísica. Na visão marxista, os predicados do sujeito estão em função da totalidade das relações sociais datando de onde eles são assentados: a consciência, a linguagem, a personalidade, a natureza corporal são, assim, produtos sociais.

Acerca de Feuerbach, tem-se que, em seu materialismo, ele parte do homem vivo, do indivíduo de carne e osso que é componente da natureza. Um dos seus feitos foi o de "(...) ter fundado o verdadeiro materialismo e a ciência real, ao fazer igualmente da relação social 'de homem a homem' o princípio fundamental da teoria” (MARX, 1974, p. 34; Grifos do autor). Sob o ponto de vista histórico e filosófico, surge uma nova perspectiva que abalou a filosofia alemã em torno do hegelianismo. "Feuerbach é o único que tem a respeito da dialética hegeliana uma atitude séria, crítica, e o único que fez verdadeiros descobrimentos nesse terreno. Ele é, em suma, aquele que verdadeiramente superou a velha filosofia" (MARX, 1974, p. 33; Grifos do autor). Assim, Feuerbach foi preponderante na evolução do materialismo em virtude da virada radical no paradigma da concepção antropológica teocêntrica e heterônoma do mundo, renegando-o, e por causa da possibilidade de se confrontar o sistema hegeliano (SCHAFF, 1967).

No entanto, Marx se demarca do materialismo feuerbachiano e pensa o materialismo de forma diferente, o que trará implicações para fundamentar sua crítica ao materialismo mecânico, "burguês", naturalista, que exclui a História e seus processos, e para se perceber a incoerência nas procedências de ambos os materialismos. 
Schaff (1967, p. 63) deixa mais elucidativa essa crítica na reconstrução do percurso dos comentários de Marx nas Teses sobre Feuerbach:

1. Feuerbach é um materialista, cuja superioridade sobre outros baseia-se no fato de também tratar o homem de forma materialista, como objeto sensual.

2. A análise do homem, na perspectiva estreitamente naturalista, permite apenas compreendê-lo como exemplar de uma espécie biológica, mas não permite compreendê-lo como de fato existe e age na sociedade. O naturalismo de Feuerbach fica, em consequência, na expressão "o homem" e desconhece o homem real, concreto.

Nas relações inter-humanas, percebe somente amor e amizade.

3. A crítica da abstração, na compreensão do homem, liga-se, no fundo, a que Feuerbach só discute o homem sob o aspecto da espécie biológica, e não sob o aspecto dos lanços sociais entre os homens, bem como as condições de vida que o fazem ser o que é.

4. Feuerbach compreende o mundo contemplativo dos homens, e não o conjunto de ações que criam este mundo.

5. O naturalismo de Feuerbach fica, por conseguinte, perplexo em face de todos os problemas sociais e refere-se a princípios e ideias, mas não leva em conta as ações dos homens, responsáveis pela transformação da realidade. Feuerbach é obrigado a recorrer ao idealismo, ao tratar da História. E quando é materialista, o seu materialismo está separado da História.

Nessa crítica, Marx identifica, então, as deficiências da antropologia filosófica de Feuerbach e as restrições de seu materialismo em específico. Trata-se de limitações que se dão em função de um antropologismo que não respeitava a dimensão social e histórica na concepção de indivíduo, a partir de um estreito naturalismo sensualista (SCHAFF, 1967). Segundo Marx (1999, p. 11), "Feuerbach quer objetos sensíveis - realmente distintos dos objetos do pensamento: mas não apreende a própria atividade humana como atividade objetiva" (Grifo do autor). Mais à frente, complementa essa afirmação através da seguinte abstração:

(...) ele (Feuerbach) concebe o homem apenas como "objeto sensível" e não como "atividade sensível", pois ainda permanece no reino da teoria e não concebe os homens em sua conexão social dada, em suas condições de vida existentes, que fizeram dele o que são; por isto mesmo, jamais chega até os homens ativos realmente existentes, mas se detém na abstração "o homem" e apenas consegue reconhecer sentimentalmente o "homem real, individual, corporal", isto é, não conhece outras "relações humanas" "entre o homem e o homem" senão as do amor e da amizade, sendo estas, além disso, idealizadas. (MARX, 1999, p. 69)

Nesse sentido, Feuerbach torna abstrato o homem real e ignora o fato de o homem ser produto de ações em meio a condicionantes sócio-históricos.

Lukács (2012), por sua vez, comenta sobre a duplicidade do julgamento de Marx sobre Feuerbach, assinalando outras nuances que também sofreram críticas marxianas. “(...) o reconhecimento de sua virada ontológica como o único ato filosófico sério desse período e, ao 
mesmo tempo, a constatação de seu limite, ou seja, do fato de que o materialismo feuerbachiano nem mesmo se deu conta do problema da ontologia do ser social" (Ibidem, p. 283). A postura crítica acerca das apreciações de Feuerbach sobre a ontologia da natureza e sua atitude antirreligiosa permite que Marx avance. Ele reposiciona os problemas da natureza para uma ontologia completamente nova e desmistifica a relação abstrata entre Deus e o ser humano diante da necessidade de se observar as relações humanas na história social.

(...) no que se refere à filosofia da natureza, ele sempre se posicionou rigorosamente contra a tradicional superação entre natureza e sociedade, que Feuerbach tampouco havia superado, e sempre considerou os problemas da natureza, predominantemente, do ponto de vista de sua inter-relação com a sociedade. É por isso que o contraste com Hegel vai nele ganhando acentos mais vigorosos do que no próprio Feuerbach. Marx reconhece apenas uma só ciência, a ciência da história, que engloba tanto a natureza quanto o mundo humano. No que se refere à religião, não se contentou com a relação abstrato-contemplativa entre homem e Deus; à ontologia simplista de Feuerbach, malgrado seu caráter intencionalmente materialista, Marx contrapôs a exigência de levar em conta, de modo concreto e materialista, todas as relações da vida humana e, antes de tudo, as relações histórico-sociais. (LUKÁCS, 2012, p. 285)

Pois assim sendo, nessa agitação de tensionamento com Feuerbach e Hegel, Marx dá os contornos de sua perspectiva materialista. E esta perspectiva está para além da incompreensão existente a respeito dela. Supõe-se que o materialismo de Marx seja uma teoria psicológica atinente aos impulsos e paixões do homem na qual a motivação principal seja ganhar dinheiro e ter mais conforto material (FROMM, 1975). Diante disso, a materialidade sofre uma distorção semântica ao estar associada ao sentido de "ter" e não de “ser". Marx não propõe um materialismo econômico-hedonista, mas, sim, um materialismo histórico. Ele é um materialista em ontologia.

Schaff (1967, p. 64) explora dois elementos que se sobressaem na citada crítica ao naturalismo de Feuerbach para a apreensão do materialismo no qual se baseia a concepção marxista de homem:

a) a relação social do indivíduo, por pertencer a determinados grupos sociais dentro das relações inter-humanas como também

b) a compreensão do mundo como produto da atividade humana, e como este mundo cria, por seu lado, o homem, a compreensão de autocracia do homem social por intermédio da práxis social. (Grifos do autor)

Embora Feuerbach tenha promovido um avanço ao questionar as opiniões idealista, teocêntrica e heterônoma, a partir de sua concepção naturalista de homem, ele deixa brechas acerca do indivíduo social ao reduzir o status ontológico do homem a um exemplar da espécie biológica. “'Ser homem’ significa, aqui, certo grupo de propriedades abstratas que deveria 
existir em todos os indivíduos, no sentido de que compete aos indivíduos, como membros de uma determinada classe de elementos" (SCHAFF, 1967, p. 64). De modo restrito e unilateral, ele vê apenas o lado biológico do ser.

Marx, por outro lado, realça no status ontológico a condição do ser humano de uma totalidade que se constitui por suas propriedades biológicas, mas, determinantemente, por aquelas sócio-históricas que caracterizem a espécie humana.

\begin{abstract}
A concepção do indivíduo altera-se, na verdade, de forma simultânea, com a introdução do fator social de maneira qualitativa, tornando-se concreta, comparada à abstração da concepção puramente biológica, que não levava em conta a relação social do homem. O homem, além de um produto da evolução biológica das espécies, é um produto histórico, um produto de certa forma mutável nas diversas etapas da evolução da sociedade, conforme pertença a uma ou outra das classes e camadas da mesma sociedade. (SCHAFF, 1967, p. 65; Grifos do autor)
\end{abstract}

Quando se considera apenas a esfera biológica na determinação do ser, nega-se o caráter social que está atrelado ao status da ontologia do ser social, uma vez que este é partícipe de relações entre os homens em condições sociais e históricas particulares que determinam o que ele é e como ele é. Portanto, ele é, igualmente, num movimento de reciprocidade, o produto e o produtor da sociedade.

\begin{abstract}
A descoberta de Marx, estreitamente ligada à evolução do materialismo histórico, de acordo com a qual o indivíduo humano seria parte de uma sociedade, entrelaçado em relações inter-humanas concretas - em particular, em condições de produção - e criado por elas, é também genial em sua simplicidade, embora ainda não banal em seu significado, mesmo em nosso tempo. (SCHAFF, 1967, p. 65-66; Grifos meus)
\end{abstract}

Nesse sentido, a descoberta de Marx traz um indivíduo que surge sempre como indivíduo social e produtivo, e que existe como uma totalidade das condições sociais. Por outro lado, a concepção de homem não pode ser baseada apenas na afirmação geral de que o homem integra tanto a natureza como também a sociedade, pois ela deve supor a concretização da estrutura sociopsicológica do indivíduo humano (SCHAFF, 1967).

O peso das reflexões, todavia, deve sobrepor às noções abstratas e indeterminadas e residir na concretude dos indivíduos humanos reais. Ou seja, suas condições de existência por meio das quais eles estabelecem sua estrutura produtiva e as relações relativas a ela de modo a produzir socialmente a vida material. É nessa concretude que se encontram as múltiplas determinações do ser social.

Partimos da concepção do indivíduo humano real, e a sua análise social deveria revelar-nos o conjunto de condições de que partimos para a reconstrução espiritual e 
o citado concreto. Marx disse, em forma abreviada, que a essência dos homens equivale à soma das condições sociais. Preocupava-se, então, em saber porque determinadas ideias e concepções caracterizavam um homem, formado sob determinadas condições sociais. (SCHAFF, 1967, p. 69)

Não há qualquer êxito da operacionalidade de uma concepção especulativa de homem como a do naturalismo. A abstração do indivíduo é extinta na afirmativa de que a essência humana equivale à soma das condições sociais: o indivíduo como totalidade dessas condições. "Marx afirma, com amplitude bem maior, que o homem é um produto da sociedade, ou seja: ele é, como é, a obra da sociedade" (SCHAFF, 1967, p. 70; Grifos do autor). De tal modo, um ser que existe como um exemplar da espécie humana e como indivíduo, que é um produto do desenvolvimento histórico e, tão logo, um produto social.

Como, destarte, as condições sociais criam os homens? A resposta desta pergunta está na influência mútua entre a infra e a supraestrutura.

\begin{abstract}
O homem nasce numa determinada sociedade, sob determinadas condições sociais e inter-humanas que ele próprio não escolhe; são elas o resultado da atividade de gerações anteriores. No fundamento dessas - e não de outras - condições, cuja base são as condições de produção, ergue-se toda a complicada estrutura de concepções, sistemas de valores e instituições ligadas a ela. A opinião do que é bom e mau, do que é digno ou não, quer dizer, o determinado sistema de valores, é dado socialmente, igualmente como o conhecimento do mundo, que é determinado pelo desenvolvimento histórico da sociedade. As condições sociais formam, com a ajuda da consciência social vigente, o indivíduo humano, que nasce e se desenvolve numa determinada sociedade. É neste sentido que as condições criam o indivíduo. (SCHAFF, 1967, p. 71; Grifos meus)
\end{abstract}

Essas condições sociais da autogênese são reguladas, pois, pelas relações que os homens estabelecem entre si e com a natureza. Essas relações mais gerais podem ser expressas de modo elementar, natural e genérico na relação entre o homem e a mulher.

Nesta relação natural dos gêneros, a relação do homem com a natureza é imediatamente sua relação com o homem, do mesmo modo que a relação com o homem é imediatamente sua relação com a natureza, sua própria destinação natural. Nesta relação aparece, pois, de maneira sensível, reduzida a um fato visível, em que medida a essência humana se converteu para o homem em natureza ou a natureza tornou-se a essência humana do homem. A partir desta relação, pode-se julgar o grau de cultura do homem em sua totalidade. Do caráter desta relação deduz-se a medida em que o homem converteu-se em ser genérico, em homem, e se apreendeu como tal; a relação do homem com a mulher é a relação mais natural do homem com o homem. Nela se mostra em que medida o comportamento natural do homem tornou-se humano ou em que medida a essência humana tornou-se para ele essência natural, em que medida a sua natureza humana tornou-se para ele natureza. Mostrase também nesta relação a extensão em que o carecimento (Bedürfnis) do homem se tornou carecimento humano, em que extensão o outro homem enquanto homem converteu-se para ele em carecimento; em que medida ele, em seu modo de existência mais individual, é, ao mesmo tempo, ser coletivo. (MARX, 1974, p. 7-8; Grifos do autor) 
Marx revela o caráter social do homem na efetivação e na tomada de consciência da sua essência enquanto tal. O processo de humanização decorre da adequação do indivíduo às riquezas das objetivações produzidas historicamente, ou seja, a cultura como forma afirmativa da generalidade do ser social. Nota-se também que, a partir dessa relação dos gêneros, está posta a necessidade mais imediata do mundo dos homens: o carecimento do outro. O retorno do a si enquanto homem social, isto é, humano.

Marx (1974) traz que a propriedade posta na sociabilidade é o caráter mais geral do movimento de existência do ser genérico determinado "em-si" e "para-si". Tanto o objeto como o sujeito são resultados da exteriorização e na materialização imediatamente na sociedade efetiva com outros homens. Um movimento de produção de reciprocidade: a sociedade produz os homens e estes a produzem e reproduzem-na. Nessa acepção, funda-se a alegação de que o caráter social se dá em função da atuação como homem.

\begin{abstract}
A essência humana da natureza não existe senão para o homem social, pois apenas assim existe para ele como vínculo com o homem, como modo de existência sua para o outro e modo de existência do outro para ele, como elemento vital da efetividade humana; só assim existe como fundamento de seu próprio modo de existência humano. Só então se converte para ele seu modo de existência natural em seu modo de existência humano, e a natureza torna-se para ele o homem. A sociedade é, pois, a plena unidade essencial do homem com a natureza, a verdadeira ressurreição da natureza, o naturalismo acabado do homem e o humanismo acabado da natureza. (MARX, 1974, p. 9; Grifos do autor)
\end{abstract}

A condição do indivíduo como ser social rompe com qualquer possibilidade de tensão entre o indivíduo e a sociedade. A singularidade, a individualidade do homem se exterioriza e se confirma na e para a vida social constituindo a totalidade da realidade. As obras humanas resultam das singularidades e formam a generalidade do ser humano.

A vida individual e a vida genérica do homem não são distintas, por mais que,
necessariamente, o modo de existência da vida individual seja um modo mais
particular ou mais geral da vida genérica, ou quanto mais a vida genérica seja uma
vida individual mais particular ou geral. [...] O homem - por mais que seja um
indivíduo particular, e justamente é sua particularidade que faz dele um indivíduo e
um ser social individual efetivo - é, na mesma medida, a totalidade, a totalidade
ideal, o modo de existência subjetivo da sociedade pensada e sentida para si, do
mesmo modo que também na efetividade ele existe tanto como intuição e gozo
efetivo do modo de existência social, quanto como uma totalidade de exteriorização
de vida humana. (MARX, 1974, p. 10; Grifos do autor)

De tal maneira, é partindo do homem real e das condições econômicas e sociais em que ele tem de viver, que Marx revela o substrato da História. 


\subsubsection{A concepção de história: a consubstanciação dos atos humanos}

A concepção marxista de História é decidida na tese de que os atos humanos compõem sua processualidade. A História é o ato de nascimento do homem que é, para ele, uma história consciente. Ao ser dotado de consciência, esse ato se supera. "A história é a verdadeira história natural do homem" (MARX, 1974, p. 41). Contudo, esse ato de geração do homem na história não é entendido da mesma maneira que na estreita perspectiva histórica hegeliana. Longe de ser a história efetiva do homem como sujeito ativo, Hegel apenas encontrou a expressão abstrata, lógica, especulativa para o movimento da história com ações imaginárias de sujeitos imaginários em que as formas de consciências ganham a aparência de autonomia e determinação (MARX, 1974; 1999, p. 55-56).

Esta concepção de história consiste, pois, em expor o processo real de produção, partindo da produção material da vida imediata; e em conceber a forma de intercâmbio conectada a este modo de produção e por ele engendrada (ou seja, a sociedade civil em suas diferentes fases) como o fundamento de toda a história, apresentando-a em sua ação enquanto Estado e explicando a partir dela o conjunto dos diversos produtos teóricos e formas da consciência - religião, filosofia, moral etc.** - assim como em seguir seu processo de nascimento a partir desses produtos; o que permite então, naturalmente, expor a coisa em sua totalidade (e também, por isso mesmo, examinar a ação recíproca entre estes diferentes aspectos). Não se trata, como na concepção idealista da história, de procurar uma categoria em cada período, mas sim de permanecer sempre sobre o solo da história real; não de explicar a práxis a partir da ideia, mas de explicar as formações ideológicas a partir da práxis material; chegando-se, por conseguinte, ao resultado de que todas as formas e todos os produtos da consciência não podem ser dissolvidos por força da crítica espiritual, pela dissolução na "autoconsciência" ou pela transformação em "fantasmas", "espectros", "visões" etc. - mas só podem ser dissolvidos pela derrocada prática das relações reais de onde emanam estas tapeações idealistas; não é a crítica, mas a revolução a força motriz da história, assim como da religião, da filosofia e de qualquer outro tipo de teoria. Tal concepção mostra que a história não termina dissolvendo-se na "autoconsciência", como "espírito do espírito", mas que em cada uma de suas fases encontra-se um resultado material, uma soma de forças de produção, uma relação historicamente criada com a natureza e entre os indivíduos, que cada geração transmite à geração seguinte; uma massa de forças produtivas, de capitais e de condições que, embora sendo em parte modificada pela nova geração, prescreve a esta suas próprias condições de vida e lhe imprime um determinado desenvolvimento, um caráter especial. Mostra que, portanto, as circunstâncias fazem os homens assim como os homens fazem as circunstâncias. Esta soma de forças de produção, de capitais, de formas sociais de intercâmbio, que cada indivíduo e cada geração encontram como algo dado, é o fundamento real daquilo que os filósofos representaram como "substância" e "essência do homem"; (...). (Grifo do autor)

É a História que, em seu desenrolar, favorece, ou não, a genuína efetivação das potencialidades intrínsecas e reais da essência do homem no processo de produção de sua vida material. "Tal como os indivíduos manifestam sua vida, assim eles são. O que eles são 
coincide, portanto, com sua produção, tanto com o que produzem, como com o modo como produzem. O que os indivíduos são, portanto, depende das condições materiais de sua produção" (MARX, 1999, p. 28; Grifos do autor). O primeiro ato histórico é, assim, a produção dos meios de vida dos homens, o que garante sua existência.

De tal forma, a primeira condição prévia de toda a História da humanidade é a existência de indivíduos vivos que são os criadores e os personagens da História, recusando o ser passivo com seu papel determinista e coadjuvante.

\begin{abstract}
(...) toda a assim chamada história universal nada mais é do que a produção do homem pelo trabalho humano, o vir-a-ser da natureza para o homem tem assim a prova evidente, irrefutável, de seu nascimento de si mesmo, de seu processo de origem. Ao ter-se feito evidente de uma maneira prática e sensível a essencialidade do homem na natureza; ao ter-se evidenciado, prática e sensivelmente, o homem para o homem como de existência da natureza e a natureza para o homem como o modo de existência do homem, tornou-se praticamente impossível perguntar por um ser estranho, por um ser situado acima da natureza e do homem - uma pergunta que encerra o reconhecimento da não-essencialidade da natureza e do homem. (MARX, 1974, p. 15; Grifos do autor)
\end{abstract}

Embora a própria história seja uma parte efetiva da história natural, da essência natural do homem, ela não coincide com os processos históricos naturais porque tem como fator determinante e interveniente a atividade humana consciente - o trabalho. É, assim, uma História que se "conta" materialmente e que é posta em movimento a partir da produção material da vida social.

\begin{abstract}
A interpretação "materialista" ou "econômica" da História feita por Marx nada tem a ver, absolutamente, com um suposto anelo "materialista" ou "econômico" considerado como o impulso mais fundamental do homem. Ela significa que o homem, o homem real e total, os "indivíduos vivos reais" - e não as ideias produzidas por estes "indivíduos" - são o tema da História e da compreensão das leis desta. De fato, a interpretação marxista da História pode ser denominada uma interpretação antropológica da História como se quisessem evitar ambiguidades dos termos "materialista" e "econômico"; ela é a compreensão da História baseada no fato de os homens serem "os autores e atores da sua história". (FROMM, 1975, p. 23; Grifos meus)
\end{abstract}

Marx parte do homem produtivo e ativo que faz sua história, cuja descrição deve ser feita pelo metabolismo homem e natureza, quando ele, para produzir seus meios de subsistência, modifica as bases naturais. Por esses meios de subsistência, com vistas ao atendimento das necessidades imediatas, os homens estão produzindo as condições materiais para a sua existência. 
O homem dá a luz a si próprio no decurso da História. O fator essencial deste processo de criação da raça humana está na sua relação com a natureza. O homem, na alva da História, está cegamente vinculado ou agrilhoado à natureza. Com o correr da evolução, ele transforma sua relação com a natureza e, por conseguinte, consigo mesmo. (FROMM, 1975, p. 25)

Em suma, Marx (1999) aponta quatro aspectos das relações históricas originárias que condicionam a história propriamente dita:

1) os homens devem ter condições para "fazer história" - o primeiro ato histórico, como indicado anteriormente, é a atividade de produção dos meios de vida que permitem a satisfação das necessidades mais gerais, a produção da própria vida material;

2) o atendimento a estas necessidades conduz a produção de novas necessidades;

3) a criação de outros homens - a procriação, a perpetuação da espécie - nas relações de família que engendram e ampliam novas relações sociais e necessidades;

4) a produção da vida, tanto da própria, no trabalho, como da alheia, na procriação, se apresenta como dupla relação: natural e social. É, neste sentido, pois, que a história se consubstancia nos atos humanos, haja vista o permanente movimento de vir-a-ser do homem ao produzir e reproduzir as condições materiais de sua vida diante da satisfação de necessidades que surgem em determinadas circunstâncias históricas e sociais a partir das relações humanas e com a natureza.

Entendendo-se que o fundamento da história se aplica ao modo de produzir e a configuração de intercâmbio a ele conectada, as mudanças dessa história são impulsionadas por uma contradição posta no desenvolvimento social, porque as relações inter-humanas existentes se encontram em contradição com as forças de produção existentes. É, pois, um momento de crise no âmbito da estrutura produtiva. Quando um sistema de produção ou organização social prejudica as forças produtivas, esta organização deverá procurar um modo de produção mais adequado ao conjunto de forças produtivas de maneira a desenvolvê-las (FROMM, 1975).

A evolução do homem com toda a história caracteriza-se pela luta do homem contra a natureza. Em certo ponto da História (de acordo com Marx, em futuro próximo), o homem terá desenvolvido as forças produtivas da natureza a tal ponto que o 
antagonismo entre ele e a natureza poderá ser, afinal, solucionado. Nesse ponto, “a pré-história do homem” terminará e principiará a história verdadeiramente humana. (FROMM, 1975, p. 28)

Em outras palavras, em uma estrutura produtiva menos contraditória e antagônica, a história verdadeira humana estará na reconciliação do homem consigo mesmo, com a natureza e com seu semelhante, pautando-se no fato de o homem gerar a si próprio no decorrer da História.

Não obstante, Schaff (1967) demonstra que a identificação da História com a atividade humana consciente proporciona um tratamento materialmente concreto de Marx enquanto respostas aos questionamentos que afligem a autonomia da relação entre o indivíduo como "criador" e a História. O que se sanciona é a consubstanciação de atos de homens compreendidos em sua caracterização de condicionados pela composição da sociabilidade e subordinados às regularidades objetivas da evolução histórica agindo de modo intencional um exercício de racionalidade e de complexidade. Esses atos humanos levam a escolhas dentre as diversas alternativas que possuem na elaboração do mundo objetivo, o que pressupõe ações conscientes e úteis desses indivíduos. Assim sendo,

O marxismo rejeita a metafísica personalista e existencialista da concepção de um ser autônomo do indivíduo, ao passo que reconhece a propriedade física e a irrepetibilidade da estrutura psicofísica do indivíduo humano, que o torna um microcosmo. O marxismo confirma o que é essencial para a concepção do ser autônomo do indivíduo, e rejeita as premissas místicas e suas implicações. (SCHAFF, 1967, p.159)

Marx nega, portanto, uma possível fluência natural da evolução histórica ou que esta esteja à mercê de forças exteriores e de razões subjetivas de sujeitos apartados de seu meio social. Ele não ignora a importância da subjetividade dos indivíduos, mas aponta para as determinações sociais.

\footnotetext{
O homem é, por conseguinte - segundo o marxismo - o criador da História, não como mônade da livre vontade, condicionada por nada, o que seria uma simples fantasia filosófica, mas como produto da História, e, em consequência, como indivíduo psicofísico real, socialmente condicionado, que faz as suas determinadas escolhas. (SCHAFF, 1967, p.165; Grifos do autor)
}

Embora esteja passível de influências sociais, são a reflexão consciente, a capacidade de estabelecer análise e a leitura da realidade, percebendo as opções que se tem, que conferem ao homem o título de escolha livre. Trata-se do lugar onde se realiza a liberdade do indivíduo: 
ele faz sua escolha e, então, movimenta a objetividade histórica a partir de suas necessidades e promovendo transformações na realidade concreta.

\begin{abstract}
Uma liberdade assim entendida não é, pois, absoluta, mas a esfera da liberdade, "relacionada" à relatividade da personalidade dos homens, de qualquer forma é imensa. Determina ela, igualmente, se podemos considerar o homem - a criação da História - como criador da História. Sem dúvida, podemos dizer que o homem é tanto mais livre, quanto mais consciente for a escolha das ações, orientadas para um determinado objetivo. E isto mesmo, se a escolha for feita com base no conhecimento, indispensável para uma determinada orientação do desenvolvimento, portanto, se a escolha livre se baseia no fato de ele subordinar-se, de maneira consciente, à necessidade. Não interessa que a escolha feita pelo homem não seja condicionada por nada, mas que seja consciente e não imposta por forças exteriores. A liberdade do homem não se obtém na medida de seu isolamento em si próprio e de seu desprendimento dos condicionamentos sociais (o que aliás é uma ficção), e sim na medida da sua consciência dos objetivos e caminhos a aspirar pela escolha de ações correspondentes. A liberdade do indivíduo, assim compreendida, está em contradição com a espontaneidade da evolução histórica, e não com seu caráter objetivo (no sentido da independência da vontade dos diferentes indivíduos). Aqui se expressa, entretanto, com clareza, a concepção da liberdade como necessidade reconhecida. (SCHAFF, 1967, p. 163-164; Grifos meus)
\end{abstract}

Dessa forma, segundo Schaff (1967), o homem é livre na medida em que tem essa ou aquela alternativa em uma determinada ação. Todavia, perde essa propriedade quando está privado de possibilidades de escolha.

Nesse sentido de apontar circunstâncias nas quais o homem não exerce sua liberdade, Marx traz uma exemplificação no trecho abaixo:

\begin{abstract}
O homem faz da sua atividade vital mesma um objeto da sua vontade e da sua consciência. Ele tem atividade vital consciente. Esta não é uma determinidade com a qual ele imediatamente coincide. A atividade vital consciente distingue o homem imediatamente da atividade vital animal. Justamente, [e] só por isso, ele é um ser genérico. Ou ele somente é um ser consciente, isto é, a sua própria vida lhe é objeto, precisamente porque é um ser genérico. Eis porque a sua atividade é livre. O trabalho estranhado inverte a relação a tal ponto que o homem, precisamente porque é um ser consciente, faz da sua atividade vital, da sua essência, apenas um meio para sua existência. (MARX, 2002-2003, p. 464; Grifos do autor)
\end{abstract}

Aqui ele discute o contexto da sociabilidade burguesa, que age determinantemente sobre a atividade vital humana, ou seja, o trabalho. Ela converte tal atividade em alienada, estranhada, tornando-a apenas um meio para subsistência e sua potencialidade fica "presa" às demandas do capitalista: "Se ele (o trabalhador) se relaciona com a sua própria atividade como uma [atividade] não-livre, então ele se relaciona com ela como a atividade a serviço de, sob o domínio, a violência e o julgo de um outro homem” (MARX, 2002-2003, p. 467).

\title{
1.1.3. O trabalho: a maneira como o homem transforma e regula a natureza
}


O trabalho revela-se como o elemento analítico e explicativo imprescindível para a compreensão da teoria da ontologia do ser social situando seu significado e sentido ontológico na humanização, e a gênese das peculiaridades do homem a partir do seu ser social.

O trabalho como protoforma da atividade humana social está posto como o permanente processo de objetivação do ser social, instituindo a objetividade sócio-histórica do gênero humano em que, para concretizar sua existência, o ser social objetiva-se ao se defrontar com as demandas e circunstâncias às quais ele dá respostas diante das alternativas que tem. “(...) a essência do trabalho humano está no fato de que, em primeiro lugar, ele nasce em meio à luta pela existência e, em segundo lugar, todos os seus estádios são produtos da autoatividade do homem" (LUKÁCS, 2013, p. 2). Desse jeito, o trabalho possibilita a produção dos bens materiais imprescindíveis à vida do homem e à plena realização das singularidades, mas também da totalidade social, isto é, de sua generalidade por meio de determinações e mediações estabelecidas no desenvolvimento de sociabilidades que se infligem na processualidade histórica.

Cabe salientar, por outras colocações, que o trabalho é a objetivação principal e necessária do ser social, apesar de que ela, a objetivação humana, não se restrinja ou se consuma apenas no ato de trabalho. "Quanto mais se desenvolve o ser social, mais suas objetivações transcendem o espaço ligado diretamente ao trabalho. No ser social desenvolvido, verificamos a existência de esferas de objetivações que se autonomizam das exigências imediatas do trabalho (...)" (PAULO NETTO; BRAZ, 2007, p. 43; Grifos do autor). As outras expressões de objetivações guardam afinidades intrínsecas ao trabalho por supor características inerentes a ele (a atividade teleologicamente orientada, a tendência à universalização e a linguagem articulada).

\footnotetext{
Assim, o trabalho se torna o modelo de toda práxis social, na qual, com efeito mesmo que através de mediações às vezes muito complexas - sempre são transformadas em realidade posições teleológicas, em termos que, em última análise, são materiais. (...) há uma essencial afinidade ontológica e esta brota do fato de que o trabalho pode servir de modelo para compreender as outras posições socioteleológicas exatamente porque, quanto ao ser, ele é a forma originária. (LUKÁCS, 2013, p. 4)
}

Tão logo, no conjunto de objetivações humanas, a práxis, no limite de suas particularidades e distinções que ocasionam um alheamento progressivo entre elas, o trabalho, como objetivação primária, é a parte volvida para a regulação, controle e exploração da natureza em que o homem é o sujeito e a natureza o objeto, resultando especificamente algo 
material (PAULO NETTO; BRAZ, 2007). Põe-se daí, então, a afirmativa de o trabalho ser o meio que viabiliza o metabolismo entre sociedade e natureza, historicamente determinado, produzindo as condições materiais de manutenção e reprodução desta sociedade e sendo o eixo a partir do qual a vida social se organiza.

Contudo, no processo de trabalho, que situa o homem para além da natureza e o caracteriza como ser social, tem-se ainda a efetivação da constituição do indivíduo social por sua ação na transformação intencional da natureza em um duplo movimento criativo, fazendo referência ao próprio modo de ser dos homens e da sociedade: o homem é produto e criação da sua autoatividade e se define a partir do ato de produzir sua existência.

Um primeiro ponto diz respeito ao fato de a atividade de trabalho ser específica ao gênero humano e consistir, em sua forma basal, na transformação da materialidade natural em materialidade social. Essa atividade não é apenas uma simples adaptação ao meio ou a apropriação da natureza para a criação de valores de uso de matérias naturais adaptadas às necessidades humanas mais primordiais. Essa atividade social se distingue por seu caráter histórico de transformar, produzindo os meios de sua subsistência: os instrumentos mais adequados para o processo de trabalho. Nessa direção, a criação e a utilização dos instrumentos implicam necessariamente que o homem tenha domínio de si mesmo, domínio este que se dá por meio da consciência sobre o elemento instintivo puramente biológico, uma vez que "O homem deve pensar seus movimentos expressamente para aquele determinado trabalho e executá-los em contínua luta contra aquilo que há nele de meramente instintivo, contra si mesmo" (LUKÁCS, 2013, p. 22). Esse domínio abarca ainda os limites estreitos do câmbio com a natureza na medida em que ele acontece cada vez mais mediante a práxis global e, em particular, ao trabalho.

Atividades com vistas a sanar as carências elementares de sobrevivência são comuns entre as espécies animais. Porém, diferente do que ocorre com os homens, elas acontecem instintivamente, dadas a priori ou inatas, na fronteira de um legado subjugado a propriedades, legalidades e determinismos orgânico-naturais numa relação imediata entre o animal e seu ambiente.

É verdade que o animal também produz. Constrói para si um ninho, habitações, como a abelha, castor, formiga, etc. No entanto, produz apenas aquilo de que necessita imediatamente para si ou para sua cria; produz unilateral[mente], enquanto o homem produz universal[mente]; o animal produz apenas sob o domínio da carência física imediata, enquanto o homem produz mesmo livre da carência física, e só produz, primeira e verdadeiramente, na [sua] liberdade [com relação] a ela; o animal só produz pra si mesmo, enquanto o homem reproduz a natureza inteira; [no animal,] o seu produto pertence imediatamente ao seu corpo físico, enquanto que o 
homem se defronta livre com o seu produto. O animal forma apenas segundo a medida e a carência da espécie à qual pertence, enquanto que o homem sabe produzir segundo a medida de qualquer espécie, e sabe considerar, por toda parte, a medida inerente ao objeto; o homem também forma, por isso, segundo as leis da beleza (Schonheit). (MARX, 2002-2003, p. 464)

O trabalho humano conforma um novo padrão de atividade, exclusiva ao homem, que o individualiza de qualquer outra atividade ao romper com mecanismos e regularidades naturais (PAULO NETTO; BRAZ, 2007), convergindo para a crescente sociabilização entre os homens, tanto em nível de individualidade quanto de totalidade social.

Paulo Netto e Braz (2007) apontam três fatores acerca desse impulso de ruptura com o "natural": 1) na operacionalização do trabalho, o uso de instrumentos numa atuação que não se dá imediatamente sobre a matéria natural, sendo, assim, um intercâmbio mediado entre o sujeito e o objeto; 2) o trabalho não se efetiva sendo geneticamente determinado em função do nível de conhecimentos e habilidades transmissíveis entre os seres humanos por diversos aportes de sociabilização; 3) o trabalho não atende somente às necessidades primárias, uma vez que as formas desse atendimento variam e implicam o surgimento de novas necessidades que adquirem a qualidade de socioculturais e mais elevadas.

Em certa medida, Paulo Netto e Braz (2007) complementam a ideia desse ponto de vista explicando que o ser social se estrutura como um ser distinto das formações naturais, porque é capaz de consolidar atividades teleologicamente orientadas; objetivar-se material e idealmente; comunicar-se e expressar-se pela linguagem articulada; tratar suas atividades e a si mesmo de modo reflexivo, consciente e autoconsciente; escolher entre alternativas concretas; universalizar-se; e socializar-se. Sendo assim, "O ser social é a síntese dessas determinações estruturais" (Ibidem, p. 41). O seu desenvolvimento nota-se na historicidade da ação humana e constitui historicamente o ser dos homens.

Aquilo que é mais preponderante no trabalho como fenômeno humano-social: ele é uma atividade teleologicamente direcionada por seres conscientes, antecipando os resultados de sua atividade, na qual o ser humano viabiliza suas capacidades e forças essenciais.

Uma aranha executa operações semelhantes às do tecelão, e uma abelha envergonha muitos arquitetos com a estrutura de sua colmeia. Porém, o que distingue o pior arquiteto da melhor abelha é o fato de que o primeiro tem a colmeia em sua mente antes de construí-la com a cera. No final do processo de trabalho, chega-se a um resultado que já estava presente na representação do trabalhador no início do processo, portanto, um resultado que já existia idealmente. Isso não significa que ele se limite a uma alteração da forma do elemento natural; ele realiza neste último, ao mesmo tempo, seu objetivo, que ele sabe que determina, como lei, o tipo e o modo de sua atividade e ao qual ele tem que subordinar sua vontade. (MARX, 2013, p. 255-256; Grifos meus) 
Tangenciando, em suma, o que Lukács (2013) aponta sobre isso, é possível observar que uma categoria qualitativamente nova em relação às formas ontológicas precedentes do ser social - inorgânica e orgânica - é a realização adequada, ideada e desejada da posição teleológica. Uma consequência importante disso é o fato de a consciência humana, com o trabalho, deixar de ser, no concreto modo de ser de sua natureza, um epifenômeno. Outra centralidade é o fato de o fundamento ontológico-estrutural do processo de trabalho ser, pois, constituído pelas posições teleológicas e pelas séries causais que elas põem em movimento. E dentro dessa dinâmica emerge, então, uma nova categoria determinante, que faz a passagem da possibilidade à realidade: a alternativa. Ela oferece, assim, as precondições objetivas nas quais o ser social funda sua atividade social e os efeitos transformadores do pôr teleológico das causalidades.

Desse modo, em condições historicamente determinadas, o trabalho realizado pelos homens propiciou, no desenvolvimento do ser social, a partir do processo de humanização, o afastamento das barreiras naturais e tornou a satisfação de suas necessidades substancialmente sociais, pois, "quanto mais o homem se humaniza, quanto mais se torna social, tanto menos o ser natural é determinante em sua vida" (PAULO NETTO; BRAZ, 2007, p. 38). Uma satisfação que é, portanto, mediada (LUKÁCS, 2013). O avanço do processo de humanização colocado pelas vias do trabalho exige a diferenciação e a complexificação das objetivações do ser social e isso acaba por estabelecer a diminuição dos impactos da natureza. Todavia, conquanto haja essa atenuação, os limites naturais e a própria naturalidade dos homens são insuperáveis. Lukács (2013) confirma isso ao pontuar motivado por aquilo que Marx chamou de "recuo das barreiras naturais". Disse então que: "Por mais relevantes que sejam os efeitos transformadores do pôr teleológico das causalidades no processo de trabalho, a barreira natural só pode retroceder, jamais desaparecer inteiramente (...)” (Ibidem, p. 18).

Lukács (2013), em se tratando dessa inseparabilidade, traz também o contexto da linha evolutiva do ser social ligada à passagem da prevalência da esfera orgânica à sociabilidade em que há a alteração do ser orgânico em ser social, o que implica um salto, em termos ontologicamente necessários, com mudanças qualitativas e estruturais do ser. Atribui, então, ao trabalho, um lugar privilegiado no processo e no salto da gênese do ser social, justificando esta atribuição com o seguinte argumento: 
primitivas, pressupõem o salto como já acontecido. Somente o trabalho tem, como sua essência ontológica, um claro caráter intermediário: ele é, essencialmente, uma inter-relação entre homem (sociedade) e natureza, tanto inorgânica [utensílio, matéria-prima, objeto do trabalho, etc.] como orgânica, inter-relação que pode até estar situada em pontos determinados da série a que nos referimos, mas antes de mais nada assinala a passagem, no homem que trabalha, do ser meramente biológico ao ser social. (LUKÁCS, 2013, p. 2)

Isso significa enfatizar o movimento de superação qualitativa ontológica das esferas inorgânica e orgânica em razão da efetivação do processo de trabalho, o momento predominante de ruptura com as outras esferas ontológicas, de onde derivam as determinações que constituem a essência das especificidades do ser social e o particulariza pela incessante produção do novo - a incorporação de novas objetivações ao mundo dos homens - por meio da transformação do mundo objetivo que o cerca de maneira conscientemente orientada, teleologicamente posta.

A transformação consciente orientada do real se constitui no momento predominante do salto que envolve a geração do ser social, uma nova forma de ser, que é a viabilidade da simultânea distinção e articulação das três esferas ontológicas. A possibilidade de existência do ser social só se confere mediante as esferas da natureza - a inorgânica (caracterizada pelo movimento no qual algo se transforma em um outro algo distinto; um tornar-se outro) e a orgânica (um permanente processo de reprodução do mesmo; reprodução biológica; uma processualidade "muda”) (LESSA, 2012).

Lukács (1978) cita que a captação da especificidade do ser social só é passível de compreensão desde que se considere o surgimento e o desenvolvimento do ser social com a base de um ser orgânico e este de um ser inorgânico, não sendo possível eliminar as bases ontológicas naturais. Processa-se um salto entre uma forma de ser mais simples e a origem de uma nova forma de ser, mais complexa, por meio de categorias de transição. Após o salto, existe uma ocasião em que ocorre o aperfeiçoamento da nova forma de ser. Já foram desvendadas configurações preparativas de passagem de um tipo de ser a outro e reveladas as mais importantes categorias fundamentais das formas de ser mais complexas, as quais são opostas àquelas mais simples. “(...) a reprodução da vida em contraposição ao simples tornarse outra coisa; a adaptação ativa, com a modificação consciente do ambiente, em contraposição à adaptação meramente passiva etc" (LUKÁCS, 1978, p. 3). A nova forma é algo qualitativamente novo e sua constituição não pode apenas ser especulada da forma originária.

Conforme Lukács (1978), como protoforma dinâmico-estruturante do ser social, o trabalho, humano, neste caso, tem sua gênese no processo de reprodução orgânica. Essa forma 
de trabalho se distancia de formas mais "simples". Nessas situações, há uma inata capacidade de trabalhar ou nas quais a divisão do trabalho é resultado da diferenciação biológica dos exemplares da espécie, não influenciando como princípio ativo do desenvolvimento de um ser mais complexo ao conservar uma etapa de estagnação. A essência do trabalho está concentrada não no fato de fabricar algo, mas pela função exercida pela consciência, cuja representação não é mais a de epifenômeno da reprodução biológica. A consciência tem papel decisivo na demarcação materialista entre o ser da natureza orgânica e o ser social.

De acordo com Paulo Netto e Braz (2007), toda e qualquer sociedade deve sua reprodução ao seu envolvimento ininterrupto com a natureza. E o que se torna peculiar em cada formação socioeconômica é a maneira como essa interação é feita, porque se mudam os tipos e os meios empregados na transformação da natureza.

O que diferencia as épocas econômicas não é "o que" é produzido, mas "como", "com que meios de trabalho". Estes não apenas fornecem uma medida do grau de desenvolvimento da força de trabalho, mas também indicam as condições sociais nas quais se trabalha. (MARX, 2013, p. 257)

Discute-se, por assim dizer, a modificação, ao longo da história da humanidade, dos modos de produção material da vida social e, logo, das relações entre os homens e das condições reais nas quais eles vivem.

O trabalho é, então, atividade humana produtiva na qual há a realização das verdadeiras necessidades do homem e cuja satisfação é indispensável à efetivação de sua essência como ser humano que é, ao mesmo tempo, social e histórica. A essência do homem não é uma inerência a cada ente singular da espécie, mas ela é o conjunto das relações sociais (MARX, 1999). Em Marx, embora os conceitos de natureza e de essência possam ter sido abordados distintamente em sua trajetória intelectual, ora equivocadamente, ora com múltiplos sentidos, os seus empregos não foram remetidos a uma noção abstrata e nãohistórica (FROMM, 1975).

A natureza humana, em Marx, não é exclusivamente biológica, nem tampouco uma abstração, porque

(...) ela só pode ser interpretada historicamente, porque se revela na História. A natureza (essência) do homem pode ser inferida de suas múltiplas manifestações (e deturpações) na História; não pode ser vista como tal, como uma entidade de existência estática "por trás" ou "acima" de cada homem per si, mas como a existente em cada homem como uma potencialidade, revelando-se e modificando-se através do processo histórico. (FROMM, 1975, p. 78; Grifo do autor) 
O homem não é produto da natureza, ele não tem uma natureza imutável e dada ao nascer, posta a priori, mas se altera historicamente e está envolto pela função das condições sociais (SCHAFF, 1967).

Diferente de muitos sociólogos e psicólogos contemporâneos, Marx descrê em algo como uma natureza natural, uma folha em branco na qual a cultura escreve seu texto. Pelo contrário, a ideia principia do fato de que o ser humano poder ser cognoscível, palpável e verificável, sendo definido em seus vários enfoques. Ele fala em duas naturezas humanas, uma mais geral, e outra modificada de cada época histórica. Uma natureza que guarda as determinações mais gerais do ser social ligada aos impulsos e apetites fixos, e outra, atrelada aos relativos, que se transforma em concordância com as diversas circunstâncias sóciohistóricas, ou seja, é expressão específica da natureza humana em cada cultura (SCHAFF, 1967; FROMM, 1975).

O potencial do homem, para Marx, é um potencial dado; o homem é, por assim dizer, a matéria-prima humana que, como tal, não pode ser modificada, tal como a estrutura do cérebro tem permanecido a mesma desde a aurora da história. Contudo, o homem de fato muda no decurso da história; assim como ele faz a história, ele é seu próprio produto. A História é a história da autorrealização do homem; ela nada mais é que a autocriação do homem por intermédio de seu próprio trabalho e produção. (FROMM, 1975, p. 36)

Ancorado em Hegel, Marx concebe seu conceito marxista de homem, cujo princípio está na tensão entre essência e existência. “Ou, por outras palavras, é o problema da relação essência e existência. No processo de existência, a essência se realiza e, ao mesmo tempo, existir significa um retorno à essência" (FROMM, 1975, p. 36). Isso significa que a apropriação do mundo requer a ação humana, quando o homem faz deste mundo o seu, o mundo dos homens, e nisso está a realização da autoconsciência do homem, a consciência para si, momento em que o retorno a si mesmo transforma-se em essência. A existência é a realização da essência. Portanto, "A essência pode "alcançar" sua existência quando as potencialidades das coisas tiverem amadurecido nas e através das condições da realidade" (FROMM, 1975, p. 37). Potencialidades estas que são intrínsecas e que se manifestam no movimento constante de vir-a-ser do homem. Esta é, pois, a expressão histórica e ontológica da essência do homem.

Realça-se, assim, a produtividade humana. O indivíduo livre e produtivo, que, só ao ser produtivamente ativo em sua relação com o mundo, faz sua apreensão tornando-o seu. 
Para Spinoza, Goethe, Hegel, assim como para Marx, o homem está vivo na medida em que é produtivo, na medida em que abarca o mundo exterior no ato de manifestar seus próprios poderes humanos específicos e de abarcar o mundo com eles. $\mathrm{Na}$ medida em que o homem não é produtivo, na medida em que é receptivo e passivo, ele nada é, está morto. Neste processo produtivo, o homem realiza a sua própria essência, retorna à sua própria essência, o que, em linguagem teológica, nada mais é que o retorno a Deus. (FROMM, 1975, p. 38)

Sobre isso, Fromm (1975) alerta que, para a compreensão do conceito marxista de atividade, é preciso captar seu entendimento da relação sujeito e objeto. Sinteticamente, Marx problematiza a separação entre sujeito e objeto, visto que, ao interagir com o mundo objetivo, o homem se humaniza.

O mundo torna-se real para o sujeito que estabelece com ele uma relação humana. Tem-se, assim, uma natureza humanizada. O homem, ao se relacionar humanamente com o mundo objetivo, supera a alienação de si mesmo, o que representa o regresso do próprio homem como um ser social. O processo de humanização é, pois, desencadeado pela exterioridade em que o dado primário ontológico é a realidade.

Esta relação ativa com o mundo objetivo é denominada por Marx "vida produtiva". É vida criando vida. No tipo de atividade da vida reside todo o caráter da espécie, seu caráter como espécie; e a atividade livre e consciente é o caráter da espécie dos seres humanos. O que Marx tem em mente como "caráter de espécie" é a essência do homem; é o que é universalmente humano e que é realizado no decurso da História pelo homem graças à sua atividade produtiva. (FROMM, 1975, p. 42)

Assim sendo, o mundo objetivo e o processo de humanização se dão na práxis desenvolvida pelo homem nas suas relações (homens e natureza) ao constituírem sua história.

Fromm (1975) afirma que, ao debater a autorrealização humana, Marx chega aos conceitos de riqueza e pobreza em que ambos possuem um significado humano e, por isso, social. A perspectiva lançada é a da necessidade de outra pessoa. A riqueza está no fato da precisão de um complexo de manifestações humanas da vida e da efetivação da autorrealização. O homem rico é aquele que se adequa ao gênero humano, quando está diante da satisfação mais imediata: o intercâmbio com seus iguais. $\mathrm{O}$ homem pobre, em contraponto, vale-se das várias formas de posse oferecidas pela propriedade privada no sentido de "ter". Na ordem burguesa, o máximo da produção e do consumo são os objetivos inquestionáveis da sociedade. Sendo assim, uma contradição está posta: aquelas necessidades ligadas às questões de sobrevivência são secundarizadas, porque a criação de capital, através do trabalho alienado, é a necessidade prévia enquanto garantia dessas outras: "ter" dinheiro para "ter" o que comer, beber, vestir, onde morar. É nesse sentido que a "pauperização" humana se dá 
cada vez que os homens se distanciam da generalidade do ser social em sua plenitude de "ser" e se aproximam da "capitalização" do ser humano em decorrência do trabalho alienado.

Tem-se ainda que toda a concepção a respeito da autorrealização do homem só pode ser plenamente compreendida em ligação com sua concepção do trabalho. Concepção que agrega diferentes atribuições, mas que concorre para o entendimento do conceito de homem em Marx.

\begin{abstract}
Antes de mais nada, deve ser notado que trabalho e capital não eram, para Marx, meras categorias econômicas; eram categorias antropológicas, impregnadas de um juízo de valor oriundo de sua posição humanista. O capital, aquilo que é acumulado, representa o passado; o trabalho, por outro lado, é, ou devia ser quando livre, a expressão da vida. (...) O trabalho, para Marx, é uma atividade, não uma mercadoria. Marx inicialmente denominou a função do homem de "autoatividade" e não de trabalho, e falou na "abolição do trabalho" como objetivo do socialismo. Ulteriormente, quando estabeleceu a diferença entre trabalho livre e alienado, empregou a expressão "emancipação do trabalho". (FROMM, 1975, p. 46-47)
\end{abstract}

A concepção marxista de trabalho, de atividade humana produtiva, se apropria e é formulada nas noções de trabalho de Hegel e dos economistas políticos para a síntese do seguinte suposto: o trabalho constitui a essência do homem que é provada e é a mediação para a antropogênese ao regular e controlar as relações materiais entre os homens e a natureza. Não é só um meio para um fim, mas é, especialmente, um fim em si mesmo que corresponde ao processo de autocriação do ser social.

Ao atuar sobre o mundo exterior e modificando-o, ao mesmo tempo, o homem modifica sua própria natureza. "O trabalho humano transforma a realidade objetiva e faz dela, assim, a realidade humana, isto é, o resultado do trabalho humano" (SHAFF, 1967, p. 76; grifos do autor). Essa condição é, pois, o que caracteriza o trabalho em uma forma exclusivamente humana. O homem não é apenas um indivíduo ativo e produtivo, visto que age consciente e racionalmente (SHAFF, 1967). E o que distingue seu trabalho é o caráter teleológico. Como objetividade humana, ele possibilita a exteriorização da consciência mediada pela subjetivação do objeto produzido.

No ato do trabalho está a capacidade de objetivação do homem que se sustenta nas relações sociais dentro da esfera da vida material, entre os homens, e no metabolismo homens e natureza. Nessas trocas, o homem transforma-se a si mesmo, modificando as suas condições de existência e criando um mundo objetivo novo e, inclusive, o próprio homem (SCHAFF, 1967; FROMM, 1975).

Como elemento fundante do ser social na processualidade histórica, o ato de trabalho em suas contradições imediatas apresenta um duplo caráter de criação, mas também de 
sujeição, emancipação e alienação, humanização e degradação, libertação e escravização. Esses antagonismos permitem que Marx conteste as distintas maneiras de subordinação do trabalho ao capital ${ }^{13}$ e, concomitantemente, exija sentidos e significados outros do trabalho humano com vistas ao resgate daquilo que é próprio da natureza dos indivíduos e de outra lógica de sociabilidade que estabeleça a emancipação humana e social. O trabalho alienado é fonte da nocividade da propriedade privada e de seu modo de existência alheio ao homem (MARX, 1974). Por isso que "O tema central de Marx é a transformação do trabalho alienado e desprovido de significado em trabalho produtivo e livre, e não a melhor paga do trabalho alienado por um capitalismo privado ou por um capitalismo de Estado 'abstrato"” (FROMM, 1975, p. 49).

\subsubsection{A alienação: a expropriação do homem de si mesmo e a incompatibilidade ao gênero humano}

A partir do conceito marxista de homem produtivo e ativo, a alienação é a negação da "liberdade" humana, um condicionante de seu processo vital, que compreende e controla o mundo objetivo. A história do gênero humano coincide, imediatamente, e revela o desenvolvimento do fenômeno da alienação, pois os homens e suas objetivações estão passíveis à alienação como possibilidade no que se refere “(...) à relação do indivíduo humano com a sociedade e com os diversos produtos do homem, como homem social" (SCHAFF, 1967, p. 115; Grifo do autor). Assim, parte-se da atividade social do homem e de suas condições sociais.

\footnotetext{
A alienação (ou "alheamento") significa, para Marx, que o homem não se vivencia como agente ativo de seu controle sobre o mundo, mas que o mundo (a natureza, os outros, e ele mesmo) permanece alheio ou estranho a ele. Eles ficam acima e contra ele como objetos malgrado possam ser objetos por ele mesmo criados. Alienar-se é, em última análise, vivenciar o mundo e a si mesmo passivamente, receptivamente, como o sujeito separado do objeto. (FROMM, 1975, p. 50; Grifos do autor)
}

\footnotetext{
13 Marx (1999, p. 20) dá pistas desta subordinação quando destaca as diversas formas que o economista estabelece a unidade do capital e do trabalho: "l. ${ }^{\circ}$ ) o capital é trabalho acumulado; $2 .^{\circ}$ ) a determinação do capital no interior da produção, em parte a reprodução do capital com ganho, em parte o capital como matéria-prima (matéria do trabalho), em parte como instrumento que trabalha por si mesmo - a máquina é o capital posto imediatamente como idêntico ao trabalho — é o trabalho produtivo; $3 .^{\circ}$ ) o operário é um capital; $4 .^{\circ}$ ) o salário faz parte dos custos do capital; $5 .^{\circ}$ ) no que diz respeito ao operário, o trabalho é a reprodução do seu capital vital; $6^{\circ}$ ) no que diz respeito ao capitalista, é um fator de atividade do seu capital. Finalmente, $7 .^{\circ}$ ) o economista supõe a unidade originária de ambos como unidade do capitalista e do operário; esta é a paradisíaca situação primitiva" (Grifos do autor).
} 
Marx formula a essência da alienação: a automatização dos produtos do homem e das condições e relações pessoais dos indivíduos. Dessa forma, Schaff (1967) aborda as circunstâncias para que a alienação se materialize:

(...) quando os produtos do homem ganham uma existência autônoma, independe dele, e o homem não é capaz de combater, de maneira consciente, o funcionamento espontâneo dos seus próprios produtos, capazes de subordiná-los às suas leis e mesmo arriscar a sua vida. $\mathrm{O}$ domínio da realidade sobre o homem, da realidade que escapou ao seu domínio, rouba-lhe a sua humanidade, limita o desenvolvimento da sua personalidade, faz do homem um acréscimo para o mundo das coisas: da máquina, do aparelho burocrático do Estado, etc. A alienação, assim é, ao mesmo tempo, autoalienação do homem - do criador do mundo das coisas, perdido no mundo impessoal, não-humano, que o subordinou a si. Não são apenas os produtos do homem que se tornam estranhos ao homem, "se alienam", mas ele próprio se aliena, aliena-se como objeto do mundo dos objetos que o rodeia, começa a sentir-se por meio destes objetos. (Ibidem, p. 117)

Schaff (1967, p. 118) complementa esse trecho colocando o significado da afirmação de que a alienação é o domínio dos produtos humanos sobre o homem dizendo que:

Trata-se de um sinônimo para a espontaneidade do desenvolvimento social, quando a venda das mercadorias no mercado, a competição de armamento entre os Estados, atitudes nacionalistas, racismo, intolerância religiosa, etc., já não se subordinam à vontade e ao controle dos indivíduos humanos, quando subjugam o indivíduo, ou mesmo ameaçam a sua existência e, assim, limitam sua liberdade.

O trato dado por Marx à alienação se dá por vias da expropriação do homem de si mesmo e do gênero humano. Sendo assim, a negação de produtividade não deve denotar a ideia de homens improdutivos, que não produzem o "novo" no intercâmbio com seus semelhantes e com a natureza.

Para Marx, tal como para Hegel, o conceito de alienação baseia-se na distinção entre existência e essência, no fato de a existência do homem ficar alheada de sua essência, de na realidade ele não ser o que é potencialmente, ou, por outras palavras, de ele não ser o que deveria ser, e de ele dever ser aquilo que poderia ser. (FROMM, 1975, p. 53; Grifos do autor)

A produção do "novo" é feita, no entanto, por homens transformados em "coisas", uma vez que se exterioriza uma essência estranhada que não se realiza diante de uma existência "muda" e gera a desumanização do ser social, o qual renuncia a si mesmo e está indiferente à riqueza de suas próprias potencialidades e da sua omnilateralidade.

Embora Marx discuta a questão da exploração e subjugação do homem a suas obras espirituais e materiais, expondo ideias fundamentais acerca do tema da alienação religiosa na 
crítica da religião e da alienação sociopolítica e ideológica na crítica do Estado, sua atenção está ligada à base de toda alienação na sociedade capitalista: a econômica em que se tem a alienação da produção humana, quando da sua existência sob a forma de mercadorias. De tal modo, ele aborda as consequências da alienação no momento ontológico predominante do ser social em que este coloca suas forças criadoras em exercício e tem a experiência de si próprio em seu ato criador: a atividade produtiva, leia-se "trabalho".

O trabalho é alienado, porque o ato de trabalhar deixou de fazer parte da natureza do trabalhador que não se afirma em seu trabalho, mas se estranha e não se reconhece. É um trabalho que perde o status de potencialmente "humano" para assumir o de "estranhado".

$\mathrm{Na}$ ordem burguesa, na qual há uma intensificação da alienação do e através do trabalho, o trabalhador vive uma relação de oposição em três níveis de determinação:

1) em relação àquilo que ele produz: o produto do seu trabalho lhe aparece como algo "estranho" e a "criatura" passa a exercer um domínio sobre o "criador". "A relação do trabalhador com o produto do trabalho como objeto estranho e poderoso sobre ele. Esta relação é, ao mesmo tempo, a relação com o mundo exterior sensível, com os objetos da natureza como um mundo alheio que se lhe defronta hostilmente" (MARX, 2002-2003, p. 462). Torna-se inviável ainda a apropriação do trabalhador daquilo que ele produz: "A apropriação do objeto tanto aparece como estranhamento (Entfremdung) que, quanto mais objetos o trabalhador produz, tanto menos pode possuir e tanto mais fica sob o domínio do seu produto, do capital” (MARX, 2002-2003, p. 458).

2) em relação àquilo que ele faz - o ato da produção: estranha do homem sua própria função ativa, sua atividade vital e suas forças criadoras, distanciando do homem seu potencial transformador sob a realidade objetiva: A relação do trabalho com o ato da produção no interior do trabalho. Esta relação é
a relação do trabalhador com a sua própria atividade como uma [atividade] estranha
não pertencente a ele, a atividade como miséria, a força como impotência, a
procriação como castração. A energia espiritual e física própria do trabalhador, a
sua vida pessoal - pois o que é vida senão atividade - como uma atividade voltada
contra ele mesmo, independente dele, não pertencente a ele. O estranhamento-de-si
(Selbstentfremdung), tal qual acima o estranhamento da coisa. (MARX, 2002-2003,
p. 462; Grifos do autor) 
Para o trabalhador, o fato de ter que trabalhar vira causa de sofrimento e de angústia, um martírio, "foge-se do trabalho como de uma peste". Ele é infeliz quando trabalha e apenas sente a si mesmo fora do trabalho.

Primeiro, que o trabalho é externo (ausserlich) ao trabalhador, isto é, não pertence ao ser, que ele não se afirma, portanto, em seu trabalho, mas nega-se nele, que não se sente bem, mas infeliz, que não desenvolve nenhuma energia física e espiritual livre, mas mortifica sua Physis e arruína seu espírito. O trabalhador só se sente, por conseguinte e em primeiro lugar, junto a si [quando] e fora do trabalho e fora de si [quando] no trabalho. Está em casa quando não trabalha e, quando trabalha, não está em casa. O seu trabalho não é portanto voluntário, mas forçado, trabalho obrigatório. O trabalho não é, por isso, satisfação de uma carência (Bedurfnisses), mas somente um meio para satisfazer carências (Bedurfnisses) fora dele. [...] Chegase, por conseguinte, ao resultado de que o homem (o trabalhador) só se sente como [ser] livre e ativo em suas funções animais, comer, beber e procriar, quando muito ainda habitação, adornos, etc, e em suas funções humanas só [se sente] como animal. O animal se torna humano e o humano, animal. (MARX, 2002-2003, p. 461462)

3) em relação a si mesmo e aos outros seres humanos, diga-se de passagem, à espécie. Não se reconhece em seus iguais, porque os outros homens são para ele meios e não fins em si próprios. Nessa formação social, o trabalho, ao invés de ser uma atividade de autorrealização dos indivíduos, é apenas um meio para a sobrevivência.

O trabalho estranhado faz, por conseguinte: (...) do ser genérico do homem, tanto da natureza quanto da faculdade genérica espiritual dele, um ser estranho a ele, um meio da sua existência individual. Estranha do homem o seu próprio corpo, assim como a natureza fora dele, tal como a sua essência espiritual, a sua essência humana. (...) uma consequência imediata disto, do homem estar estranhado do produto do seu trabalho, de sua atividade vital e de seu ser genérico é o estranhamento do homem pelo [próprio] homem. Quando o homem está frente a si mesmo, defronta-se com ele o outro homem. O que é produto da relação do homem com o seu trabalho, produto de seu trabalho e consigo mesmo, vale como relação do homem com outro homem, como o trabalho e o objeto do trabalho de outro homem. (MARX, 2002-2003, p. 465; Grifos do autor)

Nesses casos, a divisão social do trabalho é o elemento que corrobora o ato de trabalhar e o de criar sensíveis como atos alienados e alheados da atividade humana, constituindo-se uma atividade genérica.

A divisão do trabalho é a expressão econômica do caráter social do trabalho no interior da alienação. Ou, posto que o trabalho não é senão uma expressão da atividade humana no interior da alienação, da exteriorização da vida como alienação da vida, assim também a divisão do trabalho nada mais é do que o pôr alienado, alheado da atividade humana enquanto atividade genérica real ou como atividade do homem enquanto ser genérico. (MARX, 1974, p. 24; grifos do autor) 
A divisão do trabalho impede a omnilateralidade do ser social em sua atividade humano-sensível. "Admite-se o empobrecimento e a dessencialização (Entwesung) da atividade individual por meio da divisão do trabalho" (MARX, 1974, p. 28). Enquanto emprego hábil das forças dos homens, ela capitaliza a diversidade de talentos, quando impõe a condição, mediada pela propriedade privada, da especialização do agir humano com vistas à produtividade e à riqueza monetária.

De acordo com Fromm (1975), o interesse de Marx, então, está voltado para a emancipação da alienação e a volta para si em sua realização na "libertação do homem de um gênero de trabalho que destrói sua individualidade, converte-o em coisa e torna-o escravo das coisas" (Ibidem, p. 54). O que se critica, na sociedade capitalista, é seu modo de produção, a destruição da individualidade e o modo como o capital se sobrepõe ao trabalho, fazendo do homem um meio de exploração e acumulação de capital, cujo governo é dominado por produtos feitos por suas próprias mãos e que lhes escapam o controle (FROMM, 1975).

\footnotetext{
Não é só o mundo das coisas que se torna superior ao homem, mas também as circunstâncias sociais e políticas por eles criadas se tornam seus senhores. (...) $\mathrm{O}$ homem alienado, que julga ter-se tornado o senhor da natureza, tornou-se escravo das coisas e das circunstâncias, o apêndice impotente de um mundo que é simultaneamente a expressão congelada de seus próprios poderes. (FROMM, 1975, p. 57; grifos do autor)
}

Dito de outra forma, a crítica repousa nessa impotência humana perante uma gama de fatores que o aprisiona como seu próprio refém. Desencadeia-se um tanto de implicações da base econômica como também da superestrutura envolta pela consciência social que converge para a produção e a reprodução dessa realidade.

A ordem burguesa organiza as relações de trabalho e a produção social da vida material de toda a humanidade em estados causais que promovem a alienação dos homens em diversos aspectos ligados à singularidade e ao gênero humano. "Para Marx, a alienação no processo de trabalho, do produto deste e das circunstâncias, está inseparavelmente ligada à alienação de si próprio, de seus semelhantes e da natureza" (FROMM, 1975, p. 57). São homens convertidos em qualidades de coisas em si. É uma sociedade de "mercadorias" em presença das demandas colocadas pelo capital: “(...) o trabalhador baixa (herabsinkt) à mercadoria e à mais miserável mercadoria (...)” (MARX, 2002-2003, p. 454). A mercadorização dos homens os degradam a apêndices da máquina produtiva ao vender sua força de trabalho por um salário. Este é seu preço. "Esse homem mercadoria só conhece um meio de relacionar-se com o mundo exterior: o de tê-lo e consumi-lo (usá-lo). Quanto mais 
alienado estiver, tanto mais a sensação de ter e usar constituirá sua relação com o mundo" (FROMM, 1975, p. 60).

Há aqui uma contraversão: os homens passam a servir a estrutura produtiva no atendimento das necessidades postas por ela e pelos proprietários dos meios de produção. E é, nesse sentido, que a propriedade privada é posta, destarte, no produto do trabalho alienado, o resultado necessário e a garantia para a reprodução do capital (FROMM, 1975).

Nesse contexto histórico em que resulta a alienação da essência do homem e de sua generalidade, a satisfação e a criação de novas necessidades alienadas passam a ser a força motriz. Da essência egoísta e avarenta emanam os anseios, as paixões, as necessidades de uma existência que é individual. Os esforços coletivos são aplicados como meio para essa essência particularizada na tensão entre o "burguês" e o "cidadão, manifesta na hipertrofia da singularidade: os meus desejos e os meus impulsos particulares sobrepujam o interesse dos demais, da coletividade. Assim, no mundo alienado pelo capitalismo, as necessidades reais ou potenciais não são expressões de poderes latentes do homem. Elas, as necessidades humanas que efetivam a essência do ser social, são distorcidas na rendição à propriedade privada, à riqueza econômica e ao dinheiro.

Enquanto desdobramento desse contexto de vinculação às necessidades do movimento interior da propriedade privada, Marx (1974), a partir da necessidade mais imediata do ser social, a do carecimento humano, situa o ser burguês como homem empobrecido, vez que "A pobreza é o laço passivo, que faz com que o homem sinta como carecimento a maior riqueza, o outro homem. A dominação em mim do ser objetivo, a explosão sensível de minha atividade essencial, é a paixão que, com isso, se converte aqui na atividade de meu ser" (Ibidem, p. 14; Grifos do autor).

E é nessa medida que o homem se torna cada vez mais pobre como homem através do trabalho alienado e, por conseguinte, da desumanização. Em sua adequação mais intensa à "capitalização da vida" e à instrumentalização das relações humanas, pois o indivíduo só existe para o outro como o outro só existe para ele na medida em que se tornam meio um para o outro, o homem fica mais inadequado à generalidade humana no empobrecimento de sua singularidade e, consequentemente, do gênero humano. A riqueza não está em "ser", mas em "ter".

E a oportunidade de "ter" permanece no cerne do dinheiro, pois por ele me torno hábil a "ser" e a "possuir". "Aquilo que mediante o dinheiro é para mim, o que posso pagar, isto é, o que o dinheiro pode comprar, isso sou eu, o possuidor do próprio dinheiro. Minha força é tão grande como a força do dinheiro. As qualidades do dinheiro - qualidades e forças 
essenciais - são minhas, de seu possuidor” (MARX, 1974, p. 30; Grifos do autor). Enquanto proprietário privado, o dinheiro proporciona ao homem qualidades, forças essenciais inexistentes em sua individualidade. O dinheiro é, pois, a capacidade alienada do gênero humano. Aquilo que eu não posso como homem, o dinheiro pode como conversor de representações e imperfeições em forças e poder efetivos. "É a irmanação das impossibilidades; obriga aquilo que se contradiz a beijar-se" (MARX, 1974, p. 32). Tudo é suscetível a ser possuído na determinação dos laços sociais e da relação com o mundo das coisas.

\begin{abstract}
$\mathrm{Na}$ medida em que é o dinheiro, que aparece como meio, o verdadeiro poder e o único fim; na medida em que o meio em geral, que me faz ser, que faz meu o ser objetivo estranho, é um fim em si mesmo [...] é o que se pode ver no fato de como a propriedade da terra (ali onde a terra é a fonte da vida), o cavalo e a espada (ali onde eles são o verdadeiro meio de vida) são reconhecidos também como as verdadeiras forças políticas da vida. (MARX, 1974, p. 21-22; Grifos do autor)
\end{abstract}

O carecimento do dinheiro é a verdadeira necessidade e a exploração de carências que se põem nesses laços, convertendo o dinheiro em seu elemento de vida. "O gozo é subordinado ao capital e o indivíduo que goza é subordinado àquele que capitaliza (...)" (MARX, 1974, p. 23). Trata-se aqui da condição moralizante de corruptibilidade imposta ao ser social.

\begin{abstract}
A alienação aparece tanto no fato de que meu meio de vida é de outro, que meu desejo é a posse inacessível de outro, como no fato de que cada coisa é outra que ela mesma, que minha atividade é outra coisa, e que, finalmente (e isto é válido também para o capitalista), domina em geral o poder desumano. (MARX, 1974, p. 22; Grifos do autor)
\end{abstract}

Mediante o domínio do dinheiro, as afirmações ontológicas metamorfoseiam-se em manifestações efetivas da existência alienada humana. Por isso, a luta de Marx é pelo homem. Não só pelos trabalhadores das classes desfavorecidas, mas, também, pelos capitalistas, que, segundo Fromm (1975), ao apontar uma correção nas colocações de Marx, também estão expostos a diferentes mecanismos de se alienar. Procura-se, portanto,

(...) criar uma forma de produção e uma organização da sociedade onde o homem
possa superar a alienação de seu produto, de seu trabalho, de seu semelhante, de si
mesmo e da natureza; na qual ele possa regressar a si mesmo e apreender o mundo
com suas próprias forças, tornando-se, destarte, unido ao mundo. (FROMM, 1975,
p. 62)

Um resgaste, pois, do constante vir-a-ser humano em suas potencialidades intrínsecas e reais da essência do homem que se formou ao longo da história. Condições de existência nas 
quais os homens tenham oportunidades de efetivar o seu ser em potencial e, tão logo, se enriquecerem em uma sociabilidade que atenda à necessidade humana mais imediata: ser humano ao lado de outros que também assim o são: "Eu sou porque nós somos!" 


\title{
CAPÍTULO II - LUKÁCS E OS PRINCÍPIOS ONTOLÓGICOS FUNDAMENTAIS DE MARX
}

O propósito deste capítulo é trazer as sínteses lukacsianas acerca dos princípios ontológicos fundamentais de Marx como seus primeiros passos que culminam na ontologia do ser social em Lukács $\left(1978^{14} ; 2012\right)$. O modo como Lukács vai conectando essas sínteses reflete seu objetivo de dar luz às mais importantes dentre as determinações gerais da ontologia marxiana do ser social, dando-lhes o devido valor de seus significados ontológicos.

A teoria social de Marx está ligada a um projeto revolucionário que endossa teorias e práticas sociais também revolucionárias, existindo uma correlação dialética entre suas elaborações teóricas e metodológicas. Sendo assim, são dois os supostos que regulam esse objetivo.

O primeiro suposto parte da ideia de que, dando um enfoque científico ao seu objeto de pesquisa, a sociedade burguesa, Marx reproduz idealmente o movimento do real de determinada formação social. Ao fazer isso, ele passa a compreender a existência real e efetiva desse objeto. E uma vez que no exercício da prática científica não permanece um pretenso juízo de neutralidade, como destaca Lukács (2012, p. 294), pela indicação de Hobbes sobre a presença do "agir interesseiro", tem-se que a ciência pode e está submetida a uma organização social baseada em classes. Ela não deve ser considerada um complexo neutro em relação aos antagonismos, conflitos e mediações sociais. Marx deixa isso muito claro, quando traz como premissa o fato de conhecer para transformar. Uma transformação que perpassa a superação da ordem social do capital.

O segundo acena para o que Paulo Netto (2011, p. 55) alega:

\begin{abstract}
A indissociável conexão que mencionamos impede uma abordagem que, na obra de Marx, autonomize o método em face da teoria: não é possível, senão ao preço de uma adulteração do pensamento marxiano, analisar o método sem a necessária referência teórica e, igualmente, a teoria social de Marx torna-se ininteligível sem a consideração de seu método. (Grifos do autor)
\end{abstract}

A fim de se apreender os fundamentos do pensamento marxiano, é preciso repousar um olhar crítico sobre sua totalidade. Totalidade esta explicada por Paulo Netto (2011) pelos meandros históricos da trajetória de Marx: nos anos de 1840, ele articula teorias por meio do trato feito ao material histórico-social aprendido por ele - o tripé filosofia alemã, economia

14 Traduzido por Carlos Nelson Coutinho, o conteúdo compendiado neste texto sintetizando o trabalho ontológico de Lukács foi escrito em 1968 como base para uma conferência do Congresso Filosófico Mundial, realizado em Viena, no qual Lukács não pôde estar presente. 
política inglesa e socialismo francês, e elas objetam propostas metodológicas. Os anos de 1850, guiados pelo que foi alcançado metodologicamente falando, instigam progressos teóricos e estes, novas exigências metodológicas.

A produção da "Introdução" de $57^{15}$ assinala a evolução marxiana através do trabalho com os maiores pensadores da cultura ocidental que o precedem. Nessa obra, Marx se desloca da crítica da filosofia para a crítica da economia política. Essa evolução advém, ao mesmo tempo, de sua adequação às demandas metodológicas inerentes ao objeto, ao passo que a anatomia da sociedade burguesa deveria ser procurada na economia política, conclusão que serviu de linha condutiva para seus estudos. Uma nova relação com o objeto é firmada nos Elementos fundamentais para a crítica da economia política e Rascunhos. 1857-1858. Isso fez com que houvesse uma maior expurgação na estruturação do método e tanto o tratamento teórico quanto a formulação metodológica aparecem explicitados n 'O capital.

A "Introdução" de 57 é o indicativo de 15 anos de estudos durante os quais lidou com uma enorme quantidade de literatura socioeconômica e organizou as bases de sua própria teoria econômica. Esses anos colaboraram para a consignação dos elementos centrais do método de Marx, mostrando seu amadurecimento em função das sucessivas aproximações ao seu objeto. Sua importância reside basicamente na formulação, no emprego e na rigorosidade das categorias do método dialético do movimento histórico convertido em ferramenta metodológica do estudo da economia política. Nela se encontram as fundamentações analíticas do percurso investigativo que possibilitaram a consubstanciação d' $O$ capital como apresentação dos resultados conquistados.

O que se localiza nessa "Introdução" é mais tarde recuperado por Marx n' $O$ Capital, de modo mais preciso e coerente. Esta última é a obra marxiana derradeira, que sintetiza sistemática e categoricamente a dinâmica e a estrutura da organização capitalista e a fundação da teoria social de Marx (PAULO NETTO, 2011).

Certo é que a ocorrência apenas desse texto produzido relativo à sistematização de sua concepção teórico-metodológica revela o quão preocupado Marx não estava em observar

15 Este texto está dividido em quatro partes: 1. Produção; 2. As Relações Gerais entre a Produção e a Distribuição, a Troca e o Consumo; 3. O Método da Economia Política; 4. Produção. Meios (Forças) de Produção e Relações de Produção. Relações de Produção e Relações de Circulação. Embora se reconheça a rica discussão que Marx faz para evidenciar categorias básicas do materialismo histórico-dialético, que darão sustentação metodológica para os seus estudos de economia política, para a finalidade desta pesquisa, o tópico 3 é o mais abordado. 
a fundo conteúdos meramente epistemológicos ou criar um método para "conhecer" e "validar" a realidade existente com uma simples aplicabilidade ${ }^{16}$.

(...) para Marx, o método não é um conjunto de regras formais que se "aplicam" a um objeto que foi recortado para uma investigação determinada nem, menos ainda, um conjunto de regras que o sujeito que pesquisa escolhe, conforme sua vontade, para "enquadrar" o seu objeto de investigação. (PAULO NETTO, 2011, p. 52)

O interesse não era por um abstrato e especulativo "como conhecer", mas sobre "como conhecer um objeto real e determinado". Os esforços, na verdade, não eram por uma esquemática ciência da lógica, pelo contrário, o empenho estava voltado para a lógica de um objeto em particular (PAULO NETTO, 2011).

\begin{abstract}
Mesmo que Marx não nos tenha deixado uma lógica [...], ele nos deixou porém a lógica de $O$ capital [...]. Em $O$ capital, aplicam-se a uma mesma ciência a lógica, a dialética, a teoria do conhecimento (não seriam necessárias três palavras: são todas a mesma coisa) do materialismo, que recolheu de Hegel tudo o que nele há de precioso o desenvolveu ulteriormente. (LÊNIN, 1932, p. 249 apud LUKÁCS, 2012, p. 300; Grifo do autor)
\end{abstract}

O capital é, por assim dizer, a etapa na qual Marx conclui sua pesquisa e a síntese cumulativa do que ele entende por conceptualização da produção do conhecimento científico. Ele institui noções como a relação sujeito/objeto, o processo de conhecimento, a instância de verificação da verdade de uma teoria na prática social e histórica, entre outras. Esse livro é o produto final da pesquisa na qual ele utiliza o método de exposição ${ }^{17}$ para demonstrar como tornou seu objeto de estudo menos indeterminado, descobrindo suas categorias e determinações centrais fundadas em termos tanto ontológicos quanto filosóficos.

O núcleo metodológico da doutrina marxiana é inverso ao conceito de unidade, determinado pela ideia de um sistema, sobretudo o hegeliano, de ontologia, lógica e teoria do conhecimento. Pela orientação do seu pensamento ser de natureza ontológica e não epistemológica, a busca girava em torno de se construir reflexões mais profundas acerca dos caracteres ontológicos do ser social, salientando que as determinações ontológicas devem estar essencialmente na base de qualquer ciência e que é o método da economia política a

\footnotetext{
${ }^{16}$ Devido à subordinação da preocupação epistemológica à impostação ontológica, de acordo com Húngaro (2008), as principais aquisições teórico-metodológicas discutidas por Marx encontram-se na Ideologia Alemã (1845/46), na Miséria da Filosofia (1847), na Introdução de 1857 e no prefácio e posfácio à segunda edição d'O Capital.

${ }^{17}$ Existe uma distinção entre o método de pesquisa e o método de exposição em Marx. Eles têm pontos de partida opostos: "na investigação, o pesquisador parte de perguntas; na exposição, ele já parte dos resultados que obteve na investigação" (PAULO NETTO, 2011, p. 27).
} 
ilustração do seu método de pesquisa. Dessa forma, Marx inova nas concepções de cientificidade e de ontologia (LUKÁCS, 2012).

Lukács (2012) faz uma apresentação histórico-crítica da compreensão teóricometodológica marxiana. Assim ele perpassa questões pontuais da perspectiva de pesquisador ${ }^{18}$ que Marx vai assumindo ao se comportar como um sujeito que pesquisa inserido no objeto, estimula a ampliação das suas produções espirituais e aprimora seu estilo de fazer ciência. Sua distinção como sujeito pesquisador é fruto do seu enriquecimento contínuo no processo investigativo pela incorporação de parte da generalidade humana. Esta o condiciona a uma sensibilidade cada vez mais inerente à especificidade do ser social e das problemáticas infligidas na processualidade histórica. Isso acontece nos diferentes momentos de Marx de apreciação da realidade concreta, estudos, autoesclarecimentos, sistematizações e produções.

Ao desenvolver a atividade humano-sensível da pesquisa sempre preservando essas características, os indicadores são de que Marx vai caminhando para a explicitação daquilo que ele põe como traços da aproximação a adequação ao gênero humano. Ou seja, sua atuação de pesquisador reflete a forma rica de ser humano em que ele estava se transformando. Assim, o ponto de partida são os aspectos próprios do ser social na tensão entre a ontologia e a cientificidade, quando da problematização de uma indispensável investigação dos marcos ontológicos na construção das objetividades científicas e nas disposições da reprodução da realidade exterior na consciência como forma de conhecimento.

É pertinente falar como essa tensão entre ontologia e cientificidade é de fundamental relevância diante da força material que a cientificidade tem na determinação dos atos sociais no que Lukács, após Hartmann, denomina de intentio recta e intentio obliqua, e para o entendimento da crítica feita por Marx ao paradigma de cientificidade da ciência moderna.

O trecho: "A necessidade, essencial do trabalho, de captura do real pela consciência, de modo que possa transformar com sucesso a realidade segundo uma finalidade previamente idealizada, é o fundamento ontológico de um impulso ao conhecimento do real" (LESSA, 2012, p. 48) conceitua o que Lukács chama de intentio recta. A princípio, um pré-requisito do trabalho: "e tão somente através de um conhecimento correto, através do trabalho, é que

\footnotetext{
${ }^{18}$ Paulo Netto (2011), segundo o que Marx coloca, evidencia como o papel do pesquisador é preponderante na pesquisa. Esse papel é altamente ativo no sentido preciso de conduzir a investigação na superação do que é aparente ou imediatamente dado. Deve-se apreender o objeto enquanto processo vislumbrando sua essência, estrutura e dinâmica. Para tanto, é necessário ser um pesquisador enriquecido para mobilizar a maior quantidade possível de conhecimentos, criticando-os e revisando-os com criatividade e imaginação até mesmo para estabelecer as mediações pertinentes. "Marx, aliás, caracteriza de modo breve e conciso tal processo: na investigação, o sujeito 'tem de apoderar-se da matéria, em seus pormenores, de analisar suas diferentes formas de desenvolvimento e de perquirir a conexão que há entre elas"” (MARX, 1968, p. 16 apud PAULO NETTO, 2011, p. 25).
} 
podem ser postos em movimento, por ser convertidos (os objetos naturais) em coisas úteis. Essa conversão em coisas úteis, porém, é um processo teleológico (...)” (LUKÁCS, 2012, p. 287). O êxito desse processo é, então, comentado no trecho que diz que: "Somente sobre a base de um conhecimento ao menos imediatamente correto das propriedades das coisas e dos processos é que o pôr teleológico do trabalho pode cumprir sua função transformadora" (LUKÁCS, 2012, p. 288). Contudo, por causa do aparecimento de sociabilidades mais complexas, houve um desdobramento para além do trabalho. A exigência de um efetivo conhecimento $^{19}$ do setor da realidade que se pretende transformar conforme finalidades socialmente postas em determinado processo de objetivação está intrínseca a inúmeras e variadas formas de atividade humano-social.

A origem da ciência está na assimilação de conhecimentos adequados para fins de acordo com a apreensão do ser-precisamente-assim existente. $O$ desenvolvimento da sociabilidade, ao dar possibilidades, também cobrou que a ciência se tornasse um complexo social específico, altamente especializado e sofisticado, estabelecendo mediações que não mais se limitam à transformação da natureza, mas progridem sobre outros domínios do mundo dos homens (LESSA, 2012).

Sobre a intentio obliqua, Lessa (2012, p. 59) afirma:

\begin{abstract}
Esse impulso à constituição de "Ontologias fictícias", e que tem seu fundamento ontológico último no trabalho (...). Fazendo uma contraposição com a intentio recta, a intentio obliqua se constitui enquanto uma interpretação globalizante do existente a partir de uma antropomorfização do ser. A teologia, categoria puramente social e presente apenas nos atos singulares dos indivíduos historicamente determinados, é estendida a toda a natureza, convertendo-se em categoria que confere sentido à ordem universal. A teleologia, de humana e restrita ao ser social, torna-se divina, universal. Os poderes humanos são potencializados e absolutizados em poderes divinos, o acaso e o desconhecido são explicados pela vontade - esta, muitas vezes inexplicável - dos deuses.
\end{abstract}

A intentio obliqua parte da associação entre o conhecimento do real e um conjunto maior de conhecimentos, concepções, visão de mundo etc, falsos que acaba interpretando a vida de maneira a lhe dar um sentido genérico, universal e desempenhando papéis capitais no desenvolvimento da generalidade humana, ao se relacionar com a espontânea teologia da vida cotidiana. As "ontologias fictícias" exerceram mediações históricas concretas e ainda o fazem: “(...) foram mediações importantes por meio das quais os indivíduos puderam referir a si próprios as demandas e as exigências postas pelo desenvolvimento do gênero humano

\footnotetext{
${ }^{19}$ Lessa (2012, p. 50) destaca, por meio de Lukács, que o conhecimento preciso para a transformação do real poderá atuar mais satisfatoriamente na sua função social quanto mais desantropomorfizado for, longe da subjetividade individual, do emotivo e do instintivo.
} 
enquanto tal" (LESSA, 2012, p. 58). Porém, essa antropomorfização operante no conhecimento do real, dando forma humana ao ser dos seres, pode gerar enormes obstáculos ao devir-humano dos homens, o que pode ser exemplificado na ontologia defendida na postulação do ser social burguês. Por essas e por outras questões, há de se questionar a qualidade científica que esse ou aquele conhecimento pode adquirir.

Dito isso, para se elucidar minimamente os alicerces metodológicos da ontologia marxiana, Lukács (2012) faz um retorno a fim de apontar as evoluções resultantes dos escritos filosóficos juvenis de Marx. É nesse período que se define o início de sua caminhada nos anos de 1840 com a arrancada nos Manuscritos econômico-filosóficos de 1844 (PAULO NETTO, 2011), oportunidade em que aparecem os pressupostos elementares da ontologia marxiana.

De modo análogo ao que se passa com a inexistência da criação a rigor de um tratado metodológico de pesquisa, Marx não discute separadamente os problemas ontológicos do ser social. Isso é central para se pensar o que envolve os êxitos de Marx no que permeia um fazer científico estabelecido numa ontologia materialista e histórica.

Há, portanto, um paradoxo no entendimento da essência e estrutura da ontologia marxiana. Os enunciados concretos de Marx se referem a um tipo de ser, sendo provenientes de afirmações puramente ontológicas. No entanto, a textualidade de Marx não possui uma exclusividade para as problemáticas de cunho ontológico e nem para determinação estrita delas no seu pensamento em possíveis relações com a teoria do conhecimento, a lógica, etc. Tal fato sofre influências da filosofia hegeliana em razão da colocação de contornos de unificação e dialética entre esses elementos e da ambivalência, encontrada por Engels e Lênin, na identificação de tendências materialistas que atuam dentro do idealismo objetivo (LUKÁCS, 2012).

Como destacado anteriormente, é nos alcances da filosofia na batalha contra o idealismo que Marx desenvolve decisivamente o ponto de vista materialista, a partir do qual orienta sua concepção ontológica, analisando criticamente o materialismo de Feuerbach de maneira a superá-lo. Na contestação das fragilidades desse materialismo vulgar, as questões ontológicas do ser social fixam suas raízes em linhas materialistas mais legítimas, visto que a generalidade humana e o problema da natureza aparecem sob uma luz ontológica inteiramente diferente.

Outras sinalizações do desenvolvimento de Marx, na condição de economista e materialista, são postas por Lukács (2012), como, por exemplo, a realidade social como critério último para validar a caracterização do ser ou não-ser social de uma manifestação fenomênica, e a materialidade que determinadas formas de consciências têm na realidade por 
sua função prático-social, mesmo diante do seu falseamento ou da sua veracidade no âmbito ontológico geral.

Entretanto, a descoberta mais significativa diz sobre “(...) aquele direcionamento no rumo da concretização cada vez maior das formações, das conexões etc do ser social, que, justamente em sentido filosófico, alcançará seu ponto de inflexão nos seus estudos econômicos" (LUKÁCS, 2012, p. 284). Ela é expressão da grande "sacada" de Marx que se torna determinante para a compreensão da especificidade do ser social: as categorias econômicas se realizam enquanto categorias da produção e da reprodução material da vida humana. A economia passa a ser o cerne da ontologia marxiana, possibilitando uma demonstração ontológica do ser social sobre bases objetivas materiais - a teoria geral do ser e sua especificação em face da sociedade. Lukács (2012) afirma que o debruçar de Marx pela economia é fruto do enriquecimento filosófico que o conduziu ao materialismo.

No momento em que Marx faz da produção e da reprodução da vida humana o problema central, surgem, tanto no próprio ser humano como em todos os seus objetos, relações, vínculos etc. como dupla determinação de uma insuperável base natural e de uma ininterrupta transformação social dessa base. (LUKÁCS, 2012, p. 285)

É a evidência da centralidade da categoria trabalho, eterna mediação necessária entre o ser social e a natureza, a garantia do carecimento material da espécie humana. Essa atividade constitui a dialética da dupla transformação operante na processualidade social: ao intervir na realidade objetiva, o homem também se transforma. No processo de trabalho, o significado ontológico da teleologia assume sua determinação na caracterização da esfera do ser social. A razão ontológica fundamental é a de que a causalidade está posta em movimento por decisões teleológicas alternativas. Portanto, o pôr teleológico (ou a posição teleológica) no trabalho emerge como o salto ontológico para além do ser genuinamente natural: reprodução do novo.

Lessa (2012) acrescenta que a reprodução do novo pelo ser social tem sua presença desdobrada no interior de relações objetivas e determinações que são preexistentes. Elas estão difundidas nas vinculações do indivíduo com a humanidade, mediadas pela consciência e pela sociedade, e são permeadas pelo fator causalidade. A interação teologia e causalidade lembra que, para Lukács, o produto do processo de trabalho provoca alterações na realidade em curso, desenrolando nexos causais que, na sua totalidade e na prévia-ideação, não podem ser conhecidos, visto que não ocorreram. Essa relação dialética entre teleologia e causalidade se consiste na essência do trabalho, uma vez que a teleologia se estabelece como "categoria ontologicamente objetiva, pertencente à essência do mundo dos homens" (LESSA, 2012, p. 
45). Ou seja, são as intenções interventivas dos homens previamente concebidas que constituem uma atmosfera humana no mundo objetivo.

\begin{abstract}
Ao contrário da causalidade, que representa a lei espontânea na qual todos os movimentos de todas as formas de ser encontram a sua expressão geral, a teleologia é um modo de pôr - posição sempre realizada por uma consciência - que, embora guiando-as em determinada direção, pode movimentar apenas séries causais. (LUKÁCS, 1978, p. 6; Grifos meus)
\end{abstract}

A implicação interativa da teleologia com a causalidade encerra determinado desenvolvimento através de consequências e resultados inesperados dos quais emanam novas necessidades e, assim, possibilidades do atendimento dessas necessidades como um ciclo vicioso.

Lukács (1978) clarifica isso sugerindo que o ser social é um ser que produz respostas. Então, a atividade laborativa é realizada como resposta, oferecendo potencialmente recursos solucionadores do carecimento que a provoca.

\footnotetext{
(...) o homem torna-se um ser que dá respostas precisamente na medida em que paralelamente ao desenvolvimento social e em proporção crescente - ele generaliza, transformando em perguntas seus próprios carecimentos e suas possibilidades de satisfazê-los; e quando, em sua resposta ao carecimento que a provoca, funda e enriquece a própria atividade com tais mediações, frequentemente bastante articuladas. (Ibidem, p. 5)
}

Por intermédio da consciência, a reprodução do novo parte da análise de uma situação concreta e da escolha da resposta ao mundo objetivo entre as inúmeras alternativas possíveis que são colocadas no processo de acumulação. O ato de responder é, pois, o elemento ontologicamente elementar no complexo dinâmico "resposta-pergunta", mesmo que ambas sejam produtos contíguos da consciência que orienta a atividade. Enquanto agente propulsor do processo de reprodução a nível de individualidade e sociabilidade, somente o carecimento material condiciona efetivamente o complexo de trabalho e todas as mediações existentes ontologicamente que agem em função da sua satisfação. Esta satisfação só pode ocorrer com o auxílio de uma cadeia de mediações que, permanentemente, transformam a natureza ao redor da sociedade e também os homens atuantes nela em suas relações recíprocas. Isso se deve ao fato de que tais mediações se revolvem como forças, relações, qualidades etc da natureza e fazem com que os homens libertem e dominem essas forças, pondo em movimento evolutivo suas próprias disposições. Assim sendo, tem-se com o trabalho, no plano ontológico, a possibilidade de desenvolvimento dos homens que trabalham, pois é nesse ato que se explicita 
a particularidade do ser social se modificando no molde da nova forma de ser em sua totalidade (LUKÁCS, 1978).

Recuperando acordado em Lukács (1978, p. 6), “O trabalho é formado por posições teleológicas que, em cada oportunidade, põem em funcionamento séries causais ${ }^{20 " . ~ E s s a ~}$ afirmação coloca uma faceta dupla que precisa ser compreendida. A existência real da maior parte das atividades concretizadas em uma sociedade desenvolvida socialmente é cometida de conexões causais que não podem ser de caráter teleológico. A contrariedade está no sentido de que o conjunto dessas atividades coloca a totalidade em movimento e que, seguramente, tem procedência teleológica. Toda práxis social tem, em si, essa contrariedade de se tomar como modelo o trabalho em relação ao agir humano. Os atos sociais surgem de uma opção entre alternativas sobre posições teleológicas vindouras. Desse modo, a necessidade social só pode se realizar diante da pressão feita sobre os indivíduos singulares com o intuito de que suas decisões tenham uma determinada orientação. Marx se remete a essa conjuntura afirmando que os homens são expostos a circunstâncias em que devem agir de tal modo com chances de se arruinarem, tendo em vista que, efetivando por si as próprias ações, podem o fazer contra sua opinião.

Nesse contexto de implicações inevitáveis a qual os homens que vivem em meio a outros estão submetidos, há a possiblidade de ligar todos os problemas reais ao complexo da liberdade. Lukács (1978) se restringe a debater as categorias "valor" e "dever-ser" no âmbito do trabalho estrito. Na natureza, nenhuma dessas categorias são encontradas, tanto na natureza inorgânica quanto na orgânica, dadas as suas especificações. Não existe uma clara relação com valores, mesmo que nesta última haja uma oposição envolvendo êxito ou fracasso, mas nada que supere os limites de um mero ser-de-outro-modo. A situação é distinta quando se trata do trabalho perante a estimativa lançada sobre o valor de uso do produto.

O conhecimento em geral distingue bastante nitidamente entre o ser-em-si, objetivamente existente, dos objetos, por um lado, e, por outro, o ser-para-nós, meramente pensado, que tais objetos adquirem no processo cognoscitivo. No trabalho, ao contrário, o ser-para-nós do produto torna-se uma sua propriedade objetiva realmente existente: e trata-se precisamente daquela propriedade em virtude da qual o produto, se posto e realizado corretamente, pode desempenhar suas funções sociais. Assim, portanto, o produto do trabalho tem um valor (no caso de fracasso, é carente de valor, é um desvalor). (LUKÁCS, 1978, p. 7-8)

\footnotetext{
20 Acerca do modo como as posições teleológicas operam no ser social, Lukács (1978, p. 6-7) relata como preconceitos ontológicos foram criados milenarmente em função da ignorância de filosofias anteriores: “( (..) eram obrigadas a inventar, por um lado, um sujeito transcendente, e, por outro, uma natureza especial onde as correlações atuavam de modo teleológico, com a finalidade de atribuir à natureza e à sociedade tendências de desenvolvimento de tipo teleológico".
} 
Assim, a colocação de valores apenas pode surgir da objetivação real do ser-para-nós em função do desempenho do produto nos limites da sociabilidade. E não é possível negar o significado da gênese ontológica dos valores pelo fato de eles assumirem contornos mais espirituais em estratos mais altos da sociedade. Em relação ao dever-ser, isso sucede de forma parecida.

\begin{abstract}
O conteúdo do dever-ser é um comportamento do homem determinado por finalidades sociais (e não por inclinações simplesmente naturais ou espontaneamente humanas). Ora, essencial ao trabalho é que nele não apenas todos os movimentos, mas também os homens que o realizam, devem ser dirigidos por finalidades determinadas previamente. Portanto, todo movimento é submetido a um dever-ser. Também aqui não surge nada de novo, no que se refere aos elementos ontologicamente importantes, quando essa estrutura dinâmica se transfere para campos de ação puramente espirituais. (LUKÁCS, 1978, p. 8; Grifos meus)
\end{abstract}

Pelo contrário, os elos da cadeia ontológica são claramente realçados. Nos métodos gnosiológico-lógicos, o percurso que conduz as formas mais elevadas às mais espirituais é tido como obscuro ou, inclusive, como oposto (LUKÁCS, 1978).

Uma situação inegável perpassa o processo global do trabalho. O sujeito realiza no trabalho uma posição teleológica de maneira consciente de modo que não pode visualizar todos os condicionamentos da própria atividade e tampouco suas consequências. Em várias ocasiões, sob pena de uma possível ruína, ele age tendo noção de que não conhece nem minimamente uma parte das circunstâncias. Mas, na maioria das vezes, ele sabe que seu domínio é restrito em relação aos elementos circunstantes e que, mesmo diante dessas condições, ele é capaz de executar o trabalho para satisfazer o carecimento (LUKÁCS, 1978).

Conforme Lukács (1978), uma das consequências geradas por tais situações se deve, em primeiro lugar, à dialética interna do permanente aperfeiçoamento do trabalho, pois, durante a realização do trabalho, seus resultados são notados estabelecendo uma faixa de crescimento das determinações que se tornam cognoscíveis e, consequentemente, o trabalho gradativamente fica mais variado, abarcando outros setores maiores em dimensão e magnitude. Uma vez que esse processo de aperfeiçoamento não pode negar a incognoscibilidade do conjunto de situações, é criada, a partir dele, uma mistificação colocando-o como fonte de determinadas formas ideológicas como uma realidade transcendente, a fé, a magia, a criação divina, coisas produzidas teleologicamente por um criador onisciente.

A condição do trabalho como um ato de pôr teleológico sugere o pressuposto no qual, embora insuficiente, haja a exigência de um conhecimento concreto de determinadas 
finalidades e meios. O seu aprimoramento, uma de suas características ontológicas, constitui o momento no qual produções sociais de estado mais elevado ganham vida. "Talvez a mais importante dessas diferenciações seja a crescente autonomização das atividades preparatórias, ou seja, a separação - sempre relativa - que, no próprio trabalho concreto, tem lugar entre o conhecimento, por um lado, e, por outro, as finalidades e os meios" (LUKÁCS, 1978, p. 10). Isso significa que diferentes ciências têm suas origens nesse estágio preparatório do trabalho e a ampliação de seus alcances estenderam-nas para campos do conhecimento atomizados, o que não elimina a ligação com sua funcionalidade original. Assim, a universalidade e a perfeição do trabalho advêm proporcionalmente do fato de as ciências se tornarem mais universais e autônomas da mesma maneira em que a reflexibilidade do conhecimento, obtido sobre as finalidades e os meios de efetivação do trabalho, cresce de acordo com o desenvolvimento e a intensificação do complexo científico.

Lukács (1978) indica uma relativa forma aperfeiçoada de divisão do trabalho por essa diferenciação no âmbito de sua fase preparatória, sendo que essa divisão é a implicação mais elementar do próprio desenvolvimento do ato de trabalho. Esse fenômeno já é perceptível mesmo antes da explicitação plena e intensiva do trabalho.

\begin{abstract}
Digna de nota, para nós, é aqui a manifestação de uma nova forma de posição teleológica; ou seja, aqui não se trata de elaborar um fragmento da natureza de acordo com finalidades humanas, mas ao contrário um homem (ou vários homens) é induzido a realizar algumas posições teleológicas segundo um modo prédeterminado. Já que um determinado trabalho (por mais que possa ser diferenciada a divisão do trabalho que o caracteriza) pode ter apenas uma única finalidade principal unitária, torna-se necessário encontrar meios que garantam essa unitariedade finalística na preparação e na execução do trabalho. Por isso, essas novas posições teleológicas devem entrar em ação no mesmo momento em que surge a divisão do trabalho; e continuam a ser, mesmo posteriormente, um meio indispensável em todo trabalho que se funda sobre a divisão do trabalho. (Ibidem, p. 10)
\end{abstract}

O que Lukács (1978) tenta dizer se refere à necessidade da realização de posições teleológicas devidamente adequadas ao perfil de determinada finalidade única a qual o trabalho precisa atingir. Dentro da questão da diferenciação social de maior complexidade e da gênese de classes sociais com interesses contrários, esse tipo de posição teleológica é a base "espiritual-estruturante" do que a concepção marxista entende por ideologia. Com outras palavras, é como se as manifestações ideológicas gerassem formas por meio das quais os homens pudessem compreender os conflitos suscitados pelas contradições postas pelos modos de produção mais desenvolvidos e acabassem se inserido na luta de classes.

Esses conflitos perpassam cada vez mais profundamente a totalidade social. Nesse sentido, Lukács (1978) vem falar que existe um mesmo eixo estrutural, tanto para a questão 
de um necessário saber real para o êxito no intercâmbio do meio social com a natureza, como também na requisição de um saber específico acerca do que os homens são feitos, das suas recíprocas relações individuais e sociais para que haja a viabilização das posições teleológicas aspiradas. “(...) os conhecimentos que influenciam o intercâmbio orgânico com a natureza são muito mais facilmente desvinculáveis das posições teleológicas que condicionaram o seu aparecimento do que os conhecimentos dirigidos no sentido de influenciar os homens e os grupos humanos" (LUKÁCS, 1978, p. 11). Dois aspectos podem ser percebidos nessa afirmação acerca da fundamentalidade dos conhecimentos de cunho ontológico do ser social. Esses conhecimentos são essenciais na determinação e no condicionamento das ações humanas, e eles não podem ser suprimidos da formação de consciências, sobretudo a social. Pela facilidade de desvinculação ou não, ressalta-se o quanto a peculiaridade do "social" é dotada de impenetrabilidade nas posições teleológicas efetivadas pelos homens. Assim, a relação entre finalidade e fundamentação cognoscitiva na esfera do ser social é muito mais significativa (LUKÁCS, 1978).

Portanto, uma vez tendo destacado apenas a base sócio-ontológica, Lukács (1978) comenta a influência das posições teleológicas individuais que impulsionam todo fato social, embora estejam presentes os nexos causais, e que a gênese dessas posições possui importantes implicações nos processos sociais. De um lado, as posições teleológicas podem se tornar determinados objetos, cuja procedência não poderia estar na objetividade natural. Por outro, toda formação social se desenvolve de tal maneira que deixa de funcionar num viés mecânicoespontâneo. O modo como uma necessidade se manifesta passa a conduzir, a constranger os homens a tomarem certas decisões teleológicas ou evitar que eles o façam.

A casualidade transcorre no processo global da sociedade em que não há uma correspondência entre a realização das finalidades e os resultados produzidos. "Essa discrepância interior entre as posições teleológicas e os seus efeitos causais aumenta com o crescimento das sociedades, com a intensificação da participação sócio-humana em tais sociedades" (LUKÁCS, 1978, p. 12). O inesperado na processualidade histórica impulsiona o comportamento material dos homens, faz com que eles se "movam" no sentido de se adequarem e aprenderem a lidar com aquela realidade. As mudanças comportamentais geram formas de agir que podem contribuir para o desenvolvimento social e para a complexificação da sociabilidade, que traz a intensificação da imprevisibilidade que circunda a objetivação do ser social. 
Destarte, a contrariedade concreta demonstra que, na história das reviravoltas mais importantes, o fator subjetivo, como é chamado por Lênin, segundo Lukács (1978), tem papel relevante.

É verdade que a diferença entre a finalidade e seus efeitos se expressa como preponderância de fato dos elementos e tendências materiais no processo de reprodução da sociedade. Isso não significa, todavia, que esse processo consiga afirmar-se sempre de modo necessário, sem ser abalado por nenhuma resistência. $\mathrm{O}$ fator subjetivo, resultante da reação humana a tais tendências de movimento, conserva-se sempre, em muitos campos, como um fator por vezes modificador e, por vezes, até mesmo decisivo. (Ibidem, p. 12-13)

O fator subjetividade entra em jogo, então, provando que, mesmo sujeito a condições reais que o cerca, o ser social é capaz de intervir de modo significativo.

Assim, entre a processualidade social/histórica e a processualidade da natureza não pode haver comparação. A articulação que se especifica se dá na medida em que há um processo dialético que começa com o salto ontológico, com o pôr teleológico do trabalho. É justamente nele que, por meio da práxis social, as formas de objetivação do ser social se promulgam no fato de o ser natural se converter cada vez mais em social.

\begin{abstract}
A existência do salto ontológico não é anulada pelo fato de esse processo, na realidade, ter sido bastante longo, com inúmeras formas de transição. Com o ato do pôr teleológico no trabalho está presente o ser social em si. O processo histórico do seu desdobramento, contudo, implica a importantíssima transformação desse ser-emsi num ser-para-si, portanto, a superação tendencial das formas e dos conteúdos de ser meramente naturais em formas e conteúdos sociais cada vez mais puros, mais próprios.

A forma do pôr teleológico enquanto transformação material da realidade material é, em termos ontológicos, algo radicalmente novo. É obvio que, no plano do ser, temos de deduzi-lo geneticamente de suas formas de transição. Também essas, porém, só podem receber uma interpretação ontológica correta quando for captado em termos ontológicos corretos o seu resultado, ou seja, o trabalho já em sua forma adequada, e quando se tentar compreender essa gênese, que em si não é um processo teleológico, a partir do seu trabalho. E isso vale não apenas para essa relação fundamental. Marx, de maneira coerente, considera essa espécie de compreensão como o método geral para a sociedade (...). (LUKÁCS, 2012, p. 287)
\end{abstract}

Nesse momento da discussão, Lukács abre um parêntese para citar um princípio fundamental do campo metodológico marxiano. Para o conhecimento da essência, estrutura e dinâmica de algum dado do real, deve-se partir do que é mais complexo para o mais simples. A objetivação, o resultado de determinada intervenção na realidade objetiva, denota suas formas de mudança, o movimento da modificação de um estado para outro por suas categorias e determinações, e revela sua gênese. E isso equivale para a apreensão das diferentes formações sociais e seus estágios de complexidade. 


\begin{abstract}
A sociedade burguesa é a mais complexa e desenvolvida organização histórica da produção. As categorias que exprimem as relações desta sociedade, e que permitem compreender a sua estrutura, permitem-nos ao mesmo tempo entender a estrutura e as relações de produção das sociedades desaparecidas, sobre cujas ruínas e elementos ela se ergueu, cujos vestígios ainda não superados continuam a arrastar consigo, ao mesmo tempo que desenvolve em si a significação plena de alguns indícios prévios, etc. A anatomia do homem dá-nos uma chave para compreender a anatomia do macaco. Por outro lado, as virtualidades que anunciam uma forma superior nas espécies animais inferiores só podem ser compreendidas quando a própria forma superior é já conhecida. Do mesmo modo, a economia burguesa dános a chave da economia da Antiguidade, etc., - embora nunca à maneira dos economistas, que suprimem todas as diferenças históricas e vêm a forma burguesa em todas as formas de sociedade. (MARX, 2015, p. 18; Grifos meus)
\end{abstract}

Sobre o conhecimento da forma superior, é possível inferir que Marx (2015) faz uma consideração que decorre a esse respeito. Relata que a última forma de sociedade deve ser capaz de realizar uma autocrítica de modo que a economia burguesa só compreendeu as organizações societárias precedentes quando começa a se criticar.

Outro ponto importante em Marx (2015, p. 16), que está relacionado ao processo de conhecimento de determinada matéria, é o entendimento de que categorias simples podem existir historicamente conservando sua autonomia antes das categorias concretas.

(...) pode afirmar-se que a categoria mais simples pode exprimir relações dominantes de um todo não desenvolvido, ou relações secundárias de um todo mais desenvolvido, relações essas que já existiam historicamente antes de o todo se ter desenvolvido no sentido expresso por uma categoria mais concreta. Só então o percurso do pensamento abstrato, que se eleva do simples ao complexo, poderia corresponder ao processo histórico real.

Ele sintetiza essa ideia dizendo que, no seu pleno desenvolvimento intensivo e extensivo, a categoria mais simples pertence a um modelo de sociedade complexo ao mesmo tempo em que, numa forma de sociedade mais atrasada, se verifica a categoria mais concreta (MARX, 2015). Assim, Lukács (2012, p. 288) põe que: "De qualquer modo, o essencial dessa compreensão metodológica continua a ser a exata separação entre a realidade existente em si como processo e os caminhos do seu conhecimento".

Retornando às instâncias da sociabilidade e da naturalidade, o que precisa ser entendido é que tanto as categorias quanto a legalidade da natureza, no âmbito da organicidade e da inorganicidade, são a fundação na qual se explicam as objetividades que se confirmam nas relações que os homens estabelecem entre si mediante o metabolismo com a natureza. No desenvolvimento social, o que se averigua é a transformação socialmente conduzida das objetividades naturais como o que acontece com o valor de uso e o valor de 
troca. A ação do homem na natureza pressupõe uma intervenção a fim de qualificar socialmente os elementos retirados do meio natural (LUKÁCS, 2012).

\begin{abstract}
(...) uma vez que a orientação de fundo do aperfeiçoamento do ser social consiste precisamente em substituir determinações naturais puras por formas ontológicas mistas, pertencentes à naturalidade e à sociabilidade (basta pensar nos animais domésticos), e continuar a explicitar, a partir dessa base, as determinações puramente sociais. A tendência principal do processo que assim tem lugar é o constante crescimento, quantitativo e qualitativo, dos componentes pura ou predominantemente sociais, aquilo que Marx costumava chamar de "recuo da barreira natural". (LUKÁCS, 2012, p. 289)
\end{abstract}

Disso aí Lukács (2012) tira uma importante conclusão sobre os fundamentos metodológicos da ontologia marxiana: uma ontologia materialista da natureza. A prioridade ontológica da economia, no âmbito da guinada materialista da ontologia do ser social, sugere a ontologia materialista da natureza na qual Marx abarca questões como a historicidade, a processualidade, a contrariedade dialética etc, presentes nas fronteiras metodológicas dele.

Marx exibe a cientificidade com que ele trata os fenômenos econômicos em suas nuances ontológicas mais densas. Isso é diferente do que ocorre com a economia na concepção burguesa de cunhar tais fenômenos puramente isolados como uma ciência particular.

\footnotetext{
A economia marxiana, ao contrário, parte sempre da totalidade do ser social e volta a desembocar nessa totalidade. Como já expusemos, o tratamento central e, sob certos aspectos, frequentemente imanente dos fenômenos econômicos encontra seu fundamento no fato de que neles deve ser buscada e encontrada a força motriz, em última análise, decisiva do desenvolvimento social em seu conjunto. (LUKÁCS, 2012, p. 291)
}

Ainda de acordo com Lukács (2012), Marx consegue mostrar claramente um modo de se fazer ciência como um complexo em sintonia com a totalidade da vida do ser social. Através da economia marxiana, ciência e ontologia são expressas no conhecimento cientificamente correto da realidade para além da aderência pragmática dos fatos imediatamente dados na sua dimensão fenomênica. Muito preocupado com antinomia existente entre fenômeno e essência, Marx a supera operacionalizando sua prática científica. Esta não deve se restringir às manifestações do fenômeno que, por vezes, obscurecem ou deformam elementos essenciais, deixando de lado determinações e vinculações objetivas.

$\mathrm{Na}$ linha tênue da oposição e da conexão entre a essência e o fenômeno, existe como possibilidade o fato de haver uma atuação manipulatória que se liga ao agir interesseiro. 


\begin{abstract}
A especificidade da relação entre essência e fenômeno no ser social chega até o agir interesseiro; e quando este, como é habitual, está baseado em interesses de grupos sociais, é fácil que a ciência abandone seu papel de controle e torne-se, ao contrário, o órgão com o qual se encobre a essência, com o qual se faz com que ela desapareça, exatamente no sentido já identificado por Hobbes. Por isso, não é casual que a frase sobre a ciência e a relação "fenômeno-essência" seja escrita por Marx no quadro de uma crítica aos economistas vulgares, em polêmica com concepções e interpretações absurdas do ponto de vista do ser, que se fecham nas formas fenomênicas e deixam inteiramente de lado as conexões reais. A constatação filosófica de Marx tem aqui, portanto, a função de crítica ontológica a algumas falsas representações, ou seja, tem por meta despertar a consciência científica no intuito de restaurar no pensamento a realidade autêntica, existente em si. (LUKÁCS, 2012, p. 295)
\end{abstract}

A interpretação que se pode ter remete para a percepção de que, quando norteada pelo agir interesseiro, a ciência é transformada em mecanismo ideológico. Usada estrategicamente, é possível que venha justificar "ontologias fictícias".

Opostamente, a apresentação que se segue é a representatividade de uma estrutura de abordagem completamente nova, caracterizadora das obras do Marx da maturidade.

(...) uma cientificidade que, no processo de generalização, nunca abandona esse nível, mas que, apesar disso, em toda verificação de fatos singulares, em toda reprodução ideal de uma conexão concreta, tem sempre em vista a totalidade do ser social e, com base nela, sopesa a realidade e o significado de cada fenômeno singular; uma análise ontológico-filosófica da realidade em si que jamais vaga, mediante a autonomização de suas abstrações, acima dos fenômenos operados, mas, ao contrário, justamente por isso, conquistou para si crítica e autocriticamente o estágio máximo da consciência, para poder captar todo ente na plena concretude da forma de ser que lhe é própria, que é específica precisamente dele. Acreditamos que, agindo assim, Marx criou uma nova forma tanto de cientificidade em geral quanto de ontologia, uma forma destinada a superar no futuro a constituição profundamente problemática, apesar de toda a riqueza dos fatos descobertos, da cientificidade moderna. (Ibidem, p. 296)

Marx deixa para as gerações posteriores o melhor de sua herança na formulação de uma nova concepção científica, visto que toda ciência tem por apoio uma fundamentação ontológica.

A análise do conceito hegeliano de sistema ganha tônica, uma vez que "aduba" esse modo peculiar de Marx interpretar o conhecimento do real. Lukács (2012) coloca traços do sistema como ideal da síntese filosófica: o princípio da completude e da conclusividade, e as categorias ordenadas numa determinada conexão hierárquica tornando-as homogêneas.

A crítica de sistema que temos em mente, e que encontramos conscientemente explicitada em Marx, parte ao contrário, da totalidade do ser na investigação das próprias conexões, e busca apreendê-las em todas as suas intrincadas e múltiplas relações, no grau máximo de aproximação possível. A totalidade não é, nesse caso, um fato formal do pensamento, mas constitui a reprodução ideal do realmente existente; as categorias não são elementos de uma arquitetura hierárquica e sistemática, mas, ao contrário, na realidade "formas de ser, determinações da 
existência", elementos estruturais de complexos relativamente totais, reais, dinâmicos, cujas inter-relações dinâmicas dão lugar a complexos cada vez mais abrangentes, em sentido tanto extensivo quanto intensivo. (Ibidem, p. 297)

Destarte, a inferência feita dessa análise indica que Marx não abandona a filosofia e lhe dá uma condição na qual o logicismo perde sua função de condução filosófica. “(...) enquanto crítica ontológica de todos os tipos de ser, a filosofia continua sendo, todavia sem a pretensão de dominar e submeter os fenômenos e suas conexões, o princípio condutor dessa nova cientificidade" (LUKÁCS, 2012, p. 297). É, pois, uma crítica ontológica intrínseca a todo fato, a toda relação, a toda conexão relativa a leis.

Dentro de uma perspectiva metodológica, é preciso compreender que, já no início, Marx separa os complexos do ser social, nos quais se observa a não dependência entre sua existência e o conhecimento correto que se tem acerca dele em menor ou maior grau, dos métodos para se apreendê-lo idealmente, reproduzi-lo a nível de consciência por um viés mais adequado possível. "A prioridade ontológica com relação ao mero conhecimento, portanto, não se refere apenas ao ser em geral; toda objetividade é, em sua estrutura e dinâmica concretas, em seu ser-propriamente-assim, da maior importância do ponto de vista ontológico" (LUKÁCS, 2012, p. 303). Marx trabalha desde a época dos Manuscritos econômico-filosóficos com o pressuposto da prioridade ontológica envolvida nas interrelações entre objetividades como uma configuração procedente de toda relação ontológica entre entes (LUKÁCS, 2012).

Numa escala de anterioridade ontológica, trata-se de casos nos quais o conhecimento concreto de algum ser-propriamente-assim é secundarizado ante os nexos que são estabelecidos entre as objetivações, demonstrações ontológicas de sua existência em si, desencadeadas por ele e outros seres. Consequentemente, pensar a prioridade ontológica de determinado ser só é possível se for própria dele a capacidade de objetivação. Dito isso, Marx faz revides em dois sentidos. Primeiro, as concepções segundo as quais haveria uma posição privilegiada de determinados elementos "últimos" do ser em detrimento aos elementos mais complexos, mais compostos. Depois, a concepção, no caso destes últimos, de que as funções sintéticas do sujeito cognoscente exerceria certa influência no quê e no como de sua objetividade (LUKÁCS, 2012).

Lukács (2012) discute que a verificação de que o ente originário é sempre uma totalidade dinâmica, uma unidade de complexidade e processualidade, sendo a objetividade uma propriedade ontológica primária de todo ente. É um acometimento contrário ao que diz o influxo kantiano. Para Marx, a posição ontológica da categoria totalidade se apresenta de 
modo muito mais imediato para o ser social do que para a natureza e toda sociedade constitui uma totalidade. Contudo, apenas como uma expressão do princípio mais geral, e não a essência, a constituição dessa totalidade e tampouco os dados mais imediatos a fim de conhecê-la de modo mais acertado.

$\mathrm{Na}$ “Introdução” de 57, Lukács (2012) adverte que Marx responde algumas teses se ocupando de um método que se desloca de abstrações à concretude. Ele prescreve o referencial das abstrações que viabilizam a chegada a uma totalidade composta de muitas determinações e relações.

\footnotetext{
Por conseguinte, se começássemos simplesmente pela população, teríamos uma visão caótica do conjunto. Por uma análise cada vez mais precisa chegaríamos a representações cada vez mais simples; do concreto inicialmente representado passaríamos a abstrações progressivamente mais sutis até alcançarmos as determinações mais simples. Aqui chegados, teríamos que empreender a viagem de regresso até encontrarmos de novo a população - desta vez não teríamos uma ideia caótica de todo, mas uma rica totalidade com múltiplas determinações e relações. (MARX, 2015, p. 14)
}

Destarte, a "viagem de retorno" não mais apresenta uma "representação caótica do todo”, mas a riqueza daquela realidade. “(...) 'as abstrações mais tênues' e as 'determinações as mais simples' vão sendo carregadas das relações e das dimensões que objetivamente possuem e devem adquirir para reproduzir (no plano do pensamento) as múltiplas determinações que constituem o concreto real” (PAULO NETTO, 2011, p. 53-54).

A prerrogativa é a de que conhecimento teórico da realidade concreta é o caminho de torná-la menos indeterminada de modo a se ter constantemente presente a dependência ao ser social e uma permanente crítica ontológica das conexões categoriais reais. Quer se parta da realidade imediatamente dada ou de seus complexos parciais, o conhecimento imediatamente direto de realidades imediatamente dadas se distende em meras representações. Estas precisam ser mais bem determinadas por abstrações isoladoras. Há um duplo movimento: da "representação plena" surge "determinações abstratas" e estas levam à reprodução do concreto através da esfera do pensamento. Essas informações são melhor entendidas em Marx (2015, p. 14-15):

O concreto é concreto porque é a síntese de múltiplas determinações e, por isso, é a unidade do diverso. Aparece no pensamento como processo de síntese, como resultado, e não como ponto de partida, embora seja o verdadeiro ponto de partida, e, portanto, também, o ponto de partida da intuição e da representação. No primeiro caso, a representação plena é volatilizada numa determinação abstrata; no segundo caso, as determinações abstratas conduzem à reprodução do concreto pela via do pensamento. Eis por que Hegel caiu na ilusao de conceber o real como resultado do 
pensamento que, partindo de si mesmo se concentra em si mesmo, se aprofunda em si mesmo e se movimenta por si mesmo; ao passo que o método que consiste em elevar-se do abstrato ao concreto é, para o pensamento, apenas a maneira de se apropriar do concreto, de o reproduzir na forma de concreto pensado; porém, não é este de modo nenhum o processo de gênese do concreto em si. (Grifos meus)

Marx revela, nesse trecho, dois métodos. O primeiro método, ao considerar o concreto que não é concreto mais, deixa de compreender as determinações que compõem o concreto real. Seu "em-si" assume uma condição puramente abstrata e ele não é tido como um ponto de partida, mas um produto da ação do pensamento. Essa deturpação do concreto ocasiona a falta de entendimento de muitas das determinações próprias dele, uma vez que o pensamento só capta aquilo que é aparente. No segundo, o método cientificamente correto, o pensamento se movimenta de forma que o abstrato ascende ao concreto e as determinações abstratas orientam a reprodução do concreto pensado. Para Marx, a "falha" de Hegel foi idealizar um movimento autônomo do pensamento, da consciência, que não procede. $\mathrm{O}$ ato de produção do concreto em si decorre da realidade objetiva tal como ela é. Em certo sentido, Lukács (2012, p. 288) explica a razão do surgimento da ilusão idealista de Hegel na exagerada justaposição ou até na supremacia entre a cognoscibilidade e a ontologia que Marx rebate:

(...) precisamente porque o processo ontológico do ser e da gênese é aproximado em demasia do processo do compreender, necessário no plano cognoscitivo; aliás, este último chega a ser entendido como um substituto e até mesmo como uma forma ontologicamente superior do primeiro.

Esse método de ascensão do abstrato ao concreto se afasta da instigação idealista de conceber o real como resultado do pensamento de duas formas (LUKÁCS, 2012). Primeiramente, porque o caminho do processo cognoscitivo feito pela mediação dos "elementos" alcançados pela abstração até o conhecimento da totalidade concreta pertence apenas ao conhecimento e não é a própria realidade. Ela é constituída por interações reais e concretas e suas mudanças acondicionam a determinação de sua gênese. $O$ real e seu conhecimento são de ordens distintas e, por isso, não têm correspondência entre suas procedências ontológicas. Em sentido contrário, se reconhece ainda o quanto necessários são os "elementos" dos processos racionais para o conhecimento da realidade. São parcialidades processuais do ser, mas de constituição mais simples, o que, consequentemente, "facilita" a apreensão conceitual diferente dos complexos totais dos quais fazem parte. Grande importância têm, então, observações empíricas e experimentos ideais abstrativos para se atingir a regulação por leis de seu funcionamento alheio a influências externas. 
Marx (2015, p. 15) trabalha com o modo como está posta a funcionalidade da totalidade concreta pensada.

\begin{abstract}
(...) a totalidade concreta, enquanto totalidade do pensamento, enquanto concreto do pensamento é in fact um produto do pensamento, do ato de conceber; não é de modo nenhum, porém, produto do conceito que pensa e se gera a si próprio e que atua fora e acima da intuição e da representação; pelo contrário, é um produto do trabalho de elaboração, que transforma a intuição e a representação em conceitos. $\mathrm{O}$ todo, tal como aparece na mente como um todo pensamento, é produto da mente que pensa e se apropria do mundo do único modo que lhe é possível; modo que difere completamente da apropriação desse mundo na arte, na religião, no espírito prático.
\end{abstract}

A consistência profícua do todo concreto do pensamento é apresentada como parte do caminho metodológico para a ascensão às categorias conceituais por meio de uma produção provável e determinada de pensar e se apossar do mundo. O único modo possível subentendido é o processo de conhecimento que se diferencia de maneiras específicas de apropriação desse mundo de outros complexos.

No que tange ao processo de conhecimento da totalidade pelo método da economia política, Lukács (2012, p. 306) faz uma advertência:

\begin{abstract}
É, claro, portanto, que o método da economia política, que Marx designa como uma "viagem de retorno", pressupõe uma cooperação permanente entre o procedimento histórico (genético) e o procedimento abstrativo-sistematizante, os quais evidenciam as leis e as tendências. A inter-relação orgânica, e por isso fecunda, dessas duas vias do conhecimento, todavia, só é possível sobre a base de uma crítica ontológica permanente de todos os passos dados, já que ambos os métodos têm como finalidade compreender, de ângulos diversos, os mesmos complexos da realidade. A elaboração puramente ideal, por conseguinte, pode facilmente cindir o que forma um todo no plano do ser, e atribuir às suas partes uma falsa autonomia, não importando se isso sucede em termos empírico-historicistas ou termos abstrativo-teóricos.
\end{abstract}

Daí decorre a constante vigilância da crítica ontológica para reconstituir na mente a inteligibilidade dos fenômenos.

Um outro ponto é a não redução de contraste entre a totalidade e seus "elementos". Entre ambos, existe uma complexidade que é própria a cada um deles. Ou seja, ao "elemento", uma parcialidade, reportar-se a um complexo de propriedades concretas, qualitativamente específicas, um complexo operado por forças e relações diversas. Todavia, sua qualidade de "elemento" não é suprimida. Portanto, Lukács (2012) destaca que, embora as autênticas categorias econômicas ${ }^{21}$ possam receber um trato teórico-analítico particular, elas não podem ser apartadas da totalidade que envolve a ordem social.

\footnotetext{
${ }^{21}$ Lukács (2012) fala da grandeza dos fundadores da economia política ao ter percebido o caráter fundante das categorias autênticas e ter dado o "ponta pé" na instituição das relações corretas entre elas.
} 
Por conseguinte, “(...) é a própria essência da totalidade econômica que prescreve o caminho a seguir para conhecê-la" (LUKÁCS, 2012, p. 304). O objeto faz a indicação do material histórico-social que precisa ser acessado e as mediações que necessitam ser feitas para o descobrimento processual das categorias e determinações atuantes naquela totalidade. Diga-se, de passagem, indicação, porque também transcorre a seleção de técnicas e instrumentos de pesquisa para a investigação.

Em conformidade com Lukács (2012), nas relações que as categorias podem constituir estão inclusas a coordenação paritária, a sobreordenação e a subordinação. Parece haver uma contradição no que se refere às censuras da hierarquização no sistema idealista, mas é uma contradição ilusória. O que precisa ser feito é a distinção entre o princípio da prioridade ontológica e os juízos de valor gnosiológicos, morais, etc. "Quando atribuímos uma prioridade ontológica a determinada categoria com relação a outra, entendemos simplesmente o seguinte: a primeira pode existir sem a segunda, enquanto o inverso é ontologicamente impossível" (LUKÁCS, 2012, p. 307). A prioridade ontológica assinala condições fundamentais que regem a materialidade de entes ontologicamente distintos.

Como exemplos de situações em que há prioridade ontológica, são colocados estes dois: 1) o ser tem prioridade ontológica com relação à consciência. Isso denota que um ser pode existir sem consciência, no entanto, para garantir sua existência, a consciência exige como fundação algum ente. Não há nenhuma hierarquia de valor entre eles. As pesquisas ontológicas mostram que formas cada vez mais explícitas de consciência são encontradas somente a nível do ser social; 2) existe prioridade ontológica da produção e reprodução do ser humano em relação às outras funções (política, arte, religião, etc). Marx (1919, p. 8 apud LUKÁCS, 2012, p. 308) “(...) afirma, por um lado, que à superestrutura "correspondem formas determinadas de consciência social" e, por outro lado, que "o modo de produção da vida material condiciona, em geral, o processo social, político e espiritual da vida". Está nas relações de produção o fundamento para determinadas formas de consciência. A consciência precisa ser iluminada não a partir dela mesma, mas pelas contradições da vida material. Essas formas de consciência também são condicionadas por outras instâncias da vida social, porquanto, partem da totalidade do ser social e não da estrutura econômica estrita (LUKÁCS, 2012).

Em relação à prioridade ontológica das categorias econômicas, Marx (2015) faz pontuações indispensáveis. Ele coloca, inicialmente, que, como em toda ciência histórica e social, ao se analisar o desenvolvimento das categorias econômicas, há de se considerar que o sujeito, no caso, a sociedade burguesa, está dado tanto na realidade quanto no pensamento. E, 
por isso, as categorias traduzem “(...) formas e modos de existência, amiudadamente simples aspectos desta sociedade, deste sujeito" (Ibidem, p. 19). De tal modo, na especificação das categorias econômicas, tem-se que, em todas as organizações sociais, uma forma dominante de produção que se sobressai colocando as diferentes em seus devidos lugares, ou seja, “(...) os limites e a importância de todas as outras e cujas relações determinam, portanto, os limites e a importância das outras" (Ibidem, p. 19). A ligação com a natureza prevalece acentuada nas sociedades em que há o domínio da propriedade agrária ao passo que naquelas em que o capital é hegemônico, os elementos produzidos social e historicamente são os que possuem predomínio. Nesse sentido,

\begin{abstract}
Não está em causa a posição que as relações econômicas ocupam historicamente na sucessão das diferentes formas de sociedade; nem tampouco a sua ordem de sucessão"na ideia" (Proudhon), (uma representação nebulosa do movimento histórico). O que nos interessa é a sua estruturação no interior da moderna sociedade burguesa. (MARX, 2015, p. 20)
\end{abstract}

Fica clara, portanto, a inexistência de uma ordenação. O que importa é uma posição, mas aquela ocupada na estrutura categorial do sistema econômico na sociabilidade capitalista. Depois de identificada a categoria mais fundamental das relações de produção, sempre por um ponto de vista ontológico, as outras vão aparecendo na medida em que o movimento do real estiver reduzindo seu grau de indeterminação.

Após esse adendo metodológico, Lukács (2012) volta para a temática do método da economia política por um radar teórico-metodológico na descrição d'O capital como manifestação do formato mais sofisticado desse método, o livro conclusivo. O que ele faz como manobra de ação é se utilizar desse método para discorrer sobre ele mesmo na tentativa de pontuar generalidades dos princípios determinantes para a construção desse texto. Ele migra de um amplo processo de abstração para abrir a passagem, etapa após etapa, para a apropriação ideal da totalidade concreta e articulada.

Diante da precisão de experimentos ideais de abstração para a investigação do complexo econômico, Marx adquire uma posição especial em relação a alguns pensadores, mesmo com a positividade do fato de eles já estarem sendo norteados por um claro senso da realidade e uma conveniente tendência para o fator ontológico. Ele possuía algo a mais.

Marx se distingue, em relação aos seus mais significativos precursores, sobretudo pelo senso da realidade, tornando consciente e intensificado pelo conhecimento filosófico tanto na compreensão da totalidade dinâmica quanto na justa avaliação do quê e do como de cada categoria singular. (LUKÁCS, 2012, p. 309-310) 
O algo a mais dele está na potencialidade da aplicação de determinada forma de se orientar por uma visão analítica pautada numa concepção filosófica que passa a ser o artefato teórico catalisador de abstrações metodologicamente indispensáveis e de mediações essenciais às conexões reais que levam seu senso da realidade para mais adiante dos limites da pura economia. O estabelecimento da interação entre a economia propriamente dita e a realidade extraeconômica no conjunto da totalidade do ser social elucida questões filosóficas que, em outras ocasiões, não poderiam ser resolvidas (LUKÁCS, 2012).

Lukács (2012) declara que a permanência de uma crítica e autocrítica ontológica fornece ao experimento ideal abstrativo da pura economia uma dimensão epistemológica ímpar, pois traz para ela uma nova forma de abstrair que não é isoladora ou parcial, vez que as abstrações são oriundas de todo o eixo da economia.

\footnotetext{
Esse método dialético peculiar, paradoxal, raramente compreendido, baseia-se na já referida convicção de Marx de que, no ser social, o econômico e o extraeconômico convertem-se continuamente um no outro, estão numa irrevogável relação recíproca, da qual, porém não deriva, como mostramos, nem um desenvolvimento histórico singular sem leis, nem uma dominação mecânica "por lei" do econômico abstrato e puro, mas da qual deriva, ao contrário, aquela orgânica unidade do ser social, na qual cabe às leis rígidas da economia precisamente e apenas o papel de momento predominante. (LUKÁCS, 2012, p. 310)
}

O experimento pode se conservar, portanto, em invariável articulação com a totalidade do ser social em termos de relações, tendências etc, que não estão na economia.

Esta influência mútua entre econômico e extraeconômico transcorre intimamente na teoria das categorias. Lukács (2012) vem dizer que Marx dá continuidade à expectativa da economia política clássica, quando situa o salário na teoria geral do valor. Entretanto, intui que a força de trabalho tem, no valor de uso, a condição de ser fonte de valor: a atividade do trabalho cria valor. Ele se limita a destacar que, dentre as implicâncias desse descobrimento, está o fato de que a mercadoria força de trabalho é dotada de nuances extraeconômicas na efetivação da lei do valor. Diferente de outras mercadorias em que seus valores são extremados pelos custos de produção, a força de trabalho contém fatores históricos e morais que Marx explica a partir da luta entre trabalhadores e capitalistas pela jornada de trabalho com a antinomia de direitos de ambos legitimados na lei de troca de mercadorias, nas dimensões de sua venda e seu consumo. Outro aspecto identificado por Marx são as duas faces de uma mesma moeda: o surgimento do extraeconômico diante da necessidade da própria lei de valor na ininterrupção de trocas de mercadoria e como os atos de violência extraeconômicos condicionaram a força de trabalho a ser uma mercadoria particular que é 
base das leis teóricas da economia política (LUKÁCS, 2012). Pelas duas vias possíveis, Marx localiza a presença dialética do extraeconômico, tanto no âmbito da própria estrutura produtiva e da esfera econômica como também em condicionamentos que propulsionam o movimento de leis econômicas.

Segundo Lukács (2012), a estrutura d'O capital só se torna inteligível se houver a consideração dos intercâmbios do econômico com relações e forças exógenas a ele. São colocadas, a partir de experimentos, as conexões legais puras, homogêneas a nível de abstração, assim como as influências exercidas até por aspectos mais amplos, associadas à realidade a fim de se atingir a totalidade do ser social. Já na primeira redação, Marx sugere sua intenção de se aproximar e concretizar isso nesta obra. Para tanto, o caminho percorrido não deve ser orientado por uma abstração qualquer, mas por aquela que obtenha centralidade enquanto categoria do plano ontológico. É por isto que, n'O capital, Marx começa sua investigação pelo "valor" partindo inicialmente de sua gênese. Uma gênese que apresenta toda a realidade econômica sinteticamente, por abstração, através da redução em um momento crucial e sua fertilidade em evidenciar o caráter social da produção.

A gênese do valor descrita por Marx esclarece, de imediato, o duplo caráter do seu método: essa gênese não é nem uma dedução lógica do conceito de valor, nem uma descrição indutiva das fases históricas singulares do desenvolvimento que o levou a adquirir a forma social pura; ao contrário, é uma síntese peculiar de novo tipo, que associa de modo teórico-orgânico a ontologia histórica do ser social com a descoberta teórica das suas legalidades concretas e reais. (LUKÁCS, 2012, p. 312313)

Nesse debate introdutório, Marx não pretende esgotar a origem histórica do valor na vida econômica. $\mathrm{O}$ modo como ele traceja o automovimento dessa categoria acaba por gerar a coincidência de suas fases histórico-ontológicas e aquelas teóricas, o que, por sinal, insinua sua posição preponderante no sistema econômico. Por causa disso, seria algo errôneo e aligeirado tomar como prerrogativa um "paralelismo absoluto" entre o desenvolvimento histórico e o desenvolvimento teórico enquanto fundamento metodológico de toda a economia.

Tão somente porque no valor, enquanto categoria central da produção social, confluem as determinações mais essenciais do processo global, é que a exposição abreviada, reduzida, dos fatos decisivos, das etapas ontológicas da gênese, possui ao mesmo tempo o significado de fundamento teórico também das etapas econômicas concretas. (LUKÁCS, 2012, p. 313) 
Assim sendo, essa posição da categoria valor é um fato ontológico. Sua análise teórica demonstra imediatamente como ela é um fator importantíssimo para tendências de toda a realidade social. Lukács (2012), de maneira concisa, traz alguns momentos relevantes. Primeiramente, como categoria social, emerge do valor o trabalho, fundamento primeiro do ser social. A vinculação do trabalho com as funções sociais do valor denota os princípios estruturadores fundamentais do ser social que decorrem dos nexos dialéticos reais do natural e do social. "A inseparabilidade, que se expressa como contradição entre valor de uso e valor de troca, revela sua ligação, que se apresenta como antética, mas que é também indissolúvel, essa propriedade ontológica do ser social” (LUKÁCS, 2012, p. 314). Na dialética do valor, realizase a indissociabilidade entre a materialidade natural e a social dada a superação dessa naturalidade por processos de transformação no sentido da sociabilidade que marca categorias cada vez mais sociais.

O segundo momento envolve a análise marxiana do valor através do exercício de abstrair totalmente moderno aos padrões que acarretam a incompreensão da dialética do valor por meio da sanção dos elementos da materialidade objetivamente posta como produtos imediatos do pensamento por uma hipotética atuação autônoma da consciência.

\begin{abstract}
A metamorfose do trabalho, em ligação com a relação cada vez mais explicitada entre valor de uso e valor de troca, transforma o trabalho concreto sobre um objeto determinado em trabalho abstrato que cria valor, o qual culmina na realidade do trabalho socialmente necessário. Quando se examina esse processo de abstração sem se enredar na metafísica idealista, é impossível não ver como ele é real no âmbito da realidade social. Já indicamos, em outros contextos, que o caráter médio do trabalho surge de modo espontâneo, objetivo, desde os graus mais primitivos de sua sociabilidade; que esse caráter não é mera representação ideal da constituição ontológica do próprio trabalho, no curso de sua crescente socialização, categoria que só bem mais tarde é teoricamente alçada à consciência. Também o trabalho socialmente necessário (e, desse modo, ipso facto abstrato) é uma realidade, um momento da ontologia do ser social, uma abstração real de objetos reais, que se dá de modo inteiramente independente da circunstância de que seja ou não realizada também pela consciência. (LUKÁCS, 2012, p. 315)
\end{abstract}

Valendo-se da ligação do trabalho com a categoria do valor, Marx especifica, no modo peculiar de dar tratamento à abstração, como esta tem a mesma concretude ontológica que a faticidade (LUKÁCS, 2012). Isso ocorre porque as abstrações podem exercer intervenções efetivas na realidade objetiva.

Também as relações e as conexões precisam ser observadas num viés analítico semelhante. Lukács (2012) assinala que, a respeito delas, Marx vai mais além, visto que argumenta tanto sobre como relações e conexões são partícipes ontológicos do ser social quanto o fato de não se poder lutar contra sua facticidade, que na vida prática acarreta a 
transformação delas em coisidades no plano do pensamento. São indícios, pois, de que a manifestação primitiva da intentio recta ontológica induz a consciência dos homens à reificação, a qual Marx, quando fala do fetichismo da mercadoria, demonstra que o processo de reificação das relações e conexões sociais compõe o princípio fundante da deformação ontológica que atinge categorias econômicas e objetos espirituais mais elaborados e proeminentes da vida dos homens.

Regressando ao arcabouço elaborativo global do Livro I, de $O$ capital, Lukács (2012) o retoma com a discussão que ressalta a prioridade do ontológico e de um princípio ontológico fundamental de uma metodologia rigorosamente científica. Ele traz “(...) que a aparência de uma 'construção a priori' tem sua origem tão somente no modo de exposição, não dizendo respeito à investigação enquanto tal" (Ibidem, p. 316). Esse trecho referencia, dentro dos limites dos processos investigativos e expositivos, o aparecimento do dinheiro da forma geral do valor entendido como uma necessidade do ser e que a "dedução" de Marx acerca desse aparecimento só é vista como lógica porque é uma abstração, breve e comprimida aos aspectos mais gerais com a qual é exposta. Rompe-se a "logicidade" que pode ser restrita ao pensamento a partir do entendimento do dinheiro como uma consequência "logica" do valor com um certo teor especulativo. Nesse sentindo, do ponto de vista ontológico, a função de desempenhar um controle e uma crítica ontológica permanentes, assim como fazer generalizações ampliadas e aprofundadas, é da filosofia (LUKÁCS, 2012).

Uma generalização de cunho filosófico não reduz a precisão científica de análises de teorias econômicas singulares. Elas são inseridas em encadeamentos necessários à adequada compreensão da totalidade do ser social. Considerando a exposição rigorosa científica da gênese ontológica de categorias decisivas como o valor e o dinheiro, dentro de ramo científico especializado, tem-se a provável falsificação da essência ontológica dessas categorias através de uma falsa aparência de uma racionalidade pura do percurso histórico real. Essa racionalidade pura incide não apenas sobre a essência de processos econômicos singulares, mas também no processo econômico total, mesmo que tendencialmente.

Todavia, não se deve jamais esquecer que essas legalidades são decerto sínteses que a própria realidade elabora a partir dos atos práticos econômicos singulares, realizados de modo consciente enquanto tais, mas cujos resultados últimos, que são os fixados pela teoria, ultrapassam em muito a capacidade de compreensão teórica e as possibilidades de decisão prática dos indivíduos que realizam efetivamente esses atos práticos. (LUKÁCS, 2012, p. 317) 
Portanto, existe uma lei que leva os homens a assumirem, de forma fenomênica, um “destino" transcendente em função dos resultados de atos econômicos singulares realizados na prática social (e conscientemente) (LUCÁKS, 2012).

Ao comentar que isso não acontece apenas com o dinheiro, Lukács (2012) discorre sobre como isso também se manifesta na estrutura da relação entre teoria e práxis social, remetendo-se a Marx. Desse modo, aponta a prioridade da práxis na orientação e no controle do conhecimento, explanando o método para definir a via mediadora que a leva como a interação entre teoria e práxis que surge no ser social. "Disso resulta que toda práxis, mesmo a mais imediata e a mais cotidiana, contém em si essa referência ao ato de julgar, à consciência etc, visto que é sempre um ato teleológico, no qual o pôr da finalidade precede, de modo objetivo e cronológico, a realização" (LUKÁCS, 2012, p. 317).

No entanto, isso não significa que seja possível saber quais serão as implicações dos atos singulares, sobretudo quando integralizar uma modificação da totalidade do ser social, uma vez que o agir social e o agir econômico abrem brechas para forças, tendências, objetividades, estruturas etc, provenientes da práxis humana, que, no todo ou em partes, despontam como incompreensíveis para quem a executa. É importante trazer que essas considerações escapam ao terreno da economia (também de suas teorias) e sua história chegando, ao passar pela ciência e pela filosofia, a todos os outros processos no âmbito do ser social e da consciência.

A gênese ontológica revela novamente, nesse contexto, o seu poder totalmente abrangente: uma vez estabelecida essa relação entre práxis e consciência nos fatos elementares da vida cotidiana, os fenômenos da reificação, do fetichismo, do estranhamento, como cópias feitas pelo homem de uma realidade incompreendida, apresentam-se não mais como expressões arcanas de forças desconhecidas e inconscientes no interior e no exterior do homem, mas antes como mediações, por vezes bastante amplas, que surgem na práxis mais elementar. (LUKÁCS, 2012, p. 318)

Assim sendo, é correto afirmar que a nível da especificidade do ser social essa incompreensão da realidade por parte da consciência é um fato ontológico que passa a existir como um efeito que é próprio da práxis. Para o homem, está a impossibilidade de atingir totalmente as forças atuantes em suas práxis.

A seguir, são proporcionados por Lukács (2012) os elementos que Marx usa para debater acerca de uma teoria ontológica do desenvolvimento social no sentido de trazer a consumação de qualquer complexo de fatos e de qualquer categoria num direcionamento assentado na genuinidade social. Por meio da exposição marxiana do dinheiro e da força de 
trabalho, vai sendo elucidada a primeira produção propriamente dita, o capitalismo, em que as idas e vindas em relação às formações sociais mais primitivas acabam por determinar o caráter social do modo de produção capitalista e, tão logo, o movimento do afastar-se das "barreiras naturais" no formato de conteúdo e de categorias.“(...) o estudo ontológico do ser social mostra que só de modo bastante gradual, passando por muitíssimas etapas, é que suas categorias e relações adquiriram o caráter de sociabilidade predominante" (LUKÁCS, 2012, p. 319). O desenvolvimento do ser social é movido pela predominância de categorias que se recuam nitidamente em suas qualificações naturais para incorporar disposições cada vez mais dotadas de sociabilidade. Isso é o que acontece em situações como na circulação de mercadorias em que produtos da natureza são substituídos pelo dinheiro; na relação entre mais-valor absoluto e mais-valor relativo; e na introdução de máquinas no sistema fabril, colocando de lado fatores determinantes do trabalho - o homem e sua capacidade de trabalho (LUKÁCS, 2012).

Tais situações comprovam como esse desenvolvimento tem um traço ontológico, haja visto que desponta aquilo que se processa com as categorias decisivas da economia em direção à superação da ligação inata com a natureza. Lukács (2012) permanece pronunciando que, além de um processo de desenvolvimento, há também, nesse sentido, um progresso que se realiza como uma constatação ontológica e não uma avaliação ou uma tomada de posição subjetivamente axiológica. O progresso se dá na medida em que o ponto central é o ser social, um novo ser que se explicita em sua condição de interdepender suas categorias e manter as formas naturais apenas a título de uma crescente superação.

A partir da reflexão de Marx na referenciação alusiva do desenvolvimento das forças produtivas ao desenvolvimento do gênero humano, Lukács (2012) traz que ela se atém a uma visão da objetividade ontológica que se agrega ao quadro do desenvolvimento primeiro. Como Marx cita contradições dessa realidade, ele descobre que elas são apenas manifestações aparentes, as quais, no plano ontológico, são necessárias e objetivas, que participam do progresso econômico, que é a essência do desenvolvimento ontológico. Portanto, está nos alcances da ontologia do ser social a contradição que se processa diante do crescimento cultural do gênero humano efetivado somente em prejuízo de todas as classes humanas, não coincidindo com o desenvolvimento do indivíduo singular e que o alto desenvolvimento da individualidade só pode ser possível em face de um processo histórico de sacrifício de indivíduos.

Pensando ainda a questão das várias instâncias de desenvolvimento que compõem a totalidade do ser social, é importante apontar o desenvolvimento "base" que condiciona todos 
os demais, o econômico. As considerações se limitam a demarcar a presença de três orientações evolutivas desse desenvolvimento (LUKÁCS, 1978):

1) A tendência constante da diminuição do tempo de trabalho socialmente necessário à reprodução dos homens;

2) O processo de reprodução se torna cada vez mais social. Os diferentes momentos decisivos da reprodução humana adquirem, com mais intensidade, momentos sociais pelos quais são constante e essencialmente modificados;

3) O desenvolvimento econômico, pelo menos no que se refere a princípios econômicos reais de unidade, tem criado conexões quantitativas e qualitativas cada vez mais intensas e fortes entre os povos do mundo inteiro, abrindo brechas para os mais "graves e ásperos" conflitos humanos.

Todas essas três orientações são casos que se exibem diante das tendências importantes e decisivas da transformação do ser social na qual ele atinge uma forma que lhe é própria. São indicativos do processo de humanização: “(...) o homem deixa a condição de ser natural para tornar-se pessoa humana, transforma-se de espécie animal que alcançou um certo grau de desenvolvimento relativamente elevado em gênero humano, em humanidade" (LUKÁCS, 1978, p. 15). Tudo isso é fruto das séries causais que emanam do conjunto da sociedade. O progresso em si não tem um desígnio, visto que, em seu desenvolvimento, em direção a graus de superioridade, ativam contradições. Síntese de atividades humanas, o progresso não reside no aperfeiçoamento de uma teleologia qualquer e, por essa razão, há uma contínua destruição de resultados economicamente limitados e a aparição de novos conflitos sociais. "É assim que surgem, a partir da comunidade primitiva dos homens, antinomias aparentemente insolúveis, isto é, as oposições de classe; de modo que até mesmo as piores formas de inumanidade são o resultado desse progresso" (LUKÁCS, 1978, p. 15). O progresso econômico carrega, assim, uma dupla face: da causalidade e da contradição. Ao mesmo tempo que incita os êxitos das posições teleológicas dos homens, ele também contribui para a ampliação das desgraças humanas.

Continuando ainda no Livro I, de $O$ capital, Lukács (2012) afirma que ele tem uma figuração bastante paradoxal de conteúdo e de método. As análises econômicas são estabelecidas através de perspectivas tangenciadas ontologicamente na totalidade do ser social 
em uma dimensão científica rígida e exata. Nesta se percebe uma tendência básica de Marx, criadora da atmosfera de proximidade com a vida: “desenvolver as generalizações fillosóficas a partir dos fatos verificados pela investigação e pelo método científicos, ou seja, a constante fundação ontológica das formulações tanto científicas quanto filosóficas” (Ibidem, p. 321).

O ponto de partida repousa na abstração econômica, que funciona como uma premissa, segundo a qual o valor de todas as mercadorias é o que rege seus momentos de compra e venda. De fato, é uma abstração sui generis, cuja base contém a lei fundamental e efetiva da circulação social de mercadorias, que se realiza sempre na realidade econômica, mesmo com as oscilações de preços numa totalidade com padrões de normalidade. Essa abstração afirma algo que é essencial no novo método de Marx, quando o tipo e o sentido das abstrações são determinados pela essência ontológica do assunto tratado. Tem-se que essa redução abstrativa ao item mais essencial evidencia a lei fundamental da circulação de mercadorias sem os riscos de ser uma abstração não fundada ontologicamente, acarretando uma possível deformação das categorias decisivas.

Em razão do aspecto ontológico da abstração, o Livro I não é tido como um experimento abstrativo ideal, mas como a reprodução da realidade. Ele lida tanto com uma abstração quanto com dados do mundo real. Sua construção denota a introdução de novos elementos e tendências ontológicas no mundo reproduzido idealmente fundado, a princípio, nessa abstração. A compreensão da totalidade da economia como "centro motor primário do ser social" advém pelas vias científicas de novas categorias, tendências e conexões surgidas ante essa totalidade. Em seguida, o próximo passo leva ao próprio processo em sua totalidade, entendido primeiramente em sua generalidade.

De fato, no Livro I, embora o pano de fundo seja sempre a totalidade social, as
exposições teóricas centrais captam apenas os atos individuais (...). Dali em diante,
importa examinar os processos, até aquele momento conhecidos singularmente, em
toda a sua sociabilidade. Marx observa repetidamente que a primeira exposição dos
fenômenos foi abstrata e, portanto, formal. (...) Só quando o processo global é
investigado quanto às suas leis, relativas à totalidade da economia, é que essa
apreensão formal deixa de ser suficiente (...). (LUKÁCS, 2012, p. 323; Grifos
meus)

A via que remete à passagem dos processos singulares ao processo do conjunto parte da pressuposição não de uma abstração mais abrangente, pelo contrário, da superação de determinados limites da abstração, uma aproximação introdutória à concretude da totalidade pensada. Nesse sentido, Lukács (2012) ressalta a inviabilidade de uma síntese detalhada e profunda do que traz o Livro II. A preocupação é ilustrar os problemas mais fundamentais 
desse estágio por meio do seu significado ontológico. Assim, a discussão é feita a partir do processo global de reprodução econômica que é a unidade de três processos, cada qual com três níveis - os ciclos do capital-dinheiro, do capital produtivo e do capital-mercadoria. São três processos econômicos reais que se articulam num processo unitário em que a decomposição em conceitos distintos reflete o pensamento dos três processos da reprodução, a saber: o capital industrial, o capital comercial e o capital monetário. Embora eles tenham em comum conteúdos, elementos, níveis e sequência, a diferença entre eles é o momento no qual um tem início e no qual acabam gerando um movimento cíclico e agregando um processo produtivo particular que não elimina a continuidade do processo de reprodução social (LUKÁCS, 2012).

A perspectiva analítica desses três ciclos oferta as proporções mais acentuadas da sociedade capitalista. Para apontar as proporcionalidades obtidas, Marx, simultaneamente, dilui abstrações do Livro I e trabalha com uma nova abstração que parte da reprodução simples para chegar na verdadeira reprodução, a reprodução ampliada. Para o correto entendimento em termos metodológicos marxianos, põe-se, mais uma vez, que a abstração constatada é partícipe da realidade na medida em que sua consecução implica o reflexo do processo real em suas verdadeiras determinações, ainda que diante de sua incompletude de forma. Por outro lado, a problemática encontrada no fato do aumento da produtividade não ser estimado na abstração explicativa da passagem para reprodução ampliada traz uma ilustração. Essa plasticidade do método abstrativo de Marx, em função de seu caráter ontológico, permite sucessivas concreções sem precisamente modificar as bases metodológicas, mesmo que a inserção do aumento da produtividade constitua novas determinações surgidas e uma nova dimensão no anexo de conexões (LUKÁCS, 2012).

$\mathrm{Na}$ observância de que as proporções são resultantes de complexos qualitativamente determinados, Lukács (2012) vai afirmar, entre outros pormenores, que as proporções qualitativas de valor devem conter obrigatoriamente os valores de uso qualitativamente variados, os quais são articulados numa visão ontológica, sendo esta uma realização que o Livro II concebe em relação ao Livro I. Ele salienta, de modo complementar, que

(...) para a restauração do marxismo autêntico, não é supérfluo sublinhar que é a intectio recta ontologicamente verdadeira que forma a base da ciência e da generalização filosófica, que nenhum fenômeno econômico pode ser compreendido de maneira correta sem que se parta das próprias conexões reais - neste caso, da inseparabilidade ontológica do valor de uso e valor de troca justamente em sua antiteticidade. (Ibidem, p. 326) 
De acordo com essa ponderação, torna-se possível apreender que Marx esmiúça ainda mais as abstrações iniciais somente com a aproximação à concretude do ser social, oportunizada pela captação do processo de reprodução em seu conjunto. Isso ocorre na teoria da taxa de lucro, conforme a qual valor e mais-valor permanecem sendo as categorias ontológicas fundamentais do setor econômico capitalista. Lukács (2012, p. 326-327) diz como isso está colocado nos livros de $O$ capital:

\begin{abstract}
No nível de abstração do Livro I, basta a constatação de que só a peculiaridade da mercadoria "força de trabalho" é capaz de criar valor novo, enquanto os meios de produção, a matéria-prima etc simplesmente conservam o seu valor no processo de trabalho. A concretização do Livro II fornece a análise do processo global que, em muitos aspectos, ainda se mantém sobre essa base; isso ocorre na medida em que, como elementos do ciclo, figuram o capital constante e o capital variável, assim como o mais-valor. Aqui resulta verdadeiro que, na totalidade do processo considerado em sua generalidade pura, ou seja, prescindindo com consciência metodológica dos atos singulares que o formam na realidade -, a lei do valor continua em vigor sem alterações. E trata-se mais uma vez de uma constatação correta e importante no plano ontológico, pois os desvios da lei do valor necessariamente se compensam na totalidade do processo. Reduzido a uma formulação simples: é impossível que o consumo (inclusive o consumo produtivo da sociedade) seja maior que a produção.

De qualquer modo, o problema do Livro III é o seguinte: no interior do ciclo total, agora compreendido, investigar as legalidades que regulam os atos econômicos singulares, e não apenas para si, mas precisamente no quadro da compreensão da totalidade do processo. (Grifos meus)
\end{abstract}

Todavia, a capacidade de alterar ontologicamente as categorias pela influência dos atos singulares sobre o processo global tem duas premissas histórico-reais: "em primeiro lugar, o crescimento das forças produtivas com seus efeitos de rebaixamento do valor; em segundo, a ampla possibilidade que tem o capital de migrar de um ramo para outro" (LUKÁCS, 2012, p. 327). Os dois processos exigem, em suas ocasiões, uma condição relativamente superior de desenvolvimento social, o que demonstra novamente que as categorias econômicas demandam uma existência evoluída na operacionalização do ser social. Ou seja, as categorias econômicas são explicitadas como resultado do desenvolvimento histórico-social com o advento da superação categorial das barreiras do mundo da natureza (LUKÁCS, 2012).

Não sendo uma lei mecânica que interdepende da atividade econômica dos homens ou um produto conduzido por essa atividade, a lei da taxa de lucro é uma categoria econômica determinante. No Livro III, está posta a decorrência metodológica de superação das abstrações ordenadas, no Livro I, na transformação do mais-valor em lucro, da taxa de mais- 
valor em taxa de lucro 22 . Apesar de ser uma outra relação, esta entre "mais-valor" e "lucro", a dependência da relação originária é predominante, já que o mais-valor se mantém ainda como base real (LUKÁCS, 2012).

Como não há o interesse de perpassar como Marx exibe o aspecto tendencial dessa nova lei, importa para Lukács (2012) fazer dois destaques nos quais existem pontuações para se pensar os marcos de efetividade do caráter tendencial de uma lei em função da mobilidade operante entre os complexos reais e a exemplificação pela taxa de lucro. Assim, os atos singulares podem ter desdobramentos imprevisíveis e, por vezes, contrários à subjetividade de determinada ação teleológica.

(...) primeiro, que a tendencialidade, enquanto forma fenomênica necessária de uma
lei na totalidade concreta do ser social, é consequência inevitável do fato de que nos
encontramos diante de complexos reais que interagem de modo complexo,
frequentemente passando por amplas mediações com outros complexos reais; a lei
tem caráter tendencial porque, por sua própria essência, é resultado desse
movimento dinâmico-contraditório entre complexos. Segundo: que a taxa de lucro,
em sua queda tendencial, é o resultado final de atos teleológicos individuais, ou seja,
de pores conscientes, mas seu conteúdo, sua direção etc. produzem o exato oposto
do que era visado objetiva e subjetivamente por esses atos individuais. Esse fato
fundamental, elementar e necessário, da existência e das atividades histórico-sociais
dos homens se apresenta, também nesse caso, sob uma forma factual que pode ser
verificada de modo exato; quando as relações econômicas são compreendidas em
sua totalidade dinâmica e concreta, torna-se evidente, a cada passo, que os homens
fazem sua própria história, mas os resultados do decurso histórico são diversos e
frequentemente opostos aos objetivos visados pelos inelimináveis atos de vontade
dos indivíduos humanos. É preciso acrescentar, além disso, que, no âmbito do
movimento total, entra em cena o progresso objetivo. A queda da taxa de lucro
pressupõe a modificação do valor dos produtos por causa da diminuição do tempo
de trabalho socialmente necessário para produzi-los. (Ibidem, p. 328-329; Grifos
meus)

Isso se justifica no fato do crescente domínio do homem sobre as forças naturais, aumentando sua competência produtiva e reduzindo o tempo de trabalho socialmente necessário para se produzir (LUKÁCS, 2012).

\footnotetext{
${ }^{22}$ Em Lukács (2012, p. 328), essas transformações são explicadas no seguinte trecho: "Enquanto o mais-valor é relacionado apenas com o valor da força de trabalho e, em consequência, com o capital variável que a põe em movimento em sentido capitalista, o lucro, que imediatamente, mas só imediatamente, é idêntico ao mais-valor em termos qualitativos, é relacionado também com o capital constante. Os atos singulares que realizam a produção, o consumo etc orientam-se assim, em primeiro lugar, no sentido de aumentar o lucro. Ora, o desenvolvimento das forças produtivas, que necessariamente se manifesta primeiro em pontos singulares, provoca em tais pontos a emergência de um extraprofit [superlucro], que naturalmente se torna a finalidade dos atos teleológicos dos produtores singulares; dada a diminuição assim obtida do valor dos produtos, a mercadoria pode ser vendida acima do seu valor e, ao mesmo tempo, a um preço mais baixo do que aquela dos demais produtores. Só num estágio de desenvolvimento que permita a migração - relativamente - arbitrária do capital de um ramo para outro é que tal situação pode não conduzir a um monopólio duradouro. Nesse estágio, ao contrário, ocorre um rebaixamento do preço ao nível da máxima diminuição de valor provocada pelo aumento da produtividade. Assim, por um lado, essa possibilidade de migração do capital impõe uma taxa média de lucro e, por outro, no movimento deste último verifica-se uma tendência à queda contínua, precisamente por causa do crescimento das forças produtivas".
} 
Além disso, o Livro III trata de outros complexos, iluminando abstrações antecedentes e abancando complexos concretos, como a repartição social do mais-valor convertido em lucro, na qual a conversão do mais-valor em lucro predispõe que ele seja distribuído entre todos os sujeitos economicamente necessários à divisão social do trabalho, trazendo vastas e pormenorizadas digressões históricas de complexos econômicos que surgem nele como novos elementos (LUKÁCS, 2012).

Dito isso, Lukács (2012) retorna para a análise categorial da Introdução ao "Rascunho", cuja atenção volta-se para a complexidade e a dinâmica das estruturas e conexões categoriais que possibilitam o entendimento do autêntico método de Marx através da apreciação das categorias mais gerais e fundamentais da economia: produção, consumo, distribuição, troca e circulação ${ }^{23}$. Estas são elementos mediativos para o alcance dos conceitos da prioridade ontológica e do momento predominante no domínio de interações complexas em que se analisa, em primeira instância, a produção material.

Dessas discussões em diante, os passos consecutivos de Lukács é debater uma das dimensões mais decisivas da ontologia marxiana. Trata-se da historicidade do ser social em sua totalidade, no complexo de suas partes, de suas conexões mútuas, de suas mudanças resultantes das alterações do todo e dos complexos que o constituem. Como alguns pontos são tratados no primeiro capítulo, as considerações acerca da historicidade do ser social são apenas no sentido de ressaltar certas questões mais fundamentais.

Lukács (1978) argumenta que Marx extrai as consequências do desenvolvimento histórico, verificando, por suas descobertas, que os homens se autocriam através do trabalho. A autêntica história do ser social só pode começar com a instauração do comunismo, pois o que os homens viveram até agora é a pré-história da humanidade. Para Marx, o comunismo é o estado real de sociabilidade no qual há a explicitação das forças genuinamente humanas proporcionadas pelo desenvolvimento alcançado em níveis superiores na condição de importantes realizações humanas, obra da atividade dos próprios homens. A história é feita, então, na medida em que os homens são seres que emitem respostas às circunstâncias que envolvem seu mundo. Tem-se, pois, a expressão, contida contraditoriamente no ser social, da unidade entre a liberdade e a necessidade. Uma unidade reproduzida incessantemente sob novas formas, mais complexas e mediatizadas, em todas as ordens de individualidade e sociabilidade da atividade humana. É em função disso que Marx fala da verdadeira história como um "reino de liberdade", o qual, contudo, só pode acontecer tendo a base do "reino da

\footnotetext{
${ }^{23}$ Para maiores esclarecimentos, ver Marx (2015).
} 
necessidade" compreendido na reprodução socioeconômica e nas tendências objetivas de desenvolvimento.

Lukács (1978) aborda o reino da liberdade concebendo-o da seguinte maneira:

\begin{abstract}
É o produto da própria atividade humana, que decerto sempre atinge concretamente alguma coisa diferente daquilo que se propusera, mas que nas suas consequências dilata - objetivamente e de modo contínuo - o espaço no qual a liberdade se torna possível; e tal dilatação ocorre, precisamente, de modo direto, no processo de desenvolvimento econômico, no qual, por um lado, acresce-se o número, o alcance etc., das decisões humanas entre alternativas, e, por outro, eleva-se ao mesmo tempo a capacidade dos homens, na medida em que se elevam as tarefas a eles colocadas por sua própria atividade. Tudo isso, naturalmente, permanece ainda no "reino da necessidade". (LUKÁCS, 1978, p. 17)
\end{abstract}

É justamente na interligação entre o reino da liberdade e o reino econômico da necessidade que se manifesta como a liberdade do gênero humano é resultado da atividade do ser social. A liberdade que é posta como uma decorrência no plano do ser assume um sentido ontológico perante o processo de desenvolvimento da "base sociomaterial".

Para Lukács (1978), o surgimento e a explicitação da personalidade humana são uma outra consequência indireta do desenvolvimento do processo de trabalho. Ela se apoia na elevação das capacidades, mas não chega a ser um simples e unidimensional desdobramento. Existe uma assídua relação de oposição que se enraíza com o processar de um desenvolvimento cada vez mais elevado. Nos dias atuais, o desenvolvimento das capacidades, com uma gama maior de diferenciações, atravanca o devir da personalidade, como uma via de alienação da personalidade do homem. Contrariamente, com o trabalho mais primitivo, modifica-se a situação "muda" da adequação dos homens ao gênero. De modo principiante e imediato, porém, essa adequação se torna apenas um ser-em-si. "Por maiores que sejam os progressos da socialidade, por mais que seu horizonte se alargue, a consciência geral do gênero humano não supera ainda essa particularidade da condição do indivíduo e do gênero dada em cada oportunidade concreta" (LUKÁCS, 1978, p. 18). Isto é, há uma restrição à objetividade histórica concreta do estado da consciência ativa de determinado contexto social, economicamente fundado, o que acaba sendo determinante no ser-para-si dos indivíduos.

Por outro lado, a elevação da adequação ao gênero ainda é uma prioridade no devirhumano. Pela definição de Marx, o reino da liberdade, "um desenvolvimento de energia humana que é fim em si mesmo", está passível para o homem individual e a sociedade por suas disposições na transformação dele como um fim autônomo. Todavia, para que isso aconteça, para a adequação ao gênero, é preciso um nível de reino da necessidade que não foi alcançado. 
Só quando o trabalho for efetiva e completamente dominado pela humanidade e, portanto, só quando ele tiver em si a possibilidade de ser "não apenas meio de vida", mas "o primeiro carecimento da vida", só quando a humanidade tiver superado qualquer caráter coercitivo em sua própria autoprodução, só então terá sido aberto o caminho social da atividade humana como fim autônomo. (LUKÁCS, 1987, p. 18)

A consciência em torno do trabalho como "o primeiro carecimento da vida" é a percepção de todo caráter formativo que reside nele, possibilitando que os homens sejam tudo aquilo que eles têm o potencial de ser. Isso, para Lukács (1978, p. 18), significa “(...) criar as condições materiais necessárias e um campo de possibilidades para o livre emprego de si”. Tais aspectos são oriundos da atividade humana, tanto no que se refere ao produto de um desenvolvimento necessário quanto ao uso correto, humano, do que foi produzido necessariamente. Assim, “A própria liberdade não pode ser simplesmente um produto necessário de um desenvolvimento inelutável, ainda que todas as premissas de sua explicitação encontrem nesse desenvolvimento - e somente nele - suas possibilidades de existência" (Ibidem, p. 18). Entretanto, todas as possibilidades reais de realização são produzidas por um processo necessário. $\mathrm{O}$ ser social deve conquistar sua própria liberdade por meio de seu desempenho. Isso só é possível porque em toda sua atividade já reserva uma zona de liberdade, cuja referência se faz na decisão entre alternativas. 


\section{CAPÍTULO III - ONTOLOGIA E EDUCAÇÃO: ACERCA DA PEDAGOGIA HISTÓRICO-CRÍTICA}

Este capítulo tem a intenção de se arriscar no sentido da Pedagogia Histórico-Crítica, pedagogia $^{24}$ socialista de inspiração marxista, situando o lugar e o alcance de seus pressupostos filosóficos, seu significado político e algumas nuances de seu modelo pedagógico-metodológico. Esses aspectos estão intimamente veiculados a determinado projeto social revolucionário, que implica a mobilização coletiva para as transformações sociais radicais com interesse de causa da classe trabalhadora.

Não é uma exposição exaustiva, mas colocações que convergem para as especificações nas quais se assenta essa pedagogia na articulação da educação e do estatuto ontológico do ser social para, posteriormente, olhar o contexto dos processos formativos do mundo da Educação Física, também nessa lógica articuladora, no próximo capitulo.

A Pedagogia Histórico-Crítica é uma corrente teórica ${ }^{25}$ ainda em processo de formulação com esforços conjuntos de desenvolvimento e aprofundamento. Isto a fim de trazer novos subsídios que ampliem e reforcem a consistência e a efetividade de sua proposta educativa, sendo também empenhos importantes no combate às críticas e ofensivas contra ela.

Essa pedagogia aparece como uma resposta histórica ao movimento educacional de oposição à pedagogia liberal burguesa. Esta acaba por englobar outras pedagogias, que, mesmo não estando ligadas diretamente, reproduzem o status quo capitalista pela falta de uma posição política clara ou de ações propositivas divergentes à ideologia dominante.

\footnotetext{
${ }^{24}$ É interessante trazer a perspectiva do que seja a denominação pedagogia. Em Saviani (2005), é possível encontrar uma compreensão bastante notória quando ele a trata como uma abordagem de "teoria da educação". Evidencia-se que se discursa sobre uma teoria da prática: a teoria da prática educativa. "Na verdade o conceito de pedagogia se reporta a uma teoria que se estrutura a partir e em função da prática educativa. A pedagogia, como teoria da educação, busca equacionar, de alguma maneira, o problema da relação educador-educando, de modo geral, ou, no caso particular da escola, a relação professor-aluno, orientando o processo de ensino e aprendizagem" (Ibidem, p. 1).

${ }^{25}$ A título de enriquecer mais o debate, é pertinente pontuar um adendo de Saviani (2005). Ele ainda afirma que, do ponto de vista da pedagogia, as diferentes concepções de educação, nas correntes teóricas, podem ser agrupadas em duas grandes disposições: 1) composta pelas concepções pedagógicas que dariam prioridade à teoria sobre a prática, subordinando esta àquela, sendo que, no limite, dissolveriam a prática na teoria; modalidades de pedagogia tradicional; "teorias do ensino"; o problema fundamental se traduzia pela pergunta "como ensinar", cuja resposta consistia na tentativa de se formular métodos de ensino; nos séculos XVII, XVIII e XIX, a ênfase das proposições educacionais se dirigia aos métodos de ensino formulados a partir de fundamentos filosóficos e didáticos; 2) compõe-se das concepções que subordinam a teoria à prática e, no limite, dissolvem a teoria na prática; modalidades de pedagogia nova; "teorias da aprendizagem"; o problema fundamental se traduz pela pergunta "como aprender", o que levou à generalização do lema "aprender a aprender"/ "teorias da aprendizagem"; Escola Nova; no século XX, a ênfase se desloca para os métodos de aprendizagem, estabelecendo o primado dos fundamentos psicológicos da educação.
} 
Por um viés pedagógico de análise crítica, essa pedagogia se preocupa com a intervenção desempenhada pela escola. Esta é instância social por excelência responsável pela prática educativa deliberada e sistemática, proporcionando o acesso ao saber objetivo científico $^{26}$ para os indivíduos singulares no processo de democratização. Em outras palavras, ela concretiza determinado tipo de formação humana direcionado pelo trabalho educativo, a partir de determinadas acepções de mundo, homem, sociedade e educação.

Conforme Saviani (2013), a educação é um fenômeno verdadeiramente humano e próprio da exigência do e para o processo de trabalho. A noção da natureza desse fenômeno perpassa as linhas circundantes da natureza humana, que só se explica por meio da materialização do trabalho. Como dito anteriormente, o trabalho é a atividade propositada na qual o homem produz sua existência, garantindo o suprimento das necessidades basais de sobrevivência, ao agir na natureza e criar um mundo da cultura como desdobramento da produção de bens materiais. Este é o trabalho material. Contudo, há outro modelo de produção que pode ser traduzido no trabalho não material, que se refere ao movimento de se produzir ideias, conceitos, valores, símbolos, hábitos, atitudes, habilidades, conhecimentos acerca das propriedades do mundo real (ciência), de valorização (ética) e de simbolização (arte), ou seja, dos saberes da natureza e da cultura. Entre as duas modalidades de trabalho não material: 1) atividades nas quais reside uma autonomia entre o produto $\mathrm{e} o$ ato de produção com a separação do produto em relação ao produtor por um intervalo entre a produção e o consumo; 2) atividades que não admitem uma dissociação do produto com o ato de produção, pois a produção e o consumo são momentos simultâneos ${ }^{27}$, é nesta que a educação está inclusa.

Diferente de outros animais que são capazes de se adaptar à realidade natural para reproduzir sua existência, o homem precisa produzir suas condições de vida. Porém, permanece à disposição na natureza humana de superar a produção restrita aos meios de sua subsistência, o que está preponderantemente imbricado na criação de novas necessidades propriamente sociais ao passo do desenvolvimento da sociabilidade. Isso se confirma no fato de o mundo dos homens ser um complexo de complexos. Uma totalidade social organizada por distintos processos que, de uma forma ou de outra, estão envolvidos com autonomia e interdependência relativas. Para a satisfação das necessidades dadas e criadas e a crescente

\footnotetext{
${ }^{26}$ São vários os tipos de saber ou de conhecimento construídos pelos homens: conhecimento sensível, intuitivo, afetivo, intelectual, lógico, racional, artístico, estético, axiológico, religioso, prático e teórico, todavia aquele que interessa estar disponível na escola é o saber produzido historicamente de maneira sistematizada que emerge como resultado do processo de ensino-aprendizagem, do trabalho educativo (SAVIANI, 2013).

${ }^{27}$ Saviani (2013) exemplifica isso comentando o ato de ensino. Na materialização de uma aula, sua produção e seu consumo acontecem ao mesmo tempo: produzida pelo professor e consumida pelos alunos.
} 
complexificação dos atos sociais são colocadas mediações sociais cada vez mais numerosas, diversificadas e complexas como algo indispensável para a continuidade da reprodução social. Há, pois, com a processualidade histórica, a generalização subjetiva e objetiva dos resultados da práxis, autenticando a concreta construção da generalidade humana em-si e para-si pelo patamar de desenvolvimento sociogenérico da humanidade. E é nesse âmbito que a educação se funda como um complexo do ser social, sendo uma mediação posta na especificidade da esfera do ser social: os homens se formam entre si. Participante do conjunto de posições teleológicas secundárias, a educação é um complexo que está decisivamente consubstanciado pela incorporação dos elementos do gênero humano e pela apropriação das determinações do real para poder operar posições teleológicas. Longe de ser uma simples inculcação subjetiva, o ato educativo é validado no atendimento de uma insuficiência do homem: de submeter os indivíduos singulares ao processo de adequação ao gênero humano. É fundamental educar os homens e formar sua consciência.

O eixo de particularidade da educação se elucida, assim, na assimilação dessa totalidade da produção humana como uma segunda natureza. São meios necessários à constituição da humanidade em cada indivíduo que é produzida através de relações pedagógicas fundadas entre os homens e determinadas pelas fases sócio-históricas (SAVIANI, 2013).

Então, a razão de ser da escola sucede de demandas causadas por sociabilidades mais amplas e evoluídas, sendo imperativo instituir o pedagógico. A educação escolarizada passou a ser a configuração prioritária de práticas educativas pelo processo de escolarização em que se encontra a dimensão pedagógica existente no interior da prática social global (SAVIANI, 2013).

Por essas considerações, a Pedagogia Histórico-Crítica comprova seu diferencial. Ela faz uso do reconhecimento da referência à materialidade, no caso, da ação pedagógica, quando tem como ponto de partida o entendimento de que o conhecimento é parte efetiva da estrutura produtiva. São determinantes, portanto, as mudanças operadas pela sucessão dos modos de produção que, ao longo da história social, foram suscitando diferentes processos educativos e contradições próprias de cada um deles. Essa observação analítica culmina na relação do modo de produção capitalista e sua manipulação, sobretudo da educação formal ${ }^{28}$ a

\footnotetext{
${ }^{28}$ Neste trecho, Saviani e Duarte (2012) detalham a realidade da escola na ordem burguesa como uma das possibilidades direcionais que o movimento das contradições pode nortear: “(...) consiste em ações que - desde o plano da política educacional até o trabalho em sala de aula, passando pelo da difusão de pedagogias que postulam para a escola quase todas as funções, menos a de transmissão sistemática de conhecimento - entravam de todas as formas possíveis a constituição de um sistema nacional de educação pública que permita às crianças,
} 
favor de sua reprodução com práticas educativas esvaziadas e precarizadas. Burgueses e trabalhadores não são educados da mesma forma, porque a estes últimos está reservada a formação especializada profissionalizante de preparação para o mercado de trabalho com valores como a empregabilidade. Marcha-se para o inverso: estágios mais acentuados do grau de alienação dos indivíduos e a perda de si mesmos para um poder que lhes é estranhado. A sujeição das práticas educativas, em consonância com a infraestrutura social, tem influência decisiva na formação humana e da consciência para-si do ser social, e na maneira como os homens usufruem das riquezas espiritual e material universais.

A Pedagogia Histórico-Crítica atua pela valorização dos fundamentos ontológicos dos homens constituídos na condição de indivíduos reais para refletir sobre uma formação pautada na emancipação humana e na transformação da base social. Em Saviani e Duarte (2012), o argumento é o de que os fatores moventes da revolução dependem da aquisição daquilo de mais elaborado no patrimônio cultural da humanidade, como instrumento intelectual altamente desenvolvido para o desvelamento das determinações sócio-históricas das condições objetivas reais. Com a finalidade de transformar conscientemente a realidade social, é preponderante compreendê-la para além do que se apresenta como mais imediato. "Pensar a realidade usando as abstrações teóricas não é uma capacidade que se forme espontaneamente, é algo que precisa ser produzido deliberadamente pela escola" (Ibidem, p. 4). A revolução transcorre significantemente nas salas de aula. Tem-se, então, que "No processo revolucionário dá-se um salto na forma de organização da sociedade, mas justamente o que possibilita essa grande transformação é o domínio consciente das condições e contradições que se formaram na realidade anterior" (Ibidem, p. 4). Por outro lado, essa atividade, como um processo a nível de consciência, é incapaz de revolucionar isoladamente. Não basta somente conhecer, a sustentação vem dos comportamentos materiais, da realização de ações transformadoras que radicalizam o processo revolucionário. Por isso, a Pedagogia

adolescentes e jovens da classe trabalhadora o acesso ao saber erudito. O sistema escolar estrutura-se de forma fragmentada, reproduzindo a divisão social do trabalho e a lógica do mercado. O acesso ao conhecimento dá-se de maneira profundamente desigual e seletiva. Tudo isso, entretanto, é camuflado pelo discurso de respeito às diferenças culturais, pelo fetichismo da democratização do acesso ao conhecimento, espontaneamente assegurada pelas tecnologias de informação e pela subordinação dos objetivos da educação escolar a uma lógica de permanente esforço do indivíduo para se adaptar às mudanças constantes das condições de vida e de trabalho, normalmente no sentido de precarização. Preconiza-se, como ambiente próprio a uma escola dinâmica e adequada ao século XXI, a reprodução da dispersão em diversas atividades simultâneas que só se podem realizar de forma superficial e imediatista. Concentração, esforço intelectual e abstração para aproximar os alunos dos clássicos do conhecimento são coisas tidas como pertencentes a um passado inapelavelmente superado. Enquanto isso, são realizados debates e mais debates tentando entender as causas do chamado "bullying" e também se generaliza o uso de medicamentos para a solução de supostos transtornos ou distúrbios psiconeurológicos e multiplicam-se as clínicas para tratamento de supostos problemas de aprendizagem. Pelo lado dos professores, o adoecimento torna-se quase que um aspecto inerente ao exercício da profissão". (Ibidem, p. 2-3; Grifos meus) 
Histórico-Crítica defende a reestruturação produtiva pela socialização tanto do conhecimento em suas formas mais desenvolvidas quanto da propriedade dos meios de produção.

Duarte (2011) acrescenta que, na Pedagogia Histórico-Crítica, a educação contemporânea tem o direcionamento da formação do ser humano na sociedade comunista. Isso sugestiona, para quem possa se alinhar a essa pedagogia, uma posição nítida perante a luta de classes na contraposição entre o capitalismo e o comunismo. Contrariando os mais céticos, considerar uma sociabilidade comunista é uma possibilidade concreta dada pelo movimento do real existente e pelas experiências históricas anteriores reguladas pelo anacronismo entre o desenvolvimento das forças produtivas e as relações sociais de produção da conjuntura vigente com o motor propulsor das lutas de classes.

\subsection{Contextualização histórica da Pedagogia Histórico-Crítica}

Tratar da origem histórica da Pedagogia Histórico-Crítica tangencia dois pontos: o advento de um movimento pedagógico, formado em 1970, visando encontrar novos rumos alternativos à pedagogia dominante; e a definição da sua nomenclatura.

Saviani (2013) aponta que, nos anos 70, foi central o desenvolvimento de análises críticas da educação como uma missão imediata, tanto no cenário mundial quanto no Brasil, onde se percebeu o status reprodutor da pedagogia oficial. O decorrer dos anos 60 e 70 mostrou que essa movimentação teve escala global e que as teorias formadas nesse período correspondiam à tentativa de se entender o fracasso do movimento de maio de 1968 e, mais amplamente, os movimentos da década de 60, caracterizados pela rebelião dos jovens para os quais vários intelectuais designaram o protagonismo revolucionário tirando-o do proletariado. Nessa conjunção, a educação institucionalizada foi a mais questionada e fragilizada. Principalmente em 1968, esse movimento assumiu atributos de rebelião social que, por meio da revolução cultural, poderia pleitear modificações nas bases da sociedade, a partir da juventude, encabeçada pelos estudantes universitários.

Dada a expectativa de revolução social, ideologias esquerdistas tiveram grande repercussão no movimento, entre elas o marxismo e outras versões avessas a ele. Houve uma significativa influência do maoísmo, variação da ideologia marxista na China, que se apresentou antagônica à versão russa, cuja imagem estava associada ao stalinismo e aos desmandos autoritários e criminosos de Stalin. Por causa disso, o norte das observações analíticas foi a experiência chinesa, já que os intelectuais da esquerda repulsaram a orientação russa (SAVIANI, 2013). 
Como a mobilização teve o desfecho do fracasso do movimento de 68, muitos teóricos da época se dedicaram a entender os motivos que o levaram ao insucesso. Para Saviani (2013), as teorias crítico-reprodutivistas são desdobramentos dessa dedicação, tendo em vista que a intenção política de revolucionar a organização social através da cultura e, dentro dela, da educação, não era viável. A ambiência cultural não possui potencialidade material para alterar a sociedade, pois são as relações sociais que determinam a superestrutura.

Saviani (2013) destaca alguns pensadores e trabalhos que abordaram a questão da reprodução da ideologia e das relações de dominação burguesa. E inicialmente é citado Althusser, autor do artigo Ideologia e aparelhos ideológicos do Estado, publicado em 1970, no qual “(...) se evidencia a determinação material da ideologia e se distinguem os aparelhos ideológicos dos aparelhos repressivos de Estado, cumprindo, ambos, as funções de cimentar as relações de força e reproduzir as condições sociais dominantes" (SAVIANI, 2013, p.112). Outra teoria mais acabada e sistemática é divulgada em 1970, que passou a ser conhecida como a teoria da violência simbólica e é explanada no livro A reprodução. Saviani (2013) traz sua preferência pela denominação teoria do sistema de ensino como violência simbólica, porque a teoria abordada no livro perpassa um tipo de violência simbólica própria desse sistema no desempenho de sua função de reproduzir a "cultura arbitrária dos grupos ou classes dominantes". No outro extremo, a teoria da violência simbólica, na verdade, atua como uma prerrogativa e está compendiada no enunciado "axioma zero”, “(...) cujo conteúdo evidencia que a cultura é violência simbólica na medida em que reproduz, legitimando e reforçando, por dissimulação, as relações de força que lhe servem como base" (SAVIANI, 2013, p.113). É o ponto inicial para falar e organizar teorias sobre qualquer uma das dimensões da cultura.

Em 1971, na obra A escola capitalista na França, Baudelot e Establet caminharam no mesmo sentido de confirmar a escola como um espaço/tempo que funciona na condição de extensão dos ideais e das relações do modo de produção capitalista para os burgueses e o operariado, isto é, a educação escolar como parte da totalidade capitalista, constituindo-se num processo contraditório de humanização e alienação. Diferente de Bourdieu e Passeron, que seguem o pensamento de Weber coligado a Durkheim, apesar de reconhecerem as contribuições de Marx, Baudelot e Establet estão inseridos no cerne do marxismo e suas formações aconteceram sob luz de Althusser e, em seguida, romperam com ele e se ligaram ao maoísmo. Eles se preocuparam em fazer um trabalho pautado na teoria da contradição e o 
resultado da análise feita por eles, com o pilar da teoria marxista, é mais uma crítica incisiva ao fator reprodutivista do aparelho educacional.

\footnotetext{
Mantêm a ideia de Althusser de que a escola é um aparelho ideológico de Estado e tentam mostrar a sua função. Procuram explicitar aquilo que em Althusser aparecia apenas como uma ideia diretriz, e farão isso a partir de uma análise detalhada dos dados estatísticos relativos ao sistema de ensino francês. (SAVIANI, 2013, p. 113)
}

Alcançaram o entendimento de que o sistema de ensino se constitui pelas redes SS (secundária-superior) e PP (primária-profissional), as quais se correlacionam ao ensejo de inculcação ideológica e a reprodução das relações sociais do setor produtivo.

Essa compreensão teórica reafirma um componente que já estava presente no movimento de maio de 68 , todavia, de modo comprometedor das possíveis saídas no âmbito pedagógico. Nos anos 60, toda a crítica à burocracia e às instituições, entre elas, a escola, estava cunhada na superação desses obstáculos em que se nota, no movimento de 68, a pedagogia institucional, crítica da escola para se pensar a "instauração de relações igualitárias". É por essa via que se converteu a realização da revolução social por meio da revolução cultural. Diante da falha dessa teoria, outras novas concluíram que, de fato, o fracasso era iminente, já que a premissa é a de que, entre as bases sociais e a cultura, a relação de determinação parte da primeira para a segunda (SAVIANI, 2013).

No Brasil, a assimilação dessas teorias aconteceu rapidamente à medida que elas foram construídas e disseminadas, circulando entre os cursos de pós-graduação brasileiros. Através delas, as forças de resistência ao regime militar foram sendo fomentadas e funcionaram como ferramentas de condenação da política educacional do regime, “(...) que era uma política de ajustamento dos aparelhos ideológicos do Estado utilizados como instrumentos de controle da sociedade, visando a perpetuar as relações de dominação vigentes" (SAVIANI, 2013, p. 114).

A situação político-econômica no país motivou mudanças nesse contexto, visto que o Brasil entrava no período político chamado de "abertura e transição democrática". As limitações das teorias crítico-reprodutivistas ficaram evidentes e se instalou um quadro de dúvida perante qual orientação alternativa seria apropriada, visto que a pedagogia oficial não era admissível. A perspectiva crítico-reprodutivista não dava conta de responder essa dúvida, pois ela não apresentava uma proposta direta de intervenção para a prática educativa, limitando-se apenas em criticar a realidade, colocando-a como susceptível a função de reprodutora e a exercia. "Essa crítica foi mais longe com a formulação mais acabada de 
Bourdieu e Passeron, que deixaram claro que toda proposta pedagógica, qualquer que ela seja, sempre desempenhará esse papel, quer os agentes tenham ou não consciência disso" (SAVIANI, 2013, p. 114). Por essa análise, não existiria saídas no âmbito educacional. Entretanto, houve uma intensificação pelo movimento de educadores na tarefa de colocar opções a esta problemática, discutindo as teorias a fim de encontrar os déficits e a superação delas. Importante ressaltar que esta crítica já vinha sendo feita na França, país de origem dessas teorias, através dos trabalhos de Vicent Petit, Les contradictions de 'La réproduction', e Georges Snyders, École, classe et lutte de classes.

Destarte, dadas as situações existentes, Duarte (1993 apud DELLA FONTE, 2011) identificou duas polêmicas que se instalaram no cenário educacional brasileiro. Uma delas está ligada à tecnologia educacional e seus pressupostos positivistas (início dos anos de 1970) e a outra é esta situação com as teorias crítico-reprodutivistas (final dos anos de 1970 e começo da década de 1980). Por essa notificação, o autor assevera a importação de proclamar o caráter político da educação e sua colocação na luta contra-hegemônica.

Saviani $(2011 ; 2013)$ afirma que um fato excepcional, nos anos finais de 70 , foi a ocorrência numa diligência coletiva de organizar o setor educacional com a criação de entidades, como a Associação Nacional de Pesquisa e Pós-Graduação em Educação (ANPED), de 1977; Centro de Estudos Educação e Sociedade (CEDES), envolvido com a coordenação do Primeiro Seminário de Educação Brasileira, de 1979; e Associação Nacional de Educação (ANDE), de 1979. Tais entidades se juntaram com o intento de preparar uma série de conferências brasileiras de educação.

Em 1980, foi realizada a primeira CBE, cujo tema mais proeminente foi a busca de alternativas para a situação política do país, entre outras questões abordadas em associação. A aversão ao Regime Militar já havia alcançado algumas prefeituras que implantaram outras políticas educacionais, caso de Lajes e Piracicaba. Foram restabelecidas as eleições diretas para governadores e encetadas as campanhas para 1982. A probabilidade e a oportunidade de a oposição chegar ao poder eram abertas, trazendo junto a carência e a exigência real de uma política educacional que estivesse de acordo com o seu discurso (SAVIANI, 2013).

Saviani (2013) aponta que essa edição da CBE refletiu essas circunstâncias caóticas. A sua participação no simpósio Abordagem política do funcionamento interno da escola de primeiro grau gerou como fruto o texto Escola e Democracia ou Teoria da Curvatura da Vara, incluso no livro Escola e democracia. Nessa oportunidade, ele discorreu sobre o tema invertendo os termos usados em que a pedagogia tradicional e a pedagogia nova se objetavam no ponto de vista dos professores. Ele problematizou o consenso subjetivo dos professores 
com a visão de que a Escola Nova era inovadora. Ainda procurou polemizar utilizando o jogo de palavras revolucionária e reacionária e seus valores semânticos. No ano posterior, 1981, após outro seminário relativo à estrutura de ensino na universidade brasileira, na Universidade Federal de São Carlos, com a mesma lógica de pensamento, Saviani publicou mais um artigo, Escola e democracia II: para além da teoria da curvatura da vara, que se tornou o Capítulo III de seu livro Escola e democracia, no qual estavam esboçados os embasamentos elementares do que mais tarde seria denominada Pedagogia Histórico-Crítica. E, para manter o quadro polêmico gerado anteriormente, apareceu com o nome de Pedagogia Revolucionária.

A denominação histórico-crítica surgiu como consequência desses fatos e a exigência foi feita por parte de alunos da Pontifícia Universidade Católica de São Paulo (PUC - SP) de uma disciplina optativa que trabalhasse o estudo da pedagogia revolucionária. Isso fez com que Saviani repensasse o termo revolucionária, porque ele alude a alterações nas bases sociais, almejando encontrar uma nomeação mais pertinente. A primeira opção então foi pedagogia dialética.

De fato, o que se pretendia era uma proposta pedagógica que estivesse atenta aos determinantes sociais da educação e que permitisse articular o trabalho pedagógico com as relações sociais. Mas isso não se poderia dar de forma mecânica. Teria que ser em termos dialéticos, ou seja, teria que levar em conta a ação recíproca em que a educação, embora determinada, em suas relações com a sociedade reage ativamente sobre o elemento dominante, estabelecendo uma relação dialética. (SAVIANI, 2013, p. 117-118)

Contudo, Saviani considerou evitar a denominação pedagogia dialética diante dos fatores complicadores ${ }^{29}$ que poderiam deturpar o uso da palavra dialética.

Ao detectar nas concepções crítico-reprodutivistas a carência de um enraizamento histórico, embora lhes fosse intrínseca uma dimensão de criticidade, Saviani entendeu que a expressão histórico-crítica era mais adequada aos propósitos e às ações do projeto educacional estabelecido em sua teoria pedagógica. Foi assim que, em 1984, Saviani ministrou a disciplina "Pedagogia Histórico-Crítica" e passou a chamar assim a corrente pedagógica que está sendo construída (SAVIANI, 2013).

\footnotetext{
${ }^{29}$ Saviani (2013) fala a respeito de alguns elementos que embaraçavam a denominação pedagogia dialética: a ambiguidade do termo dialética e da expressão pedagogia dialética, que necessariamente estava ligada à concepção idealista de Hegel, mas há também várias outras que penetram nas origens gregas; e, dentro da dimensão pedagógica, duas obras que datam de 1983: Pedagogia dialética, de Schmied-Kowarzik, e Concepção dialética da educação, de Moacir Gadotti.
} 
De maneira geral, a Pedagogia Histórico-Crítica surge como uma possibilidade plausível para a necessidade diagnosticada pelos educadores brasileiros de superar tanto as pedagogias não críticas (concepção tradicional, escolanovista e tecnicista) quanto as visões do crítico-reprodutivismo (teoria da escola como aparelho ideológico do Estado, teoria da reprodução e teoria da escola dualista).

Savianni (2013, p. XVI-XX; prefácios) diz que, na década de 80, essa proposta pedagógica alcançou uma expressiva propagação, tendo até mesmo uma experimentação de sua implantação em alguns sistemas de ensino oficiais. Em 1990, em função da chegada ao aparelho governamental de governos considerados neoliberais, houve a promoção em vários países de reformas educacionais caracterizadas pelo neoconservadorismo. O nível de aderência à Pedagogia Histórico-Crítica foi reflexo do fluxo dos movimentos progressistas. Essa concepção pedagógica se manteve atuante ainda que no formato de resistência às implicações neoconservadoras com aparências de vanguarda. Passou a ser constante a declaração de que a educação é a chave para a resolução dos diferentes problemas sociais, a partir de sua função "redentora", numa suposição ingênua que ostenta alcances de nítida mistificação ideológica na qual há uma inversão: de elemento socialmente determinado, ela é convertida à determinação das relações sociais dotada da capacidade de modificá-las.

$\mathrm{Na}$ transição dos anos de 80 para os de 90, percebe-se um deslocamento no panorama característico da época em que se predomina o pensamento progressista nos debates pedagógicos com aderência ativa ao marxismo na área da educação. Saviani colocou sua concepção educacional explicitamente no terreno do materialismo histórico. Muitos do que aderiram ao "modismo marxista" passaram a se inserir na nova tendência alimentada pela ruína dos regimes do "socialismo real" e pelo advento do protagonismo do pensamento de direita, o "neoliberalismo". Tem-se a recomposição hegemônica do capitalismo com o prenúncio do fim da modernidade e o nascimento de uma nova era, a pós-moderna. Nessa atmosfera, o que está em voga é uma observância relativista e a negação da razão totalizadora da verdade e da objetividade, misto de irracionalismo e ceticismo, com traduções em "pósmodernidade", "transculturalidade", "complexidade", "lógica interativa e relacional", "pluralismo de perspectivas" etc. O que caracteriza, assim, o debate contemporâneo das teorias pedagógicas é a ideologia do movimento da pós-modernidade pela atuação da agenda pós-moderna em tempos de políticas neoliberais. Della Fonte (2011) relata que nesse cenário está presente um fenômeno de dupla interface na pesquisa educacional brasileira: a apatia das pedagogias críticas e a entrada do discurso pós-moderno na produção acadêmica da educação. 
Discurso este que age tanto contra o tecnicismo pedagógico e as teorias educacionais reprodutivistas como também contra as próprias teorias críticas da educação.

Nas duas últimas décadas, é Duarte (2001 apud DUARTE, 2010) quem aponta para o debate educacional caracterizado por uma quase total dominância das pedagogias do aprender a aprender. Aqui se destacam o construtivismo, a pedagogia do professor reflexivo, a pedagogia das competências, a pedagogia dos projetos, a pedagogia multiculturalista e o neoescolanovismo, este último segundo Saviani (DUARTE, 2010). Todas elas advêm de forma negativa dos modelos clássicos de educação escolar.

Consideráveis são as discussões que se fazem sobre elas, tanto no sentido de fortificálas por uma série de elementos como também de negar por um viés mais crítico os seus impactos incontestáveis. Assim, é pertinente pôr minimamente alguns aspectos acerca das pedagogias do aprender a aprender, assinalando ideias ou princípios comuns a elas que as confirmam em posições políticas e ideológicas conservadoras no compromisso com a lógica do capital. Elas denotam a articulação entre a prática educativa e os fundamentos ontológicos do ser social burguês, o ser econômico de espírito empreendedor. Duarte (2010) assinala cinco referências básicas que perpassam tais tendências pedagógicas: a ausência da perspectiva de superação da sociedade capitalista, que está associada a uma concepção idealista das relações entre educação e sociedade/ótica idealista de educação; negação do panorama de totalidade, ou seja, da afirmação do princípio de que a realidade humana seria constituída de fragmentos que se unem não por relações determinadas pela essência da totalidade social, mas sim por acontecimentos casuais, fortuitos e inacessíveis ao conhecimento racional; dessa negação da totalidade decorre um dos princípios centrais das pedagogias contemporâneas, o relativismo: em primeiro lugar, trata-se de um relativismo epistemológico e, em segundo lugar, o relativismo cultural; o cotidiano do aluno deve ser a referência central para as atividades escolares, ou melhor, são considerados conteúdos centrais e relevantes para o aluno aqueles que tenham alguma utilidade prática em seu cotidiano; soma-se a esse utilitarismo o princípio epistemológico pragmatista de que o conhecimento tem valor quando pode ser empregado para a resolução de problemas da prática cotidiana adjunto à supervalorização do conhecimento tácito, isto é, um conhecimento pessoal, não verbalizado e circunstancial.

Duarte (2008) faz considerações destacando ainda os posicionamentos valorativos intrínsecos aos ideários pedagógicos do lema aprender a aprender, desenvolvido na chamada sociedade do conhecimento, partindo de uma nova fase do capitalismo pautada em ilusões que concorrem para a reprodução ideológica da formação social capitalista contemporânea. 
Por aprender a aprender é preciso vislumbrar que “(...) trata-se de um lema que sintetiza uma concepção educacional voltada para a formação, nos indivíduos, da disposição para uma constante e infatigável adaptação à sociedade regida pelo capital" (DUARTE, 2008, p. 11). São quatro os seus posicionamentos: $1^{\circ}$ ) são mais convenientes as aprendizagens realizadas pelo próprio aluno de maneira autônoma, fomentando sua autonomia ao aprender a aprender, o que gera a eliminação do caráter social do ato educativo; $2^{\circ}$ ) o desenvolvimento por parte do aluno do seu método de conhecer (método de investigação), no qual o fato de ele ter condições de construir soluções por conta própria é mais importante do que os conhecimentos produzidos socialmente; $3^{\circ}$ ) é preciso que a atividade do aluno seja motivada e orientada pelos interesses e necessidades inerentes a ele; $4^{\circ}$ ) o papel da educação deve ser estabelecido no sentido da preparação do aluno para acompanhar a evolução da sociedade ao passo que, diante do dinamismo social e da provisoriedade do conhecimento, a ausência de atualização acarreta um anacronismo e um déficit de conhecimentos.

Atinente às ilusões, de acordo com Duarte (2008, p. 14), elas cumprem um posto privilegiado na sociedade do conhecimento que

\footnotetext{
(...) seria justamente a de enfraquecer as críticas radicais ao capitalismo e enfraquecer a luta por uma revolução que leve a uma superação radical do capitalismo, gerando a crença de que essa luta teria sido superada pela preocupação com outras questões "mais atuais", tais como a questão da ética na política e na vida cotidiana pela defesa dos direitos do cidadão e do consumidor, pela consciência ecológica, pelo respeito às diferenças sexuais, étnicas ou de qualquer natureza.
}

Ressaltam-se as seguintes ilusões: o conhecimento está cada vez mais acessível com sua democratização pelos meios de comunicação, pela informática, pela internet, etc; a importância da capacidade de mobilizar conhecimentos em relação à aquisição de conhecimentos teóricos, mormente, nos dias de hoje, em que estariam ultrapassadas as metanarrativas; o conhecimento é uma elaboração subjetiva resultante de processos semióticos intersubjetivos a partir de uma negociação de significados e são os contratos culturais que conferem validade a ele; não há uma hierarquia de qualidade ou da força explicativa da realidade natural ou social, pois os conhecimentos têm o mesmo teor valorativo; a existência de concepções idealistas de apelo à consciência dos indivíduos para a superação dos problemas da humanidade e a determinação desses problemas pela mentalidade humana.

Carregando os ranços desse contexto, ao penetrar no novo século, verifica-se a fragilidade das estruturas educacionais. Isso fica claro nas greves que ocorreram nesse período 
nas diferentes instâncias educacionais, desde o ensino superior até a educação básica. Está cada vez mais visível que são orgânicas e não apenas conjunturais as contradições postas pela formação social baseada na propriedade dos meios de produção. A resolução dos graves problemas educacionais só pode vir da transformação das relações sociais que os determinam. É preciso, consequentemente, recusar o discurso da força da educação como recurso solucionador dos males sociais.

\begin{abstract}
Ao contrário disso, faz-se necessário retomar o discurso crítico que se empenha em explicitar as relações entre a educação e seus condicionamentos sociais, evidenciando a determinação recíproca entre a prática social e a prática educativa, entendida, ela própria, como uma modalidade específica da prática social. E é esta, sem dúvida, a marca distintiva da pedagogia histórico-crítica. (SAVIANI, 2013, p. XVI; prefácio)
\end{abstract}

É com esse propósito que se somam as contribuições positivas de um número cada vez maior de estudiosos e pesquisas de diversas instituições do país para colaborar com o desenvolvimento da Pedagogia Histórico-Crítica. Embora o trabalho de Dermeval Saviani ${ }^{30}$ seja um marco fundamental dessa corrente pedagógica, há atualmente um movimento conjunto de extrair e explorar sua fecundidade por meio de abordagens e análises efetuadas de vários temas articulados a ela.

Como evidência concreta desse movimento, o Seminário Pedagogia históricocrítica: 30 anos, com ares de comemoração, é um balanço do atual estágio de desenvolvimento e da configuração da corrente através dos trabalhos apresentados. Ele ocorreu em dezembro de 2009, na Unesp de Araraquara, sendo realizado pela Comissão Organizadora formada por pessoas ligadas ao Grupo de Pesquisa "Estudos Marxistas em Educação" e ao Programa de Pós-Graduação em Educação Escolar da Unesp de Araraquara (SAVIANI, 2011).

Saviani (2011) explica que o seminário foi dividido em cinco eixos temáticos, distribuídos entre nove estudiosos ${ }^{31}$ que vêm se dedicando a eles: fundamentos da pedagogia histórico-crítica; pedagogia histórico-crítica e psicologia histórico-cultural; contribuições específicas à pedagogia histórico-crítica: educação infantil, formação moral e prática

\footnotetext{
${ }^{30}$ É esclarecedor notar em Saviani (2011) como este educador é estimulado a refletir sobre caminhos próprios partindo de proposições que ultrapassassem as pedagogias tradicional e escolanovista problematizando episódios da sua trajetória docente em 1967, como professor nos cursos colegial e normal e no ensino superior.

${ }^{31}$ Entre esses estudiosos figuram os seguintes nomes: Newton Duarte, Sandra Della Fonte, Lígia Márcia Martins, Juliana Camprengher Pasqualini, Juliane Zacharias Bueno, Ana Carolina Galvão, Marilda Gonçalves Dias Facci, Lidiane Teixeira Brasil e Sonia Mari Shima Barroco.
} 
pedagógica; a crítica às pedagogias do "aprender a aprender" como contribuição para a pedagogia histórico-crítica; pedagogia histórico-crítica e educação especial.

Muitas são as áreas mais específicas e, muitas vezes, pouco debatidas, sobre as quais a visão da Pedagogia Histórico-Crítica tem sido repousada com relação a aspectos de grande importância da problemática pedagógica. Sinais contundentes do seu aprimoramento e de sua postura compromissada com a realidade objetiva da práxis educativa, ou seja, expor as determinações essenciais das relações sociais que se ocultam sob os fenômenos educativos aparentes sujeitos à orientação político-ideológica capitalista.

\subsection{Contextualização teórica da Pedagogia Histórico-Crítica}

$\mathrm{Na}$ análise dos fundamentos teóricos da Pedagogia Histórico-Crítica é importante observar a influência e a contribuição do referencial marxista. É por essa orientação que Duarte (2011) e Della Fonte (2011) discutem esses fundamentos. Ambos os autores partem da perspectiva na qual o referencial teórico é central para a viabilização de uma revolução social.

Duarte (2011) trabalha com três eixos refletidos na sociedade comunista: a individualidade livre e universal, a autoatividade como atividade plena de sentido e as relações plenas de conteúdo. A individualidade é trabalhada por Marx como central na concepção marxista da sociedade comunista, primando pela liberdade do indivíduo.

Isso porque na coletividade comunista os indivíduos controlam as condições de existência, o que possibilita o livre desenvolvimento dos seres humanos, o que é bem diferente do desenvolvimento espontâneo que ocorre nas condições autonomizadas que na sociedade capitalista comandam a vida dos indivíduos à revelia de sua vontade e de sua consciência. (DUARTE, 2011, p. 13)

No capitalismo, com a mundialização das relações de mercado e com a autonomização das forças produtivas, os indivíduos passam a se relacionar pela mediação do valor de troca condicionando suas relações à ausência de todo conteúdo, o que converte os indivíduos a unilaterais, abstratos. A possibilidade de superação acontece pela apropriação total, pela humanidade despossuída dos meios de produção, da riqueza cultural, tanto espiritual quanto material. Na fronteira do conhecimento, isso significa que a apropriação a ser preconizada é do conhecimento socialmente produzido pela classe trabalhadora, implicando ainda os outros dois aspectos supracitados. Na sociabilidade comunista, o trabalho é a autoatividade dotada de sentido na qual o indivíduo desenvolve sua personalidade e através da qual ele deixa os rastros de sua individualidade na riqueza humana universal. Para 
alcançar um trabalho como atividade de autorrealização dos indivíduos, é imprescindível superar as circunstâncias de alienação do trabalho capitalista. $\mathrm{O}$ ato de trabalho, no modo de produção do capital, é meramente um meio para a existência material. A principal atividade da vida dos homens que preenche de sentido a existência do ser social é reduzida e alheia aos seres humanos.

\begin{abstract}
Vejam o que os seres humanos são obrigados a fazer na sociedade capitalista: para continuarem a viver precisam desfazer-se de uma parte de sua vida, precisam vendêla a outro e não vendem qualquer parte da sua vida, vendem a mais importante, que é precisamente sua atividade vital, aquela que permitiria seu desenvolvimento como ser genérico, como indivíduo conscientemente integrante do gênero humano. (DUARTE, 2011, p. 17)
\end{abstract}

O trabalho, na estrutura produtiva comunista, deixa de ser uma fonte da existência e passa a ser a condição para os indivíduos desenvolverem sua individualidade na mesma proporção do desenvolvimento das forças produtivas humanas. É uma atividade plena de sentido que permite que o indivíduo se desenvolva de maneira universal e livre. Uma decorrência disso, portanto, é a efetivação de relações humanas plenas de conteúdo nas quais os conteúdos objetivamente existentes da riqueza humana são transformados em conteúdos da subjetividade rica dos indivíduos. "Se a riqueza da individualidade depende das relações sociais das quais participa o indivíduo, então é claro que nossa individualidade é extremamente pobre na sociedade contemporânea, na qual as relações sociais são reduzidas a um único denominador comum: o dinheiro" (DUARTE, 2011, p. 18-19). É possível afirmar, então, que no comunismo a vida é plena de sentido e de conteúdo, e as relações de atuação recíprocas dos homens surgem realmente humanizadas.

As considerações de Della Fonte (2011) são acerca das acentuações teóricas ${ }^{32}$ julgadas por ela como necessárias para a luta ideológica contemporânea e que estão contempladas na Pedagogia Histórico-Crítica. Ela também destaca três pontos, entre outros ${ }^{33}$, que se mostram essenciais para a estruturação de uma concepção pedagógica que anseia um projeto educacional com abrangências revolucionárias, a saber: a realidade existe e é cognoscível, parte-se do entendimento de que o real é efetivamente existente em si e passível de ser conhecido apenas de modo aproximativo; objetividade não significa neutralidade $e$

\footnotetext{
32 Della Fonte (2011) cita dois outros trabalhos, Oliveira (1994) e Duarte (1994), que já sinalizaram sobre esse assunto tornando redundante o que ela apresenta em seu texto.

${ }^{33}$ Outros pontos que poderiam ser acrescentados como relevantes no debate teórico do momento são: “(...) a necessidade de preservar a tensão dialética entre teoria e prática contra esforços de diluir essas dimensões do fazer humano em uma identificação, a distinção da prática como critério de verdade e a prática imediata do pragmatismo, assim como a diferença entre a compreensão de linguagem no horizonte da sociabilidade humana e a linguagem vista como artefato autorreferente (...). (DELLA FONTE, 2011, p. 35; Grifos da autora)
} 
totalidade não é tudo, pois todo o existente é o impulso em direção à externalidade de si que ganha existência na malha de relações que o constituem em sua totalidade (ideia de que todas as coisas estão interligadas entre si) e processualidade histórica, cujo conhecimento é passível da interpenetração do agir interesseiro, não existe saber desinteressado; ser contra o relativismo cultural não é ser contra a multiplicidade da cultura, em que os chamados Estudos Culturais, Multiculturalismo e/ou Interculturalismo se posicionam como os únicos em defesa da diversidade da cultura humana, quando, no entanto, não defendem esta diversidade, mas o relativismo ontológico e o ceticismo epistemológico postulando a multiplicidade de verdades e rechaçando a pretensão de verdades universais.

Esses fundamentos abarcam simultaneamente tanto a dialética, a relação do movimento e das transformações, como também uma dialética do movimento do real. Dialética esta que possui um caráter histórico e se manifesta no materialismo histórico, “(...) que é justamente a concepção que procura compreender e explicar o todo desse processo, abrangendo desde a forma como são produzidas as relações sociais e suas condições de existência até a inserção da educação nesse processo" (SAVIANI, 2013, p. 120).

Nesse sentido, Saviani (2013) alega que procurou abordar os significados de práxis nas considerações de Sánchez Vázquez (1968) e na filosofia da práxis, tal como Gramsci concebia o marxismo. A noção de filosofia da práxis é estabelecida pelo suposto de uma teoria que é remetida à consubstanciação da teoria e da prática unificando-se na práxis. Conserva-se uma prioridade da prática em detrimento da teoria, uma vez que esta se apresenta como uma derivação. A explicitação da prática ocorre por meio de uma fundamentação teórica que a condiciona. Dito isso, torna-se sugestiva a questão do método ${ }^{34}$. A referência é, pois, ao método de Marx. E o que Saviani tem trabalhado está pautado no texto marxiano Método da economia política ${ }^{35}$, presente no livro Contribuição à crítica da economia política (1973). Dele, são tirados os pressupostos nos quais se baseou e tentou compreender o método pedagógico, girando em torno do movimento do conhecimento pela mediação do abstrato, desencadeando a passagem do empírico ao concreto. Ou ainda, pela mediação da análise, a passagem da síncrese à síntese. Isso coincide com o que Saviani coloca no processo pedagógico no qual há a explicitação da mediação por meio de três momentos chamados por ele de problematização, instrumentalização e catarse $^{36}$. No processo pedagógico, há a

\footnotetext{
${ }^{34}$ Conforme Saviani (2013), há um esboço dessa discussão na parte introdutória do seu livro Educação: do senso comum à consciência filosófica (1980 [17. ed., 2007]).

${ }^{35} \mathrm{O}$ conteúdo deste texto foi discutido no capítulo II.

${ }^{36}$ Saviani trata desse assunto no texto Escola e democracia II - para além da teoria da curvatura da vara (SAVIANI, 2007, p. 59-80).
} 
inserção da categoria mediação e, dessa forma, a educação é tida como uma mediação dentro da prática social global (SAVIANI, 2013).

Os fundamentos teóricos do materialismo histórico são usados para a explicação do método pedagógico. Ao aparecerem outras noções, como o conteúdo, o conhecimento e a ação do professor, exige-se a compreensão da problemática das relações sociais.

\begin{abstract}
Se a educação é mediação no seio da prática social global, e se a humanidade se desenvolve historicamente, isso significa que uma determinada geração herda da anterior um modo de produção com os respectivos meios de produção e relações de produção. E a nova geração, por sua vez, impõe-se a tarefa de desenvolver e transformar as relações herdadas das gerações anteriores e depende delas. Mas é uma determinação que não anula a sua iniciativa histórica, que se expressa justamente pelo desenvolvimento e pelas transformações que ela opera sobre a base das produções anteriores. (SAVIANI, 2013, p. 121)
\end{abstract}

Por conseguinte, como mediação no seio da prática social global, para a educação é reservado o papel de oportunizar que as novas gerações possam se apropriar daquilo que foi produzido precedentemente de maneira a lhes dar condições de agentes ativos na processualidade do desenvolvimento e transformação das relações sociais.

Saviani (2013) atenta para a exemplificação de alguns desdobramentos do método pedagógico designado na Pedagogia Histórico-Crítica. O primeiro é a diferença entre o aluno empírico e o aluno concreto. A distinção situada entre eles se mostra na medida em que o educando é posto a partir de sua realidade concreta no entendimento de concretude como síntese de múltiplas determinações decididas como relações sociais. A realidade colocada está no eixo de determinação de interesses dos alunos concretos que não foram escolhidos por eles e sim gerados nas condições em que eles se encontram, “(...) firmando-se o princípio de que o atendimento aos interesses dos alunos deve corresponder sempre aos interesses do aluno concreto" (Ibidem, p. 121). No que perpassa o conhecimento sistematizado, o domínio desse conhecimento pode não corresponder ao interesse do aluno empírico. Todavia, na condição de síntese de múltiplas determinações, o aluno está incluso num meio social que põe a exigência da apropriação desse tipo de conhecimento. Assim, de um lado, a educação precisa viabilizar o acesso a esse saber socialmente construído e, de outro, a mediação do professor. Tendo, por sua vez, apreendido as relações de forma sintética, é fundamental para que o aluno tenha o aprendizado alcançado.

A seguir, Saviani (2013) comenta a diferença nas relações do professor e do aluno com a sociedade e o processo educativo. De modo predominante, a relação do aluno se dá de forma sincrética e a do professor, de forma sintética. No processo pedagógico, a aproximação 
do aluno com o professor permite que ele também tenha uma relação sintética com o conhecimento da sociedade.

Há ainda a questão da relação conteúdo e forma, que se correlacionam. Numa concepção dialética, conteúdo e método estão conjugados. Na importância dos conteúdos, valoriza-se a necessidade de trabalhá-los em concreto, conteúdos em sua articulação com as formas. Colocando-se as disciplinas do currículo escolar, existem duas observações importantes. Primeiro, a relevância e a determinação dos conteúdos históricos pelos quais se apreende a perspectiva histórica, o modo de se situar historicamente. Segundo, a superação da fragmentação dos conteúdos como resultante de uma estrutura social centrada na divisão social do trabalho. Prima-se pela integração das diferentes disciplinas numa demarcação de totalidade, distinguindo-se seus constituintes numa visão sintética de conexões entre elas (SAVIANI, 2013).

O aporte teórico da Pedagogia Histórico-Crítica é fundado prioritariamente nos referenciais articulados a Marx, mais especificamente a partir da concepção do materialismo histórico. Saviani (2013) lança a importância da utilização dos clássicos para a possibilidade da elaboração de uma teoria pedagógica consistente somente em relação e com a presença deles interligados a outros clássicos da cultura, da filosofia e da pedagogia. Apenas a contribuição de Marx seria insuficiente para sustentar os apoios teóricos. Incluem-se aí também clássicos brasileiros, como, por exemplo, Fernando de Azevedo, Lourenço Filho, Anísio Teixeira e Paulo Freire. A advertência feita no que se refere a esses autores no Brasil é na direção de sanar a ignorância instalada acerca do conteúdo trazido por eles em suas produções.

Saviani (2013) distingue outras literaturas da área nas quais a Pedagogia HistóricoCrítica se baseia considerando pensadores que buscaram discutir os problemas pedagógicos em matrizes teóricas do materialismo histórico, ilustradas, especialmente, por Marx e Gramsci: Bogdan Suchodolski (1966, 1971, 1976, 1977 e 1984); Mario Alighiero Manacorda (1964, 1969 e 1974); e George Snyders (1974, 1976a, 1976b e 1986). Também aqueles mais localizados no âmbito da filosofia da educação, ele menciona autores da psicopedagogia, como membros da Escola de Vigotski, e da pedagogia, como Pistrak (1981), Makarenko (1977, 1982 e 1985), e de intérpretes das teorias pedagógicas de Gramsci, como Broccoli (1977), Betti (1981), Ragazzini (1978 e 2002) e o já referido Manacorda.

\subsection{A Pedagogia Histórico-Crítica e a formação humana}


Para se discutir as correlações possíveis da Pedagogia Histórico-Crítica acerca da formação humana, a linha de raciocínio segue a direção das relações entre a ontologia do ser social e a educação. Duarte (2012) lembra que o êxito dessa direção está necessariamente ligado à observância da obra de Saviani. Um estudo da educação que se pretende uma abordagem ontológica precisa estar caminhando no sentido de buscar a especificidade dessa esfera constitutiva do ser social. E é isso que esse autor faz, visto que ele trabalha com elementos para uma ontologia de educação. O trabalho de Saviani é bastante significativo no cenário educacional, tendo em vista sua pertinência teórica e política e o fato de contribuir para as tentativas de aproximação com as teorias lukacsianas referentes à ontologia do ser social que são pouco frequentes.

Para as teorias marxistas, um dos desafios é a formulação de uma ontologia da educação, pois ela

(...) adquire real significado como objeto de reflexão ontológica somente quando analisada como um dos complexos que compõem o ser da sociedade. Mas como o ser da sociedade é histórico, a essência ontológica da educação só pode ser apreendida numa perspectiva historicista. (DUARTE, 2012, p. 38)

A ontologia da educação deve compreender a essência historicamente construída pelo processo de formação dos indivíduos humanos como seres sociais. Coloca-se, portanto, a expectativa de considerar os processos historicamente concretos de formação dos homens. Através desses processos, vai se decidindo uma atividade humana específica para este fim e as possibilidades históricas do vir a ser da educação. Adota-se então a perspectiva historicista que perpassa o desenvolvimento humano como um processo contraditório, heterogêneo, que se processa pelas relações sociais de dominação características na história humana.

Duarte (2012) nota que um dos pilares básicos dos trabalhos de Saviani é exatamente a procura da sobrepujança da dualidade entre essência e historicidade. A essência da educação e do ato educativo passa a ser vista como um processo histórico. Ele analisa, além do processo pelo qual a educação escolar se tornou a forma dominante no capitalismo, o processo de desenvolvimento do significado ontológico do trabalho educativo. A princípio, uma forma de educação espontânea na qual as pessoas se educavam pelo trabalho para alcançar a forma escolar secundária e dependente. Como consequência das intensas alterações nas relações de produção material e na produção e apropriação do saber provocadas pelo capitalismo, houve a institucionalização da educação, uma necessidade social da educação para-si, deixando clara a interpenetração entre educação escolar e a organização societária. 
Tal institucionalização significa que a produção e reprodução do ser da sociedade passam, ao longo do processo histórico, a requerer a existência de um tipo específico de atividade humana, voltado para a formação dos indivíduos. Em outras palavras, a partir do capitalismo torna-se uma necessidade do ser da sociedade a elevação do processo educativo, do nível de processo educativo em-si para o nível de processo educativo para-si. (DUARTE, 2012, p. 44)

A atividade educativa é inerente ao desenvolvimento e à complexificação social atingida até então na sociedade capitalista. $\mathrm{O}$ avanço histórico-ontológico representado na educação escolar sinaliza a exigência das relações sociais pela especialização da atividade humana. Isso numa esfera da sociabilidade com especificidade, legalidade e contradições próprias, ainda mais porque é um componente que não pode ser extinguido da vida em sociedade por viabilizar que os homens se humanizem pela educação.

Outra contribuição de Saviani se refere a sua definição de trabalho educativo guiada pela concepção de trabalho na literatura marxiana.

\footnotetext{
(...) o trabalho educativo é o ato de produzir, direta e intencionalmente, em cada indivíduo singular, a humanidade que é produzida histórica e coletivamente pelo conjunto de homens. Assim, o objeto da educação diz respeito, de um lado, à identificação dos elementos culturais que precisam ser assimilados pelos indivíduos da espécie humana para que eles se tornem humanos $e$, de outro lado $e$ concomitantemente, à descoberta das formas mais adequadas para atingir esse objetivo. (SAVIANI, 2013, p. 13; Grifos meus)
}

Dessa definição, Duarte (2012) fala a respeito de três decorrências: 1) o trabalho educativo possui uma significação ontológica estabelecida por uma análise histórica e direciona tais análises para formas históricas concretas de humanização do ser social, a partir da essência constituída historicamente da educação na produção da humanidade nos homens pela dialética entre objetivação e apropriação; 2) a superação do conflito entre as pedagogias da essência e as pedagogias da existência; 3) o trabalho educativo é uma produção direta e intencional, uma atividade intencionalmente gerida por fins.

Não obstante, Saviani e Duarte (2012) escrevem que o tratamento dado pela Pedagogia Histórico-Crítica à formação humana toma a orientação da perspectiva históricoontológica contida nos Manuscritos econômico-filosóficos, de 1844, embora ela seja percebida em toda a produção intelectual de Marx.

A concepção de formação humana marxiana é explicada em seus delineamentos principais, visto que um posicionamento categórico sobre o que significa educar os seres humanos é assumido. Essa concepção articula e justifica coerentemente as pormenorizações 
abordadas, tanto na concepção marxista de homem quanto nos princípios ontológicos fundamentais de Marx. Em razão disso, os comentários mais importantes são feitos aqui com contornos sintéticos a fim de criar uma atmosfera propensa para se pensar a formação humana perspectivada pela Pedagogia Histórico-Crítica.

Da rica discussão trabalhada por Saviani e Duarte (2012), a ênfase está nas explicações pontuais acerca da formação humana, a partir do caminho tecido pelo autor na contramão literal dos processos (de) formativos da ordem burguesa. Não se pode ignorar o fato de que também, nessa ordem, os homens estão submetidos a uma formação específica, mesmo que ela seja alcançada pela mediação da alienação. Existe um projeto formativo capitalista em jogo no sentido de "dar forma" ao ser humano em processos, como, por exemplo, a "coisificação" do ser social, que converte a humanização em seu oposto. A ideia de deformação, por outro lado, tem natureza ideológica diante da negação dos impactos de desrealização dos homens nessas circunstâncias formativas alienante e alienada.

Saviani e Duarte (2012) conceituam a educação como formação do ser humano. A questão filosófica colocada está ligada ao problema da possibilidade, legitimidade, valor e limite das ações humanas, principalmente da educação, por meio do que consiste ser a formação humana. Esses quatro pontos são resolvidos pelo entendimento de que a educação é a promoção do homem, de ambos os agentes envolvidos - educador e educando, enquanto interação entre sujeitos livres em níveis distintos de "maturação humana", o que se refere, em termos de quantificação e qualificação, ao grau de apropriação das objetivações historicamente produzidas e acumuladas. A formação do ser social corresponde ao processo de promoção humana pelo efeito do ato de educar. Tão logo, em seu papel de determinar qual a identidade própria do seu objeto, a tarefa ${ }^{37}$ mais relevante da filosofia da educação é a vigilância crítica ao acompanhar de perto a atividade educacional (os fundamentos, a contribuição das diferentes disciplinas pedagógicas e o significado das soluções escolhidas).

Por essa vigilância crítica, uma importante atuação da filosofia da educação é a reflexão radical, rigorosa e de conjunto das problemáticas da realidade atual. O que está acentuada na situação do real existente é a crise de paradigmas entre a metafísica ${ }^{38}$ e uma filosofia histórica e historicizadora. O "inimigo" a ser combatido é o neopragmatismo, que, na

\footnotetext{
37 Saviani e Duarte (2012, p. 14-15) destacam outras responsabilidades da filosofia da educação: “(...) o esclarecimento das formas de abordagem, a referência aos clássicos, a diferenciação das concepções pedagógicas e a clareza conceitual e terminológica (...).

${ }^{38}$ Metafísica pode ser definida como um modo de filosofar exposto nesta passagem: “(...) o método de filosofar pode elidir a história ao fazer abstração de seu movimento concreto e convertê-la em ideias que se justificam por si mesmas, se movimentam de forma autônoma e, na sua formulação mais extrema, se convertem em geradoras do próprio mundo real" (SAVIANI; DUARTE, 2012, p. 16).
} 
tentativa de se opor à metafísica, acaba por ser profundamente metafísico, reduzindo tudo à linguagem, além de agrupar outras características do movimento da pós-modernidade. E a via estratégica de combate indica que "O antídoto ao modo metafísico de filosofar é a historicização, isto é, a concepção que toma a história não apenas como o conteúdo da filosofia, mas também como o seu método, ou seja, que unifica na história o conteúdo e a forma de filosofar" (SAVIANI; DUARTE, 2012, p. 16). Mais do que considerar a fertilidade dos aspectos históricos, esse filosofar é conduzido pelo método histórico para a disposição de suas produções cujo objeto de causa é a condição humana dos sujeitos históricos.

E é esse filosofar que Marx admite nos Manuscritos. O pressuposto é o de que o ser social coincide com um permanente processo de objetivação e “(...) a formação humana é analisada na relação entre o processo histórico de objetivação do gênero humano e a vida do indivíduo como ser social" (SAVIANI; DUARTE, 2012, p. 20). O que faz do indivíduo humano um ser genérico é sua atividade vital, cuja função é assegurar a vida de uma espécie. A atividade vital do homem é o trabalho, que se diferencia de outras atividades, porque, por sua qualificação teleológica, estabelece que a objetivação dos produtos os conduza a obter um valor de uso na prática social. Através de sua atividade vital, o ser humano assimila o caráter social dos fenômenos em sociedade de modo historicamente universalizador. Avançando sobre as necessidades naturais, as necessidades humanas se expandem para aquelas genuinamente sociais. A objetivação do ser social acontece, então, em sua atividade vital, que, neste ser, seu modelo básico é a transformação da natureza em propriedades dos objetos. Tem-se ainda que, pela construção da riqueza objetivamente desenvolvida na natureza humanizada, ao trabalhar, o homem condiciona a humanização de suas dimensões: a consciência, a sensibilidade, a personalidade, a sentimentalidade, a corporalidade, entre outras. Assim, a composição do mundo objetivo é a forma afirmativa do ser genérico e o produto do trabalho é a realização efetiva do sujeito que trabalha, a atividade transformada em objeto social (SAVIANI; DUARTE, 2012).

Com o passar da história social, marcada pelos conflitos de classes antagônicas, as relações de produção atuantes se desdobraram na divisão social do trabalho que ocasiona contradições entre a objetivação dos produtos sociais e a apropriação desses resultados pela totalidade social. Sendo assim, num certo sentido, outras divisões são operadas na fragmentação do conhecimento exigido para o trabalho, das atividades humanas, dos produtos sociais, das forças vistas do ser social, dos processos educativos oferecidos às classes sociais, etc. A classe beneficiada é a dominante e os produtos da atividade do trabalho são 
incorporados pelo interesse voltado à acumulação do capital, alienando esses produtos da classe que os produz.

Ocorre que não há outra maneira de o indivíduo formar-se e desenvolver-se como ser genérico senão pela dialética entre a apropriação da atividade humana objetivada no mundo da cultura (aqui entendida como tudo aquilo que o ser humano produz em termos materiais e não materiais) e a objetivação da individualidade por meio da atividade vital, isto é, o trabalho. (SAVIANI; DUARTE, 2012, p. 22)

O trabalhador não usufrui de suas produções na sociedade capitalista, visto que os produtos gerados por esse trabalhador são hostis, estranhos, alheios ao indivíduo que os produziu. Ele se vê privado das riquezas objetiva e subjetiva do seu trabalho, não podendo se apropriar delas plenamente. A principal forma de apropriação é a posse imediata dos objetos por meio do dinheiro, indicador fundante das trocas feitas entre os indivíduos sociais.

Nas pesquisas de Marx, o trabalho alienado se constitui como a desrealização do trabalhador que se vale apenas do que é necessário para sobreviver. Trabalhar é um simples meio de vida e a exclusiva forma de ser é aquela de força de trabalho nas relações de trabalho "escravo", particular, demasiadamente unilateral e automático, da ordem capitalista. O trabalhador e os produtos do seu trabalho figuram como mercadorias pertencentes ao capital. “(...) no ato da venda de sua força de trabalho, aliena-se da atividade que o formaria plenamente como ser humano e por meio do qual ele participaria conscientemente da formação de um mundo plenamente humano (...)" (SAVIANI; DUARTE, 2012, p. 28). Logo, sua individualidade não é expressa e a objetivação, via única pela qual o ser humano se efetiva e desenvolve, se torna alienante. A lógica do capital e da propriedade privada regula a "mercadorização" da vida genérica do ser social, "capitaliza" as relações humanas e destitui o trabalho de seu caráter humanizante. Passa a existir a perspectiva de deturpação da funcionalidade formativa do trabalho posto a serviço da realização do ser genérico e do desenvolvimento da individualidade do ser humano.

Segundo Saviani e Duarte (2012), para Marx, a superação da organização social burguesa não gira em torno da eliminação do ato de trabalho e nem da renúncia da riqueza produzida pelo trabalho alienado, tendo em vista que, apesar do que ocorre na etapa histórica capitalista $^{39}$, a generalidade humana continua sendo produzida e reproduzida pela

\footnotetext{
${ }^{39}$ No interior do processo histórico global não pode ser esquecida a "função humanizadora do capitalismo" na sua condição temporária de classe revolucionária no período do feudalismo. Depois de ter alcançado o poder, a burguesia se converteu ao conservadorismo e foi instalada a decadência ideológica do pensamento burguês após as revoluções de 1848, indicada nos estudos de Lukács (DUARTE, 2012).
} 
humanidade. O que se torna de fundamental importância é a seletividade do que aflui para o enriquecimento ou o empobrecimento do gênero humano.

\begin{abstract}
Ao longo do contraditório e heterogêneo processo histórico, o gênero humano tem se enriquecido, isto é, tem adquirido forças, faculdades e necessidades qualitativamente superiores, que passam a constituir parte ineliminável do ser da humanidade no seu conjunto, ainda que, em decorrência das relações alienadas, essas novas forças, faculdades e necessidades não se efetivem na vida da maioria dos indivíduos. Em outras palavras, é preciso distinguir aquilo que deva ser suprimido no processo de superação da lógica societária comandada pelo capital daquilo que, apesar de ter surgido no interior de relações sociais alienadas, deva ser preservado por uma sociedade socialista e elevado a um nível superior de desenvolvimento. (DUARTE, 2012, p. 39)
\end{abstract}

A alternativa insinuada é a transformação desse tipo de trabalho em autoatividade perante o fato de que “(...) o trabalho vem produzindo a universalidade da riqueza humana à custa da exploração da grande maioria de indivíduos" (DUARTE, 2012, p. 47). Para tanto, mudanças em quatro esferas da atividade humana são necessárias: “(...) a relação do sujeito com os resultados da atividade humana, a relação do sujeito com sua própria atividade, a relação do sujeito consigo mesmo como ser genérico, isto é, representante do gênero humano, e a relação do sujeito com outros sujeitos" (SAVIANI; DUARTE, 2012, p. 23). A ratificação da possibilidade do trabalho alienado leva ao comprometimento dessas esferas.

A expressão mais elaborada dessa superação se dá na sociabilidade comunista pela transformação das relações capitalistas de produção. Saviani e Duarte (2012) apontam as noções estruturais dessa organização social baseada no comunismo. $\mathrm{O}$ mundo resultante da objetivação passa a ser a confirmação da individualidade dos sujeitos e da essência universal do gênero humano. Muda-se radicalmente o processo de apropriação dos produtos da atividade humana na medida em que se alteram as relações dos seres sociais com o que já está presente na cultura e com os produtos gerados posteriormente. Somente através da riqueza objetivamente posta na realidade humana é que, na sua apropriação, o indivíduo se forma como um ser humano. Modificada também precisa ser a relação do sujeito com sua atividade, com o trabalho. Não apenas a satisfação de demandas do lado de fora do ambiente laborativo, mas uma atividade autorrealizadora, uma atividade livre e consciente. $\mathrm{O}$ trabalho se configura como primeira e fundamental necessidade do indivíduo perante sua carência de humanidade: é inelutável a necessidade de se realizar, de se exteriorizar, de se formar humano. Igualmente, está a necessidade de carecimento do seu semelhante, das individualidades de sujeitos que se relacionam pelo que existe de humano no outro. Dessa forma, o objetivo central é o alcance do pleno desenvolvimento da individualidade livre e universal. 
Saviani e Duarte (2012) trazem, então, que, para a apropriação da universalidade do gênero humano, o acesso aos clássicos é para as novas gerações a condição de sua plena humanização. Diferenciando o termo clássico, declara-se que não há uma equivalência ao tradicional e nem uma objeção ao moderno. Tradicional está associado ao passado, àquilo que é arcaico, algo ultrapassado. Moderno se refere ao tempo atual, aquilo que é contemporâneo, frequentemente ligado à ideia de avançado. "Em contrapartida, clássico é aquilo que resistiu ao tempo, tendo uma validade que extrapola o momento em que foi formulado. Define-se, pois, pelas noções de permanência e referência" (Ibidem, p. 31). Alguns filósofos da História são tidos como clássicos, porque suas teorizações possuem legitimidade histórica ao conservar sua viabilidade explicativa em relação às grandes problemáticas encontradas nas respectivas etapas de desenvolvimento da humanidade. Como via de acesso importantíssima, o estudo crítico desses filósofos tem significativo valor educativo, “(...) já que a educação não é outra coisa senão o processo por meio do qual se constitui em cada indivíduo a universalidade própria do gênero humano" (Ibidem, p. 31).

\footnotetext{
Por esse caminho a pedagogia ganha condições de assumir a perspectiva ontológica, apreendendo a educação, isto é, o processo de formação humana, como o contínuo movimento de apropriação das objetivações humanas produzidas ao longo da história. Eis como a filosofia estará concorrendo, na educação, para, a partir das relações alienadas, abolir os entraves que a forma social capitalista vem impondo ao desenvolvimento plenamente livre e universal do ser humano e de sua formação. (DUARTE, 2012, p. 34)
}

A Pedagogia Histórico-Crítica, ao se estabelecer nos fundamentos ontológicos do ser social, potencializa tanto a dimensão humanizadora do trabalho educativo como também o vir a ser da educação na mediação, no plano ontológico do processo de emancipação humana. 


\section{CAPÍTULO IV - CONSIDERAÇÕES FINAIS}

A pretensão deste percurso investigativo necessita ser recuperada a fim de encaminharmos a finalização do trabalho. Tratou-se de um primeiro contato com os estudos ontológicos do ser social para futuras incursões da/na Educação Física com proximidade às teorizações lukacsianas. Não estão postas discussões aprofundadas a fim de se esgotarem as contribuições da ontologia do ser social para essa área.

É um ponto de partida para a incorporação de teorias ontológicas que melhor explicassem as determinações do que o homem é e de como ele se constitui como ser da esfera da sociabilidade, um conhecimento necessário dos sujeitos da formação. Essa explicação se dá através de princípios metodológicos e de categorias que dão materialidade ao movimento real do ser social, como, no caso, a importância ontológica da categoria trabalho.

Não se sugere apenas a pertinência dos referenciais teóricos de Marx e Lukács. É algo mais radical. Para o que se propõe esta investigação, uma reflexão crítica que tem como objeto "processos formativos", está colocada a impossibilidade de pensá-los sem uma devida amarração fundada nesses autores. Uma profunda compreensão sobre o processo de formação humana na contemporaneidade exige a presença desses pensadores. Certamente, eles são insuficientes, mas sem eles não seria possível uma aprofundada compreensão.

A apropriação desses fundamentos torna possível definir os meios e as finalidades de determinado tipo de formação do indivíduo humano, sobretudo no que diz respeito a uma formação com vínculos, num projeto social maior e com aspirações emancipatórias. A compreensão de formação humana, na qual está a base dos fundamentos ontológicos estabelecidos por esta pesquisa, justifica-se coerentemente nas pormenorizações abordadas, tanto na concepção marxista de homem quanto nos princípios ontológicos fundamentais de Marx. Assim sendo, sinalizam-se algumas articulações que podem ser realizadas com a Educação Física e que, em outros momentos, precisam ser observadas com mais rigor e densidade.

Não há a ilusão de que, no solo da ontologia, tudo fique esclarecido e decidido. A tese é que nesse solo fértil existem possibilidades tangíveis de superação das barreiras sociais colocadas pelos próprios homens, quando da efetivação de forças e potências humanas no processo histórico de desenvolvimento do gênero humano. No plano ontológico, está a raiz da capacidade afirmativa do homem de intervir e modificar suas condições objetivas de existência, revelando como ele se mostra na processualidade histórica. É nisso que a 
Educação Física deve pautar sua atuação, bem como suas possibilidades de contribuição para o processo formativo dos indivíduos.

Nesse anseio de trazer essa compreensão ontológica do ser - que sempre repõe a possibilidade da emancipação humana - e mediá-la com o ensino - como um processo intencional de intervenção sobre a maneira de ser dos indivíduos - a Pedagogia HistóricoCrítica serve como uma lente pela qual a Educação Física poderia/deveria olhar. Tal pedagogia, no debate educacional brasileiro, é a mais eloquente proposta educacional sistematizada e representa uma tentativa de assimilação (e mediação com) da ontologia do ser social.

As parcas sinalizações, aqui consignadas, são as primeiras sínteses construídas pela trilha deixada por essa pedagogia. Tal trilha sugere alguns pontos de atenção, nos quais os processos formativos, em seus diferentes níveis, precisam se debruçar tendo como suposto orientador que o trabalho educativo realizado pela Educação Física é parte constituinte da formação humana.

Inicialmente, coloca-se o entendimento da delimitação das fronteiras do que vem a ser o complexo da Educação Física e do tipo de mediação que ele exerce na sociabilidade humana. Como um complexo surgido em função de necessidades propriamente sociais, este entendimento deve ir além de uma simples significação de educação do corpo, quando, na verdade, trata-se da educação de homens. Ou seja, um primeiro resultado do nosso estudo foi a indicação da necessidade de superarmos essa compreensão presente de que cuidamos, em nosso ato educativo, de corpos!

Exige-se, portanto, uma abordagem ontológica que prime pela tentativa de se descobrir a especificidade dessa particularidade constitutiva do ser social. Com efeito, por uma visão totalizante implica, entre outras coisas, uma apreensão autêntica dos pressupostos ontológicos da Educação Física e indica a análise histórica da dimensão do homem respectiva a sua natureza corporal.

\footnotetext{
Ao conjunto de práticas corporais do homem, sua expressão criativa, seu reconhecimento consciente e sua possibilidade de comunicação e interação na busca da humanização das relações dos homens entre si e com a natureza estamos chamando de corporalidade. A corporalidade se consubstancia na prática social a partir das relações de linguagem, poder e trabalho, estruturantes da sociedade. (OLIVEIRA, 1999, p. 40 apud OLIVEIRA, 2006, p.13-14; Grifo do autor)
}

Como um complexo particular componente do ser da sociedade, a Educação Física pode ser investigada por compreender os processos historicamente concretos das objetivações 
humanas acumuladas relativas à corporalidade. A constituição e o desenvolvimento da corporalidade estão preponderantemente imbricados no processo de humanização como também outras dimensões que necessitam qualificar-se de humanidade. Sua consubstanciação na prática social ligada a eixos estruturantes do meio societário apresenta alguns determinantes. Apesar da linguagem e do poder serem elementos cruciais, as relações de trabalho têm uma prevalência ontológica, tendo em vista seu caráter humanizante e sua sujeição à estrutura produtiva, o que acarreta diferentes modos de educação do corpo. Nesse sentido, uma importante problematização parte da identificação de como e em que medida a corporalidade contribui para o processo de adequação ao gênero humano. Para os processos formativos, esta parece ser a questão mais decisiva.

Conforme alega Duarte (2012), é na relação entre essência e historicidade que aqueles pressupostos devem ser analisados. Por esta relação, observa-se que, na dinâmica entre a complexificação da organização social e as demandas surgidas para a sua reprodução, o avanço histórico-ontológico da Educação Física culmina com sua institucionalização, acompanhando o que se perpassa com a educação. Isso, em certo alcance, representa o que tende ser um movimento comum para diferentes complexos dos homens com o desenvolvimento da sociabilidade em formações mais complexas e sofisticadas, dando-lhes legitimidade e um poder maior de intervenção. No âmbito da Educação Física, é possível perceber isso, por exemplo, com os desdobramentos originados com os sistemas ginásticos europeus até a criação de cursos superiores, o ensino da Educação Física como disciplina obrigatória nos currículos escolar e universitário, o esporte institucionalizado (BRACHT, 1999; COLETIVO DE AUTORES, 2009; SOARES, 2000, 2006). Ao se diferenciar como uma esfera autônoma que se mantém numa ininterrupta troca dialética com outras do ser social, o uso de uma perspectiva historicista é importantíssimo no sentido de capturar por quais impulsos o em-si da Educação Física está sendo condicionado para o seu para-si.

Como uma forma determinada de educação que lida com parte da universalidade própria da generalidade humana, a Educação Física é interpenetrada pelo significado ontológico do ato educativo. Pondo isso no horizonte formativo, a noção apontada é de “(...) uma prática pedagógica que, no âmbito escolar, tematiza formas de atividades expressivas corporais, como jogo, esporte, dança e ginástica, formas estas que configuram uma área de conhecimento que podemos chamar de cultura corporal" (COLETIVO DE AUTORES, 2009, p. 50; Grifos meus). Embora essa seja uma noção concernente à educação escolarizada no trato de atividades corporais institucionalizadas, há de se considerar ainda esse exercício 
pedagógico em outros espaços, como academias, escolinhas esportivas, clubes, empresas, hospitais, entre outros, pelo professor de Educação Física.

Por essa concepção, tem-se a ideia de uma prática pedagógica que põe em execução a seleção, a organização e a sistematização lógica e metodológica de determinados conhecimentos e práticas a serem aprendidas pelos indivíduos. Isso remete à incorporação dos fundamentos ontológicos do ser social em seus processos formativos, visto que a intenção do trabalho educativo deve caminhar no sentido de criar as condições mais adequadas para que a relação dialética entre produção e apropriação possa se efetivar na identificação dos elementos culturais necessários à promoção da humanidade produzida histórica e coletivamente pelos homens. Além disso, devem-se buscar as formas e os métodos para se alcançar essa intenção. Sobre isso, Saviani e Duarte (2012) apontam para o valor educativo do que é clássico. Cabe, assim, o questionamento do que é clássico dentro do universo da corporalidade e quais elementos devem ser considerados pela cultura corporal, percebendo seus limites e possibilidades, na riqueza objetivamente construída na natureza corporal humanizada.

Certamente, inúmeras outras mediações e questões poderiam ser problematizadas, mas foi até aqui que chegamos. Parece-nos que, ao final do nosso estudo, temos como resultado um ponto de partida.

Esta dissertação é, pois, o relatório de nossos estudos. Partimos de uma proposta inicial que era a de analisar a produção sobre educação corporal, mas os estudos empreendidos nos demonstraram que, antes disso, havia a necessidade de uma discussão sobre o que é o corpo. Ora, pareceu-nos que a questão estaria mais bem colocada nos seguintes termos: o que é o homem?

Essa questão nos colocou a necessidade de estudarmos a concepção marxista de homem. Então percebemos, neste processo, que essa questão - o que é o homem? - exige uma abordagem ontológica: o que os seres são?

Seguimos, assim, nossa trilha investigativa, tentando uma apropriação, mesmo que inicial, do autor da tradição marxista que mais tratou dessa questão, Lukács. Nosso segundo capítulo é resultado deste nosso esforço investigativo.

Como nossa intenção era o retorno à questão sobre o corpo e as possibilidades educativas da educação física, coube-nos seguir a investigação tratando da educação sistematizada a partir de Marx e da ontologia. Por essa razão, envidamos nosso esforço investigativo acerca dos fundamentos e da proposta da Pedagogia Histórico-Crítica. 
No retorno à questão da educação do corpo, percebemos que toda a compreensão havia se modificado. Notamos que a possível contribuição da educação física, num processo educativo sistematizado, entre outras coisas, está debitada a capacidade de seus intelectuais superarem o debate centrado no corpo. Necessitamos, urgentemente, substituir o centro do debate pelo homem. E, para isso, percebemos que Marx, Lukács e a Pedagogia HistóricoCrítica são absolutamente necessários.

De nossa parte, ao final deste processo investigativo, temos um novo ponto de partida. Certamente, depois deste processo, temos condições, agora, de retomar às questões iniciais que mobilizaram nossa energia investigativa.

Já à Educação Física, está colocado o desafio de repensar a si mesma no sentido de colaborar para o desenvolvimento de singularidades enriquecidas no processo de formação humana. 


\section{REFERÊNCIAS}

BRACHT, Valter. A constituição das teorias pedagógicas da educação física. Caderno CEDES, Campinas, vol. 19, n. 48, ago./1999, p. 69-88.

COLETIVO DE AUTORES. Metodologia do ensino da educação física. 2. ed. rev. São Paulo: Cortez, 2009.

COSTA, Frederico Jorge Ferreira. A natureza ontológica do pensamento de Marx. In: Revista Eletrônica Arma da Crítica, n. 1, ano 1, jan./2009. Disponível em: <http://www.armadacritica.ufc.br/phocadownload/fredcosta.pdf $>$. Acesso em: 12 mar. 2015.

DELLA FONTE, Sandra Soares. Fundamentos teóricos da pedagogia histórico-crítica. In: MARSIGLIA, Ana Carolina Galvão. (Org.). Pedagogia histórico-crítica: 30 anos. Campinas: Autores Associados, 2011. p. 24-42.

DUARTE, Newton. Sociedade do conhecimento ou sociedade das ilusões?: quatro ensaios crítico-dialéticos em filosofia da educação. Campinas: Autores Associados, 2008. p. 05-38. (Coleção Polêmicas do Nosso Tempo, 86).

O debate contemporâneo das teorias pedagógicas. In: MARTINS, Lígia Martins; DUARTE, Newton. Formação de Professores: limites contemporâneos e alternativas necessárias. São Paulo, Cultura Acadêmica, 2010. p. 33-49.

Fundamentos da pedagogia histórico-crítica: a formação do ser humano na sociedade comunista como referência para a educação contemporânea. In: MARSIGLIA, Ana Carolina Galvão. (Org.). Pedagogia histórico-crítica: 30 anos. Campinas: Autores Associados, 2011. p. 07-21.

Lukács e Saviani: a ontologia do ser social e a perspectiva histórico-ontológica. In: SAVIANI, Dermeval; DUARTE, Newton (Orgs.). Pedagogia histórico-crítica e luta de classes na educação escolar. Campinas: Autores Associados, 2012. p. 37-57. (Coleção Polêmicas do Nosso Tempo).

FRIGOTTO, Gaudêncio. O enfoque da dialética materialista histórica da pesquisa educacional. In: FAZENDA, Ivani. (Org.) Metodologia da pesquisa educacional. 9. ed. São Paulo: Cortez, 2004. p. 69-90.

FROMM, Erich. Conceito marxista de homem. Tradução de Octavio Alves Velho. 6. ed. Rio de Janeiro: Zahar Editores, 1975.

HÚNGARO, Edson Marcelo. A constituição da teoria social de Marx: a trajetória intelectual de 1843 a 1857/58. In: HÚNGARO, Edson Marcelo. Trabalho, tempo livre e emancipação humana: Os determinantes ontológicos das políticas sociais de lazer. 2008. Tese (Doutorado em Educação) - Faculdade de Educação, Campinas. p. 21-95.

LESSA, Sérgio. A centralidade ontológica do trabalho em Lukács. Serviço Social \& Sociedade. São Paulo: Cortez, ano XVII, n. 52, dez./1996. p. 07-23.

Para compreender a Ontologia de Lukács. Ijuí: Editora Ijuí, 2012. 
LUKÁCS, Gyorgy. As bases ontológicas do pensamento e da atividade do homem. Temas de Ciências Humanas, São Paulo, n. 4, 1978. p. 01-20.

Meu caminho para Marx. In: Verinotio - Revista on-line de educação e ciências humanas: Espaço de interlocução em ciências humanas, n. 12, ano VI, out./2010. Disponível em: 〈http://www.verinotio.org/conteudo/0.69454763056203.pdf>. Acesso em: 12 mar. 2015.

Os princípios ontológicos fundamentais de Marx. In: LUKÁCS, Gyorgy. Para uma ontologia do ser social I. São Paulo: Boitempo, 2012. p. 281-422. 41-137.

O trabalho. In: Para uma Ontologia do Ser Social II. São Paulo: Boitempo, 2013.p.

MARX, Karl. Terceiro manuscrito. In: Manuscritos econômico-filosóficos e outros escritos. São Paulo: Abril Cultural, 1974. p. 07-54. (Os Pensadores).

Processo de trabalho e processo de valorização. Capítulo 5. In.: MARX, Karl. O Capital. 3. ed. São Paulo: Nova Cultural, 1988. p. 142-156.

; ENGELS, Frederich. A ideologia alemã (Feurbach). 11. ed. São Paulo: Hucitec, 1999.

. Trabalho estranhado (extrato). Ideias, Campinas, 9 (2)/10 (1), 2002-2003. p. 455-472.

Uma Introdução para a Crítica da Economia Política. Disponível em: <http://www.histedbr.fe.unicamp.br/acer_fontes/acer_marx/tme_15.pdf>. Acesso em: 12 mar. 2015.

OLDRINI, Guido. Em busca das raízes da ontologia (marxista) de Lukács. In: Para uma Ontologia do Ser Social II. São Paulo: Boitempo, 2013. p. 09-37.

OLIVEIRA, Marco Aurélio Taborda de. Prefácio. In: OLIVEIRA, Marco Aurélio Taborda de. Educação do Corpo na Escola Brasileira. Campinas, SP: Autores Associados, 2006. p. IXXIV. (Coleção Educação Física e Esportes).

PAULO NETTO, José. Introdução: Lukács - tempo e modo. In: LUKÁCS, György. Georg Lukács: Sociologia. PAULO NETTO, José. (Org.). São Paulo: Ática, 1981. p. 07-56.

; BRAZ, Marcelo. Capítulo 1. Trabalho, sociedade e valor. In.: PAULO NETTO, José; BRAZ, Marcelo. Economia Política: uma introdução crítica. 2. ed. São Paulo: Cortez, 2007.

Introdução ao estudo do método em Marx. São Paulo: Expressão Popular, 2011.

SCHAFF, Adam. O marxismo e o indivíduo. Tradução de Heidrun Mendes da Silva. Rio de Janeiro: Civilização Brasileira, 1967. p. 01-182.

SAVIANI, Dermeval. As concepções pedagógicas na história da educação brasileira. Campinas, UNICAMP, Projeto "20 anos do HISTEDBR”, 2005. 
DUARTE, Newton. (Orgs.). Pedagogia histórico-crítica e luta de classes na educação escolar. Campinas: Autores Associados, 2012. (Coleção Polêmicas do Nosso Tempo).

DUARTE, Newton. A formação humana na perspectiva histórico-ontológica. In: SAVIANI, Dermeval; DUARTE, Newton. (Orgs.). Pedagogia histórico-crítica e luta de classes na educação escolar. Campinas: Autores Associados, 2012. p. 13-35. (Coleção Polêmicas do Nosso Tempo).

Debate sobre educação, formação humana e ontologia a partir da questão do método dialético. In: MARSIGLIA, Ana Carolina Galvão. (Org.). Pedagogia histórico-crítica: 30 anos. Campinas: Autores Associados, 2012. p. 121-147.

- Antecedentes, origem e desenvolvimento da pedagogia histórico-crítica. In: MARSIGLIA, Ana Carolina Galvão. (Org.). Pedagogia histórico-crítica: 30 anos. Campinas: Autores Associados, 2012. p. 197-225.

Pedagogia histórico-crítica: primeiras aproximações. 11. ed. rev. Campinas: Autores Associados, 2013.

SILVA, Marcelo Lira. O estatuto ontológico em Lukács: a centralidade da categoria trabalho. Disponível em:

<http://www.estudosdotrabalho.org/anais6seminariodotrabalho/marceloliradasilva.pdf >. Acesso em: 25 maio 2014.

SOARES, Carmem Lúcia. Notas sobre a educação no corpo. In: Revista Educar. Curitiba: UFPR, n. 16, 2000. p. 43-60.

Corpo, conhecimento e educação: Notas esparsas. In: SOARES, Carmem Lúcia. (Org.). Corpo e história. 3. ed. Campinas, SP: Autores Associados, 2006. p. 109-129. (Coleção Educação Contemporânea). 